\title{
RURAL REHABILITATION AND URBAN SOCIAL PROGRAM IN NORTHERN AFGHANISTAN
}

\section{Proposal \\ March, 98}

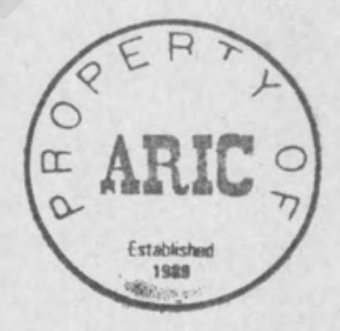

Submitted to: UNOCHA

Submitted by: DHSA 


\section{RURAL REHABILITATION AND URBAN SOCIAL PROGRAM IN NORTHERN AFGHANISTAN}

\section{Proposal \\ March, 98}

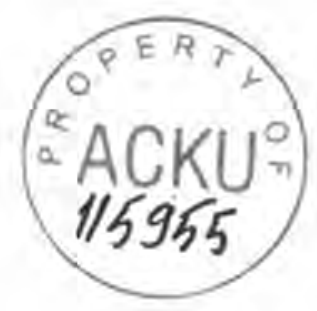

Submitted to: UNOCHA

Submitted by: DHSA 


\section{Summary Sheet}

Project Title: $\quad$ RURAL REHABILITATION AND URBAN SOCIAL PROGRAM IN NORTHERN AFGHANISTAN

Submitting Agency: Development and ; tumanitarian Services for Afghanistan (DHSA)

Contact Person: Shahir Zahine, Director or Dr. Raz M. Wali, Program Coordinator, DHSA

House \# 95, St. 6, N3, Phase 4, Hayatabad, Peshawar

Phone: 0092-91-817387, 814401

Fax: 0092-391-290 908

E.mail:saphir@dhsa.psw.erum.com.pk

Project Area: Mazar City and 3 Districts in Balkh Province (Balkh. Dawlatabad and Khulm)

Starting Date: $\quad 1^{\text {st }}$ April, 1998

Project Duration: 18 months

Overall Objective: To enhance the capacity of the target area to absorb returnees and IDPs and to stabilize the local settled population by:

- increasing food security

- increasing overall level of economic and self sufficiency

- improving health standards

- rehabilitating and developing rural infrastructures

through encouraging community participation in identifying problems, planning and implementing solutions.

\section{Sectoral Objectives:}

\section{WATER SUPPLY AND SANITATION}

\subsection{Wells and Hand Pumps}

To reduce the incidence of water borne disease among approximately 2,500 families by providing 100 wells cleaned and equipped with hand pumps.

\subsection{Surface Latrines}

To reduce the incidence of transmitting diseases and to manage the human wastes by constructing 200 Surface Latrines benefiting 200 families 


\section{RURAL INFRASTRUCTURE}

\subsection{Community Buildings}

To build 2 primary school buildings in the target area to provide educational opportunity for approximately 1000 students annually.

\subsection{Roads, Bridges and Culverts}

To construct 6 Small Bridges and 11 culverts for access improvement and the protection of irrigation systems, which benefiting 7.500 families.

\section{AGRICULTURE}

\subsection{Nursery Establishment}

To plant 1 ha of nurseries which will provide about 85,000 appropriate saplings for distribution in the target areas to re-establish orchards for approximately 1,050 farming families.

\section{SOCIAL WELFARE}

\subsection{Ashiana (Street Children)}

To gather primary data about the Street Children of Mazar City on which to base comprehensive programs while providing services to a limited number of 80 Street Children.

BUDGET:

Total US\$ 423,000 


\section{RURAL REHABILITATION AND URBAN SOCIAL PROGRAM IN NORTHERN AFGHANISTAN}

\section{Background}

\section{A. Target Area}

The geographical reach of this proposal covers Mazar City and 3 districts of Balkh Province (Balkh, Dawlatabad and Khulm). The districts are essentially rural in nature and the projects envisioned include Water Supply and Sanitation (Wells equipped with Hand Pumps and Surface Latrine Construction), Agriculture (Nursery Establishment), Rural Infrastructure (Road Repair, Bridge/Culvert Construction and Community Building Construction) and Social Welfare (Ashiana, Street Children Program).

Mazar-e-Sharif city is laid out in great pattern of Holy Shrine of Hazrat All and the blue mosque in the center. It is the second major city in the country. Its main attitude is 360 meter from the sea level land area is $48 \mathrm{sq} . \mathrm{km}$. Its basic population in 1990 was around 130,000 persons. The main economic activity are trade and services. Major ethnic group are Tajik, Pashtun, Uzbeks, Hazara and Sadats. 20\% of road are primary asphalt. Balkh television station commenced operation in 1987 and its telecast are effective within a radius of $25 \mathrm{~km}$. A daily newspaper is published in Pashtu and Dari and an Uzbek newspaper is published weekly. There is a water supply network in Mazar-e-Sharif that is supposed to provide 15 It. water per person per day but due to lack of maintenance and poor management it can not meet the requirement. The newly constructed area of the city by the IDPs and local people are suffered from shortage of potable and running water. Education facilities are limited and inadequate. Existing schools suffer from shortage of teaching materials and limited number of qualified teacher as the local government does not pay the teachers and other educational staff. Health status in Mazar city is under developed and the main hospitals in the city are not well equipped and qualified staff and medicine are limited Most of the people are using unspecialized clinics

Balkh District is about $24 \mathrm{~km}$ northwest of Mazar-i-Sharif in Balkh Province. It lies on a plain at a mean altitude of $340 \mathrm{~m}$ above sea level. Much of the land in the district is fertile when water is available. The Balkhab River supplies water to irrigation canals in the district. Wheat is the major crop in the region and cotton is also important. Other important crops include melons, apples, grapes and pomegranates. Carpet weaving and pottery making constitute the only other significant economic activities in the District. Secondary roads in much of the District are in bad repair although a primary road north to Dawlatabad has been improved in recent years. There is no sewerage system in Balkh District. Residents of Balkh city get their water from 12 standpipes located about the city served by a deep bore well and reservoir. The rest of the district must obtain its household water from irrigation canals. Population is estimated at approximately 101,270 persons. The primary ethnic group in the District is Pashtun.

Dawlatabad District lies directly to the north of Balkh District. It sits on a very flat 
plain with a mean altitude of $315 \mathrm{~m}$ above sea level. Estimates indicate that 156,000 ha are irrigable but only about $40 \%$ of this land is irrigated due to damage and lack of maintenance in the canal system. Wheat is of primary importance in the agricultural sector with cotton, melons and grapes also of importance. Animal husbandry, primarily sheep, are also important agricultural activities. The primary road from Balkh north to Dawlatabad center has recently been improved but secondary roads are in a state of almost total disrepair. There is no sewerage system anywhere in the district and household water is generally obtained from irrigation canals and open wells. The population is over 108,100 with Uzbek and Turkman the primary ethnic groups. The area also is the home of some Hazara, Pashtun and Tajik people as well.

Khulm District lies to the east of Mazar-i-Sharif and is served by a good hard surface road connecting it to Mazar in the west and Pul-e-Khumri in the east. The District has a mean altitude of $420 \mathrm{~m}$ above sea level about equally divided between a desert plain in the northeast and mountains in the southwest. The major crop is wheat but there are significant orchards and vineyards in the District as well. Pottery and tile making are the only other significant economic activities at present. The primary road is in reasonable repair but secondary roads in the District are severely damaged and have lacked maintenance for a long time. The population of the District is estimated at over 75,360 with Tajik and Pashtun as the dominant ethnic groups.

The districts of Balkh province selected for this project have been a primary destination for IDPs from Kabul and North Hazarajat. For the last twenty years, Balkh has been on the periphery of the serious fighting. But during the time of the Russian occupation there was heavy bombing and serious damage to infrastructure, most of which has not been repaired. Until recently the area has been comparatively peaceful and people have moved there from more disturbed areas. The area has excellent potential for absorbing further IDPs and returnees. In the present situation, access to the Hazarajat is easier from Balkh province than from most other areas of the country and provides a further motive for working there

\section{B. Development and Humanitarian Services for Afghanistan (DHSA)}

DHSA was established in 1992 by a group of Afghans of various origins and skills to encourage repatriation to rural areas by rehabilitating the local infrastructure, enhancing the overall level of economic self sufficiency, improving the health of people in the region, increasing educational opportunities and building the local capacity to identify problems and implement solutions independently. Where and when necessary DHSA has been involved in substantial emergency assistance efforts but its primary focus has always been on long term development and sustainability of the efforts.

The Main Office was originally established in Kabul with a Representation Office in Peshawar to maintain contact with donor agencies and coordinate with other NGOs In 1996 the Main Office was moved to Peshawar because of security concerns. A Regional Office is still maintained in Kabul and Field Offices exist in Ghazni, Mazar and Bamyan. 
Partnership and cooperation have been primary emphases throughout DHSA history. Shared offices, shared expertise and coordinated activity in the field have been pursued vigorously. DHSA has entered into partnership arrangements and shares offices with two other Afghan NGOs. DHSA has also shown itself capable and reliable in implementing projects in behalf of EU, UN $A S A A$, and other international donor agencies, both private and governmental.

\section{General Implementation Strategy}

The overall goal of DHSA is to stabilize the population of the target area by improving food security and enhancing agricultural production, health and economic status. This will contribute attract and facilitate repatriation of refugees and IDPS. Successful intervention in these sectors improves the capacity of the target area to absorb returnees and enhances the living conditions of the settled population. The primary strategies used in this effort are rehabilitating irrigation systems, providing improved wheat seed, distributing fruit tree saplings, improving roads, cleaning wells, installing hand pumps, developing vocational training programs and directing health education programs in conjunction with other programs.

In cooperation with local Shuras and other community representatives and using Participatory Rural Appraisal (PRA) techniques, DHSA identifies problems which the local people face. Solutions are devised and specific high impact projects are proposed with the cooperation and involvement of the local population. DHSA also makes a strong effort to be aware of any other NGOs or UNOs working in the same region in order to avoid duplication of effort and to cooperate with them. This improves the impact of all projects in the target area. DHSA's active effort to involve both the local community and other agencies active in the area allows all the interested parties to participate in selecting, prioritizing, planning, designing, implementing, monitoring and evaluating the projects

The projects selected and proposed emphasize the needs of returnees while enhancing the lives of the settled population. Economic opportunity is provided by employing both returnees and local residents in construction work and long term maintenance of projects. At the same time DHSA seeks to strengthen and enhance private economic activity in the target areas by purchasing materials and leasing equipment from the local markets wherever possible. DHSA seeks to concentrate its efforts in limited regions in order to increase the impact of the projects and to improve the ability of the agency to monitor and supervise the activities. Collaboration and cooperation with other agencies is a prime concern of DHSA as it plans its projects. Building of staff capacity is also of major importance and DHSA provides training and close supervision to achieve this end. 


\section{Survey:}

Needs assessments are performed and precise technical surveys are undertaken for each specific project in the presence of and in cooperation with local Shuras and other community representatives. Engineering projects are designed using the AutoCAD system and other advanced computer tools. Indicators of success and goals are agreed upon during these surveys and assessments. This contributes to smooth implementation, efficient use of resources and the ability to monitor progress by the community, the agency or the donor.

\section{Monitoring, Cost Control and Evaluation:}

Regular internal monitoring and evaluation are a part of the planned activity of all projects. Local field staff and departmental staff from the main office consult regularly to improve methodology and cost control. During the life of the project third party evaluations are planned in order to provide outside critiques by disinterested parties which can point out weak points and make suggestions for improvements in implementation. DHSA does impact analysis and project evaluation during the life of the projects in order to direct and sharpen future plans of the agency.

\section{Financial Management:}

Although DHSA is an implementing agency and is largely dependent on donor agencies for financing its projects and programs, this agency also generates some funds of its own through the income generating activities. Community participation takes the form of contributions of labor and materials when these are possible Funds generated from the subsidized sale of various commodities are used to create revolving funds to sustain and enhance program activities. Such funds are accounted for in planning, assessment and appraisal of future programs.

The fiscal year runs $1^{\text {st }}$ January through December $31^{\text {st }}$. A budget plan is prepared for activities of the organization. Funds are advanced to the field offices for implementation of the projects along with plans indicating the activities, allocation of funds and a time schedule for completion of specific tasks. At the field offices transactions are recorded in a complete set of account books using the double entry bookkeeping system. Field offices submit financial reports to the central office on a monthly basis. The central office maintains a set of financial books which record all financial transactions related to activities carried out by DHSA. The central office also maintains subsidiary records which provide details about specific projects.

A full and independent audit is obtained annually to verify the accuracy of financial records. Financial records are open to review by donor agencies upon request and DHSA wishes to cooperate with donors to ensure the proper management of funds entrusted to our care in behalf of the Afghan people 


\section{Gender}

DHSA strives to balance the distribution of benefits to all sectors of the communities in which we work. Many of our projects such as irrigation system rehabilitation, agricultural improvements and road repairs benefit the community as a whole including the most vulnerable groups, namely young children and female heads of households. Some of our projects, especially the well and hand pump installation and the vocational training and Health Education are more directly focused on the needs of these most vulnerable groups. DHSA neither approves nor promotes the current tendency to restrict the freedom of women in Afghanistan. DHSA constantly works to find new and creative ways to extend benefits to all members of the community regardless of gender. Also DHSA is trying to arrange training and working opportunity for ladies in home-base manner in the restricted area.

\section{Identification}

Comprehensive surveys have been done in Balkh Province, particularly in Balkh and Dawlatabad District. The UNIDATA survey, confirmed by contacts with UNOs and other NGOs, have revealed a significant need for infrastructure improvements in these three districts. Based on the surveys and DHSA's experience in the area, it is clear that the local residents place a high priority to provision of safe and potable water supplies and safe method of human wastes management. There is a high need and priority for orchards re-establishment and development and improvement of road access to the local markets and common facilities.

This proposal addresses all these needs within the capacity and capabilities which DHSA already possesses. Some districts under consideration are new for working there to DHSA activity but we have substantial contacts, in these districts, as we have running a field office in Mazar-Sharif since December 1996.

\section{ACTIVITIES}

\section{WATER SUPPLY AND SANITATION}

\subsection{Wells and Hand Pumps}

To reduce the incidence of water borne disease by cleaning existing wells or digging new wells in 100 sites throughout the 2 districts. All such wells are to be fitted with hand pumps and containment structures to prevent contamination and make obtaining the water easier.

100 wells will be cleaned or dug in the Balkh and Dawlatabad districts. These wells will be lined with concrete rings, have containment structures installed and will receive modern hand pumps in each case. Each well is expected to serve approximately 15-30 families. The community beneficiaries will contribute some sand and gravel as well as labor for digging or cleaning the wells. The local community will be responsible for the maintenance of the wells after installation. 
The table below shows the location of the wells and hand pumps.

\begin{tabular}{|l|l|l|c|}
\hline \multicolumn{1}{|c|}{ Province } & \multicolumn{1}{c|}{ District } & \multicolumn{1}{c|}{ Name of Villages } & \# of Wells \\
\hline Balkh & Balkh & Katori & 5 \\
\hline Balkh & Balkh & Niazi & 5 \\
\hline Balkh & Balkh & Hussain Abad & 5 \\
\hline Balkh & Balkh & Arab Ha & 5 \\
\hline Balkh & Balkh & Uzbakia & 6 \\
\hline Balkh & Balkh & Tarakhil & 6 \\
\hline Balkh & Balkh & Center & 5 \\
\hline Balkh & Balkh & Kole Anboh & 4 \\
\hline Balkh & Balkh & Bahauddin & 4 \\
\hline Balkh & Dawlatabad & Arab Ha & 5 \\
\hline Balkh & Dawlatabad & Surkh Gunbade Nawaqil & 4 \\
\hline Balkh & Dawlatabad & Dahrabad & 6 \\
\hline Balkh & Dawlatabad & Sare Asiabad & 6 \\
\hline Balkh & Dawlatabad & Khairabad & 6 \\
\hline Balkh & Dawlatabad & Mughulan & 7 \\
\hline Balkh & Dawlatabad & Ghujla & 5 \\
\hline Balkh & Dawlatabad & Saltoqe Hashimabad & 5 \\
\hline Balkh & Dawlatabad & Qarshigak & 8 \\
\hline Balkh & Dawlatabad & Taligak & 3 \\
\hline
\end{tabular}

The number of wells allocated for each village might be revised after reassessment

Training: Community beneficiaries will choose people to be responsible for the maintenance of the wells and will arrange to pay these individuals. DHSA will provide technical training in the field and make replacement parts available as necessary through the most cost effective means available. Spare parts will be sold to the technicians who will recover their costs from the community.

The community beneficiaries will receive a health education program in conjunction with the installation of the wells and pumps emphasizing the necessity of using clean water for human consumption and instruction in keeping the wells free of contamination.

Supply: Hand pumps currently manufactured in Mazar-i-Sharif and will be purchased there if they are suitable. In case of non availability of good local-made pumps, we purchase and import them. Cement is also available in Mazar. Spare parts should be available from the pump manufacturer. DHSA emphasizes to purchase and install the most common used Hand Pumps by other organizations to make the maintenance easier and spare parts can be available in the area. Production centers will be established to produce the concrete elements for lining and containing the wells. DHSA will arrange transport of concrete elements and pumps to the individual well sites.

Staff: DHSA will provide a supervising engineer and foremen at each district and will 
arrange for the necessary skilled and unskilled labor. Administration of the Balkh Province projects will be managed by Mazar Field Office as well as the technical and health education training staff.

\subsection{Surface Latrine Construction}

As a result of surveys performed in the target area, it was understood that the human waste management is very poor. People use unsaved and open surface latrines. In many cases people do not have latrine so they use lands and yards for defecation. Unfortunately, their drinking water sources are streams and revivers as well. This contributes to the contamination of drinking water and causes high morbidity and mortality rate among people specially the vulnerable group of the area residents.

DHSA has planned to introduce a scientific surface latrine to disinfect the feces and avoid the contamination of local environment by human waste. In the other hand the human waste can be changed to light disinfected compost to be used for agricultural purpose.

Supply: Cement and other necessary construction materials are available in Mazar-iSharif and will be purchased there and transported to the sites of construction by DHSA. It is not expected to be necessary to import supplies from outside to Mazar.

Staff: DHSA will provide a supervising engineer and foremen at each district and will arrange for the necessary skilled and unskilled labor. Administration of the Balkh Province projects will be managed by Mazar Field Office.

\section{RURAL INFRASTRUCTURE}

\subsection{Community Buildings}

To build 2 primary school in Khulm District. They are designed to serve approximately 1000 students, both boys and girls.

Needs assessments performed in Balkh province during the summer of 1997 indicated that the community desires the building of primary school buildings: Although a secondary school building has been constructed in the centers, primary schools are needed in outlying villages. The community leadership indicated that they have teachers and students available but need a building in which to operate a school. The community leadership indicated willingness to pay teachers and supply the school if a building can be built.

Supply: Locally available material will be used to the greatest extent possible. Stone sand, gravel and wooden elements are expected to be available locally. Cement, iron, lime, glass, paint and other manufactured elements will be purchased in Mazar. Community participation would be in the form of the locally available material, some unskilled labor and provision of security for the project site. DHSA will provide transport of materials to the building sites 
Staff: DHSA will supply a supervising engineer and foremen at the building sites, The community will supply part of the unskilled labor. DHSA will arrange for the skilled labor. Administration of the Balkh Province projects will be managed by Mazar Field Office.

\subsection{Roads and Culverts}

To construct 6 Small Bridges and 11 culverts as a part of the road repair activity and to provide protection for irrigation systems in the target area benefiting 7,500 families.

According to our needs assessment and meetings with community leaders in Balkh Province access to markets and services is a dominant problem. The area is completely very fine soil and there is no sand and gravel on the secondary roads. During rainy season roads cannot be used by vehicles. It becomes soft mud with depth of $50-60 \mathrm{~cm}$. Culverts and small bridges are in bad repair and are usually made from wood and soil. The poor condition of the secondary roads creates serious difficulties in the transportation system. The difficulty of travel makes transport of goods difficult and increases the cost both in and out of the area.

Supply: Cement and other necessary construction materials are available in Mazar-iSharif and will be purchased there and transported to the sites of construction by DHSA. It is not expected to be necessary to import supplies from outside to Balkh province.

Staff: DHSA will provide a supervising engineer at each district and will arrange for the necessary skilled labor. Administration of the Balkh Province projects will be managed by Mazar Field Office.

\section{AGRICULTURE}

\subsection{Nursery Establishment}

To establish 1 ha of nurseries land in Khulm District in order to provide an ongoing supply of appropriate grafted sapling stock to re-establish orchards in the target districts as well as determine the adaptation of newly improved variety of saplings By the end of the project it is expected that around 85,000 saplings of various species will be grown providing benefits to approximately 1.050 farming families.

Balkh Province have long been famous for its orchard products. As a result of the continuing conflict many of these orchards have been damaged or destroyed. Farmers who have the knowledge and skill to grow orchard crops often do not have the necessary finances to buy new stock and the skill to grow the trees from seed. Providing grafted saplings at a subsidized price will enable the local families to reestablish orchards and to provide themselves with a source of independently earned income. It will also improve the food security of the region and give local people a healthful and important addition to their normal diet.

Nurseries exist in Balkh Province but do not have the capacity to provide the number 
of saplings necessary to supply this objective over the long term. In addition, it is desirable to introduce new and improved types of trees and new varieties of common trees. Therefore, using DHSA skill and experience, new nurseries will be established to meet these needs.

Land appropriate for the establishment of the nurseries will be chosen by DHSA staff experienced in the establishment and management of nurseries. The land will be rented for a period of three years. Seeds of appropriate species will be purchased and brought to the nursery sites. Using established practices, DHSA staff will plant and tend the seeds and care for the resulting seedlings. At the appropriate time grafting will take place. After a period of 2 to 3 years grafted saplings suitable for transplanting to orchard sites will be available. It is expected that the 1 ha nurseries established will have produced approximately 85,000 grafted saplings which will be used in DHSA's ongoing program of sapling distribution. Revenues from the subsidized sale of saplings will provide the necessary funds to buy more seed and plant more trees so that the program should eventually become self sufficient.

Supply: Seeds for the establishment of the nursery will be purchased in the target Provinces if possible, or in Kabul, Ghazni and or Pakistan if necessary. DHSA will be responsible for the transport from the point of purchase to the nursery sites. Fertilizers and pesticides will be purchased at the most advantageous point possible and transported to the sites.

Training: 20 farmers will be trained as a part of the nursery establishment program. They will receive training on establishing, choosing of the land, seed selection, planting, fertilizer application, grafting and cutting of the saplings. The farmers will be trained directly and practically in the nurseries by the nursery staff.

Staff: There will be a supervisor responsible for the nursery site. He will be responsible to hire gardenersand unskilled laborers for specific tasks as necessary. Administration of the Balkh Province projects will be managed by Mazar Field Office.

\section{SOCIAL WELFARE}

\subsection{Ashiana}

DHSA proposes to operate a pilot project to gather data on the plight of the street children of Mazar-e-Sharif City while providing direct services to a limited number of 80 children as the information is gathered.

Present Situation: The long lasting war in Afghanistan has not only broken down the economic situation but has also disrupted the social system of Afghans. It has created refugees and disrupted the traditional close family ties. Most Afghan public services have been interrupted, especially primary and secondary education and health infrastructures. This situation has left hundreds of children in the streets of the major cities without any legal or community protection and on their own with various methods to obtain income. Most of them spend all the day in the streets. They shine shoes, wash and guard cars, carry luggage, collect recyclables and find a myriad of other ingenious ways to make money. The risks these children face lead to a high 
incidence of disease and death. Some statistics indicate over $10 \%$ mortality rate among children between the ages of 5 and 15. Many suffer from malnutrition and other kinds of illness including tuberculosis. For most of them, the streets become home. Inevitably these children become more prone to engage in marginal and illegal work. Many are led into the illicit and dangerous world of organized crime syndicates that run rings for pickpocketing, burglary, drug trafficking and prostitution. Aggression and abuse, exposing them to extreme hazards, mark the subculture that envelops the lives of these children.

Target Beneficiaries: This project will provide direct benefit to the 80 street children who will receive direct services during the course of the project. The data gathered and the projects developed as a result will eventually benefit the estimated $\mathbf{2 0 0}$ street children who reside in Mazar City. 80 Street Children will receive a range of medical, health and social services during the course of this project to gather information necessary for planning larger interventions in the future.

Implementation Strategy During the course of this pilot project social workers, medical personnel and vocational trainers will provide a range of services to 80 children who have made the streets their home. The medical and health services will include Basic Health Education. Personal Hygiene, baseline Medical Examination and Treatment and regular Medical and Psychological follow up. Light, nutritional meals will also be provided. Educational and vocational services will include early learning activities and basic literacy, drug and mine awareness training and exposure to a variety of vocational skills by interaction with craftsmen in their workshops. Social services will include medical and psychological follow up and liaison between the center and the families, when they exist, of the children.

The social workers will maintain a detailed family on each of the children which will allow them to maintain close contact and coordination among medical and psychological personnel, family members and the children. In addition, the social workers will perform a broader survey which will allow them to define the scope of the needs of street children in Mazare Sharif City, to find out how many of these children there actually are and to determine the needs these children have in order to be reintegrated into their society.

Based on the results of the survey and the experience of operating this center for street children, DHSA will design and implement larger and more comprehensive programs to meet the real and documented needs of this vulnerable sector of the population. 
RURAL REHABILITATION AND URBAN SOCIAL PROGRAM IN NORTHERN AFGHANISTAN SUMMARY TABLE

SUMMARY OF PROGRAM ACTION PLAN

\begin{tabular}{|c|c|c|c|c|c|c|c|c|}
\hline \multicolumn{2}{|c|}{ Location } & \multirow{2}{*}{\begin{tabular}{|c|} 
Population \\
Local \\
$\&$ \\
Refugees \\
\end{tabular}} & \multicolumn{2}{|c|}{ Water Supply \& Sanitation } & \multicolumn{2}{|c|}{ Infrastructure } & \multirow{2}{*}{$\begin{array}{r}\text { Agriculture } \\
\text { Nursery } \\
170000 \\
\text { Saplings } \\
\end{array}$} & \multirow{2}{*}{\begin{tabular}{|c} 
Social Welfare \\
Ashiana \\
Street \\
Children \\
\end{tabular}} \\
\hline Province & District & & Wells & Latrines & $\begin{array}{l}\text { Community } \\
\text { Buildings }\end{array}$ & Road/culvert & & \\
\hline \multirow{4}{*}{ Balkh } & Mazar & $\begin{array}{cc}L=166000 & \text { IDP }= \\
100000 & \text { UNIDATA } \\
\end{array}$ & & & & & & $80-100$ children \\
\hline & Balkh & $\begin{array}{rr}\mathrm{L}=101270 & \mathrm{R}= \\
6907 & \\
\end{array}$ & 45 Wells & & & $\begin{array}{c}6 \text { small Bridges + } \\
\text { one Culvert }\end{array}$ & & \\
\hline & Dawlatabad & $\begin{array}{|cc|}\mathrm{L}=108100 & \mathrm{R}= \\
7896 & \\
\end{array}$ & 55 Wells & $\begin{array}{l}\text { A Pilot Project, } 200 \\
\text { Surface Latrines }\end{array}$ & & 10 Culverts & & \\
\hline & Khulm & $\begin{array}{rl}L=75360 & R= \\
2950 & \\
\end{array}$ & & & $\begin{array}{c}2 \text { Primary School } \\
\text { Buildings }\end{array}$ & & $1 \mathrm{ha}, 85000$ saplings & \\
\hline
\end{tabular}

CONSOLIDATED PROGRAM BUDGET PLAN (in US\$)

\begin{tabular}{|c|c|c|c|c|c|c|c|c|c|}
\hline \multicolumn{2}{|c|}{ Location } & \multirow[b]{2}{*}{$\%$} & \multirow{2}{*}{$\begin{array}{c}\begin{array}{c}\text { Total } \\
\text { Program } \\
\text { Cost }\end{array} \\
\text { Us\$ } \\
295935,24 \\
\end{array}$} & \multicolumn{2}{|c|}{$\begin{array}{c}\text { Water Supply \& Sanitation } \\
43,4 \\
128309,27 \\
\end{array}$} & \multicolumn{2}{|c|}{$\begin{array}{c}\text { Infrastructure } \\
42,3 \\
125168,13 \\
\end{array}$} & \multirow{2}{*}{$\begin{array}{c}\text { Agriculture } \\
6,2 \\
18313,41 \\
6,2 \\
\text { Nursery }\end{array}$} & \multirow{2}{*}{ 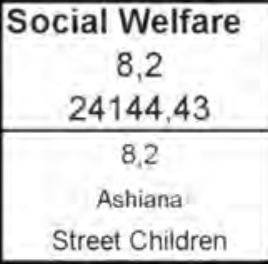 } \\
\hline Province & District & & & $\begin{array}{l}27,9 \\
\text { Wells }\end{array}$ & $\begin{array}{c}15,5 \\
\text { Latrines }\end{array}$ & $\begin{array}{l}19,1 \\
\text { Community } \\
\text { Buildings }\end{array}$ & $\begin{array}{c}23,2 \\
\text { Road/culv. }\end{array}$ & & \\
\hline \multirow{4}{*}{ Balkh } & Mazar & 8,2 & 24144,43 & & & & & & 24144,43 \\
\hline & Balkh & 27 & 80291,62 & 37127,61 & & & 43164,01 & & \\
\hline & Dawlatabad & 39 & 116753,07 & 45378,19 & 45803,47 & & 25571.41 & & \\
\hline & Khulm & 25 & 74746,12 & & & 56432.71 & & 18313,41 & \\
\hline \multicolumn{3}{|c|}{ Total } & 295935,24 & 82505,79 & 45803,47 & 56432,71 & 68735,42 & 18313,41 & 24144,43 \\
\hline
\end{tabular}




\section{RURAL REHABILITATION AND URBAN SOCIAL PROGRAM IN NORTHERN AFGHANISTAN \\ LOGICAL FRAMEWORK}

C. 1 WATER SUPPLY AND SANITATION: C.1.1 Wells and Hand Pumps

\begin{tabular}{|c|c|c|}
\hline INTERVENTION LOGIC & INDICATORS & $\begin{array}{l}\text { ASSUMPTIONS, RISKS } \\
\text { AND CONDITION }\end{array}$ \\
\hline $\begin{array}{l}\text { OVERALL OBJECTIVE: } \\
\text { To enhance the capacity of the target area to absorb } \\
\text { returnees and IDPS and to stabilize the local settled } \\
\text { population by: } 1 \text {, increasing food security: } 2 \text { improving } \\
\text { health standards; } 3 \text { increasing overall level of economic } \\
\text { and self sufficiency } 4 \text {, rehabilitating and developing rural } \\
\text { infrastructure through encouraging participation in } \\
\text { identifying problems, planning and implementing solutions } \\
\text { in the target community. }\end{array}$ & $\begin{array}{l}\text { No of refugees and IDPs return } \\
\text { Improve nutrition/health level of community } \\
\text { Availability of food in the market } \\
\text { Health oriented and other NGO records } \\
\text { UN records and surveys } \\
\text { Market Survey ( } 5 \text { years after program begins) } \\
\text { Active participation of community in the project cycle }\end{array}$ & \\
\hline $\begin{array}{l}\text { OBJECTIVE: } \\
\text { To reduce the incidence of water borne disease, } \\
\text { provide easy access to potable water and health } \\
\text { awareness benefiting direct approximately } 2,500 \\
\text { families by providing } 100 \text { wells cleaned and } \\
\text { equipped with hand pumps. }\end{array}$ & $\begin{array}{l}\text { Decreased water born diseases in the target area } \\
\text { Potable water is easily available } \\
\text { Community use covered wells instead stream/river water } \\
\text { Decreased diarrheal disease amongst the children under } 5 \\
\text { Health oriented NGOs report }\end{array}$ & $\begin{array}{l}\text { Avoid using water from other sources } \\
\text { (contaminated water) } \\
\text { Health education for the community } \\
\text { Avoid contamination of wells } \\
\text { Develop other components of } \\
\text { sanitation }\end{array}$ \\
\hline $\begin{array}{l}\text { OUTPUTS: } \\
100 \text { wells are cleaned } \\
\quad 100 \text { wells are lined by concrete ring } \\
\quad \quad 100 \text { Hand Pumps are installed } \\
\quad \quad 100 \text { wells are covered by top works } \\
-\quad 5-6 \text { persons are trained for maintenance of pumps } \\
\quad \quad \text { Primary Health education for beneficianes }\end{array}$ & $\begin{array}{l}\text { Potable water is available in the area } \\
100 \text { well equipped with hand pumps physically exist in the area } \\
\text { Agency list, documents and reports } \\
\text { Third party report }\end{array}$ & $\begin{array}{l}\text { Maintenance of hand pumps } \\
\quad \text { Avoid contamination } \\
\quad \text { Avoid damage } \\
\quad \text { Continue e pansion of program }\end{array}$ \\
\hline $\begin{array}{l}\text { WORKS (Activities): } \\
\text { Budget planning } \\
\text { Action planing } \\
\text { Purchase and transport of material to the site } \\
\text { Purchase and transport of hand pumps } \\
5 \text { Production centers establishment } \\
\text { community contact and health education } \\
\text { cleaning of wells and installation of pumps } \\
\text { Coordination with NGOs/Community } \\
\text { Supervision, monitoring, evaluation, report }\end{array}$ & $\begin{array}{l}\text { Enough cash flow available } \\
\quad \text { Works going on as planned } \\
\text { - Production center established } \\
\text { Hand pumps purchased and transported } \\
\text { Iron concrete material produced } \\
\text { - Staff and labor hired and are working } \\
\text { - Installation of pumps are going on }\end{array}$ & $\begin{array}{l}\text { People participate in the } \\
\text { implementation } \\
\text { - Community have time to participate } \\
\text { - } \quad \text { Security and climatic condition } \\
\text { - Community dig wills } \\
\text { - Authorities are cooperative }\end{array}$ \\
\hline $\begin{array}{l}\text { INPUTS: } \\
\quad \text { Expendable material } \\
\quad \text { Non expendable material } \\
\quad \text { Labor } \\
\quad \text { Staff }\end{array}$ & $\begin{array}{l}\text { MEANS: } \\
\text { Cement } 1500 \text { bags, stone } 280 \mathrm{~m}^{3} \text {, sand and gravel } 470 \mathrm{~m}^{3} \text { Gl wire } 1040 \mathrm{~kg} \text {, steel bar } 1680 \mathrm{~kg} \text {, } \\
\text { hand pump } 100 \text { complete set, clamps } 1000 \text { each, plastic rope } 150 \mathrm{~kg} \text {, jointing solution } 15 \mathrm{~kg} \text {, } \\
\text { raising main } 3000 \mathrm{~m} \text {, ring mould } 24 \text {, post mould } 8 \text {, top ring mold } 8 \text {, field camp equipment } 6 \text { sets, } \\
\text { small water pump } 3 \text {, small tools } 24 \text { sets, transportation } 168000 \text { Rs, skilled labor } 300 \text { Manday, } \\
\text { unskilled labor } 1400 \text { Manday, site engineer } 3 \times 4 \text { months, guard } 6 \times 4 \text { months and foreman } 3 \times 4 \\
\text { months: } \\
\text { COST: } \\
\text { Community participation part of labor, security, digging of part of wells local available material } \\
\text { Donor participation } 82505.79 \text { US\$ } \\
\text { Agency participation. office support, management }\end{array}$ & $\begin{array}{l}\text { Availability of material } \\
\text { - Availability of qualified staff } \\
\text { Natural condition } \\
\text { Community has enough time to } \\
\text { participate in the implementation } \\
\text { Reasonable Level of Security } \\
\text { - Access to the sites } \\
\text { Timely arrival of funds }\end{array}$ \\
\hline
\end{tabular}


RURAL REHABILITATION AND URBAN SOCIAL PROGRAM IN NORTHERN AFGHANISTAN

LOGICAL FRAMEWORK

C. 1 WATER SUPPLY AND SANITATION: C.1.2 SUrface Latrines

\begin{tabular}{|c|c|c|}
\hline INTERVENTION LOGIC & INDICATORS & $\begin{array}{l}\text { ASSUMPTIONS, RISKS } \\
\text { AND CONDITION }\end{array}$ \\
\hline $\begin{array}{l}\text { OVERALL OBJECTIVE: } \\
\text { To enhance the capacity of the target area to absorb } \\
\text { returnees and IDPs and to stabilize the local settled } \\
\text { population by } 1 \text {. increasing food security, } 2 \text { improving } \\
\text { health standards, } 3 \text { increasing overall level of economic } \\
\text { and self sufficiency } 4 \text {, rehabilitating and developing rural } \\
\text { infrastructure through encouraging participation in } \\
\text { identifying problems, planning and implementing solutions } \\
\text { in the target community. }\end{array}$ & $\begin{array}{l}\text { No. of refugees and IDPs return } \\
\text { Improve nutrition/health level of community } \\
\text { Availability of food in the market } \\
\text { Health oriented and other NGO records } \\
\text { UN records and surveys } \\
\text { Market Survey ( } 5 \text { years after program begins) } \\
\text { Active participation of community in the project cycle }\end{array}$ & \\
\hline $\begin{array}{l}\text { OBJECTIVE: } \\
\text { To reduce the incidence of transmitting diseases } \\
\text { and to manage the human wastes by constructing } \\
200 \text { surface latrines benefiting } 200 \text { families, directly } \\
\text { and the residents of the area indirectly, in a pilot } \\
\text { project. }\end{array}$ & $\begin{array}{l}\text { People use Covered Latrines. } \\
\text { incidence of transmitting diseases are reduced } \\
\text { Health status is better } \\
\text { Agency record } \\
\text { UNOs and NGOs reports }\end{array}$ & $\begin{array}{l}\text { Availability of PHC components in } \\
\text { the area. } \\
\text { People use all their knowledge and } \\
\text { opportunity to manage the human } \\
\text { wastes }\end{array}$ \\
\hline $\begin{array}{l}\text { OUTPUTS: } \\
200 \text { Surface Latrine are constructed by the available } \\
\text { fund of agency and community participation. } \\
\text { The } 200 \text { benefiting families receive Health } \\
\text { Awareness as well. }\end{array}$ & $\begin{array}{l}200 \text { constructed Latrines exist in the target area. } \\
\text { Target beneficiaries have enough knowledge about transmitting diseases } \\
\text { They know how to use the latrines } \\
\text { Agency list, photos documents and monitoring reports } \\
\text { Third party report }\end{array}$ & $\begin{array}{l}\text { Community interest in this objective } \\
\text { Satisfactory community participation } \\
\text { in PRA method } \\
\text { They use each part of the latrine } \\
\text { properly as they learned }\end{array}$ \\
\hline $\begin{array}{l}\text { WORKS (Activities): } \\
\text { Budget planning } \\
\text { Action planing } \\
\text { Community contact for participation } \\
\text { Purchase and transport of material to the site } \\
\text { Arranging manpower for implementation } \\
\text { Coordination with NGOS/Community } \\
\text { Supervision, monitonng, evaluahion, report }\end{array}$ & $\begin{array}{l}\text { Enough cash flow available } \\
\text { Works going on as planned } \\
\text { Material purchased and transported } \\
\text { Construction work is going on } \\
\text { Staff and labor hired and are working }\end{array}$ & $\begin{array}{l}\text { Natural condition } \\
\text { Community has enough time to } \\
\text { participate in the implementation } \\
\text { Reasonable Level of Security } \\
\text { Access to the sites }\end{array}$ \\
\hline $\begin{array}{l}\text { INPUTS: } \\
\text { Expendable material } \\
\text { Non expendable material } \\
\text { Labor } \\
\text { Staff } \\
\text { Transport } \\
\text { Managerial skill and tools }\end{array}$ & $\begin{array}{l}\text { MEANS: Stone } 600 \mathrm{~m}^{3} \text {, cement } 600 \text { bags, sand } \& \text { gravel } 66.8 \mathrm{~m}^{3} \text {, soil } 240 \mathrm{~m} 3 \text {, wooden bean } 1800 \\
\text { each, plank } 1000 \text { each, chute } 600 \mathrm{~m} \text {, CPV Pipe } 1200 \mathrm{~m} \text {, steel bar } 1304 \mathrm{~kg} \text {, bending wire } 100 \mathrm{~kg} \text {, } \\
\text { nail } 100 \mathrm{~kg} \text {, transport } 258400 \mathrm{Rs} \text {, tools } 19600 \mathrm{Rs} \text {, skilled labor } 1200 \text { manday, unskilled labor } \\
200 \text { manday, site engineer } 2 \times 4 \text { months, foreman } 4 \times 4 \text { months, guard } 2 \times 4 \text { months. } \\
\text { COST: } \\
\text { Community participation. Land for building, security, part of labor, part of local available material } \\
\text { Donor participation: } 45,803.47 \text { US } \$ \\
\text { Agency participation: Office support, management }\end{array}$ & $\begin{array}{l}\text { Availability of material } \\
\quad \text { Availability of qualified staff } \\
\quad \text { Timely arrival of funds }\end{array}$ \\
\hline
\end{tabular}


RURAL REHABILITATION AND URBAN SOCIAL PROGRAM IN NORTHERN AFGHANISTAN

LOGICAL FRAMEWORK

C. 2 INFRASTRUCTURE: C.2.1 Community Building

\begin{tabular}{|c|c|c|}
\hline INTERVENTION LOGIC & INDICATORS & $\begin{array}{l}\text { ASSUMPTIONS, RISKS } \\
\text { AND CONDITION }\end{array}$ \\
\hline $\begin{array}{l}\text { OVERALL OBJECTIVE } \\
\text { To enhance the capacity of the target area to absorb } \\
\text { returnees and IDPs and to stabilize the local settled } \\
\text { population by: } 1 \text { increasing food security; } 2 \text { improving } \\
\text { health standards, } 3 \text {. increasing overall level of economic } \\
\text { and self sufficiency } 4 \text {, rehabilitating and developing rural } \\
\text { infrastructure through encouraging participation in } \\
\text { identifying problems, planning and implementing solutions } \\
\text { in the target community. }\end{array}$ & $\begin{array}{l}\text { No. of refugees and IDPS return } \\
\text { Improve nutrition/health level of community } \\
\text { Availability of food in the market } \\
\text { Health oriented and other NGO records } \\
\text { UN records and surveys } \\
\text { Market Survey ( } 5 \text { years after program begins) } \\
\text { Active participation of community in the project cycle }\end{array}$ & \\
\hline $\begin{array}{l}\text { OBJECTIVE: } \\
\text { To provide educational opportunity for approximately } \\
1000 \text { students annually by construction } 2 \text { primary } \\
\text { schools building in Khulm District. }\end{array}$ & $\begin{array}{l}\text { Newly built school is used by the community regularly } \\
\text { Number of educated children are increased } \\
\text { Agency record } \\
\text { UNOS and NGOs reports }\end{array}$ & $\begin{array}{l}\text { Availability of teacher and teaching } \\
\text { material } \\
\text { - Curriculum for teaching } \\
\text { - Continuation and sustainability of } \\
\text { educational program. }\end{array}$ \\
\hline $\begin{array}{l}\text { OUTPUTS: } \\
\text { Two primary schools building in Khulm district of } \\
\text { Balkh province }\end{array}$ & $\begin{array}{l}\text { School building physically exist In the area } \\
\text { Students use the school building } \\
\text { Agency list, documents and reports } \\
\text { Third party report }\end{array}$ & $\begin{array}{l}\text { Maintenance of buildings } \\
\quad \text { Keeping them from damage } \\
\text { Use them properly }\end{array}$ \\
\hline $\begin{array}{l}\text { WORKS (Activities): } \\
\quad \text { Budget planning } \\
\quad \text { Action planing } \\
\text { community contact for participation } \\
=\quad \text { Purchase and transport of material to the site } \\
-\quad \text { Community contract for land of buildings } \\
-\quad \text { Coordination with NGOs/Community } \\
\text { - }\end{array}$ & $\begin{array}{l}\text { Enough cash flow available } \\
\text { Works going on as planned } \\
\text { Material purchased and transported } \\
\text { Construction work is going on } \\
\text { Staff and labor hired and are working }\end{array}$ & $\begin{array}{l}\text { Natural condition } \\
\text { Community has enough time to } \\
\text { participate in the implementation } \\
\text { Reasonable Level of Security } \\
\text { Access to the sites }\end{array}$ \\
\hline $\begin{array}{l}\text { INPUTS: } \\
\text { Expendable material } \\
\text { Non expendable material } \\
-\quad \text { Labor } \\
\text { - Staff } \\
\text { transport }\end{array}$ & $\begin{array}{l}\text { MEANS: } \\
\text { Please program budget for detail } \\
\text { COST: } \\
\text { Community participation: Land for building, security, part of labor, part of local available material } \\
\text { Donor participation: } 56,432.71 \text { US\$ } \\
\text { Agency participation. Office support, management }\end{array}$ & $\begin{array}{l}\text { Availability of material } \\
\text { Availability of qualified staff } \\
\text { Timely arrival of funds }\end{array}$ \\
\hline
\end{tabular}




\section{RURAL REHABILITATION AND URBAN SOCIAL PROGRAM IN NORTHERN AFGHANISTAN \\ LOGICAL FRAMEWORK \\ C.2 INFRASTRUCTURE: C.2.2 Road/Culverts}

\begin{tabular}{|c|c|c|}
\hline INTERVENTION LOGIC & INDICATORS & $\begin{array}{l}\text { ASSUMPTIONS, RISKS } \\
\text { AND CONDITION }\end{array}$ \\
\hline $\begin{array}{l}\text { OVERALL OBJECTIVE: } \\
\text { To enhance the capacity of the target area to absorb } \\
\text { returnees and IDPs and to stabilize the local settled } \\
\text { population by: } 1 \text {, increasing food security: } 2 \text {, Improving } \\
\text { health standards; } 3 \text {. increasing overall level of economic } \\
\text { and self sufficiency } 4 \text {. rehabilitating and developing rural } \\
\text { infrastructure through encouraging participation in } \\
\text { identifying problems, planning and implementing solutions } \\
\text { in the target community }\end{array}$ & $\begin{array}{l}\text { No. of refugees and IDPs return } \\
\text { Improve nutrition/health level of community } \\
\text { Availability of food in the market } \\
\text { Health oriented and other NGO records } \\
\text { UN records and surveys } \\
\text { Market Survey ( } 5 \text { years after program begins) } \\
\text { Active participation of community in the project cycle }\end{array}$ & \\
\hline $\begin{array}{l}\text { OBJECTIVE: } \\
\text { To improve access of the target community to the } \\
\text { market and other facilities by roads improvement. }\end{array}$ & $\begin{array}{l}\text { Reduce the cost of transportation } \\
\text { People can reach to the local market easily } \\
\text { Fresh food commodities are now available in the market } \\
\text { Cost of material is reduced } \\
\text { Clint flow of facilities are increased } \\
\text { Agency record } \\
\text { UNOs and NGOs reports }\end{array}$ & $\begin{array}{l}\text { Availability of transport } \\
\text { Enough products for transport }\end{array}$ \\
\hline $\begin{array}{l}\text { OUTPUTS: } \\
\text { To construct } 6 \text { small bridge; } 11 \text { culverts benefiting } \\
7.500 \text { families }\end{array}$ & $\begin{array}{l}6 \text { small bridge and } 11 \text { culverts benefiting exist in the area } \\
\text { Easy transportation and travelling } \\
\text { Agency list, documents and monitoring reports } \\
\text { Third party report }\end{array}$ & $\begin{array}{l}\text { Maintenance of bridges and culverts } \\
\text { Keeping them from damage } \\
\text { Use them properly } \\
\text { Satisfactory community participation } \\
\text { in PRA method }\end{array}$ \\
\hline $\begin{array}{l}\text { WORKS (Activities): } \\
\text { Budget planning } \\
\text { Action planing } \\
\text { community contact for participation } \\
\text { Purchase and transport of material to the site } \\
\text { Arranging manpower for implementation } \\
\text { - Coordination with NGOS/Community } \\
\text { Supervision, monitoring, evaluation, report }\end{array}$ & $\begin{array}{l}\text { Enough cash flow available } \\
\text { Works going on as planned } \\
\text { Material purchased and transported } \\
\text { Construction work is going on } \\
\text { Staff and labor hired and are working }\end{array}$ & $\begin{array}{l}\text { Natural condition } \\
\text { Community has enough time to } \\
\text { participate in the implementation } \\
\text { Reasonable Level of Security } \\
\text { Access to sites }\end{array}$ \\
\hline $\begin{array}{l}\text { INPUTS: } \\
\quad \text { Expendable material } \\
\text { Non expendable material } \\
\text { Labor } \\
\quad \text { Staff } \\
\quad \text { Transport } \\
\text { Managerial skill and tools }\end{array}$ & $\begin{array}{l}\text { MEANS: Stone } 811,5 \mathrm{~m}^{3} \text {, cement } 1903 \text { bags sand \& gravel } 411,49 \mathrm{~m}^{3} \text {, sand } 47.7 \mathrm{~m}^{3} \text {, wooden } \\
\text { bean } 1023 \text { each, plank } 1035 \text { each, steel bar } 7762 \mathrm{~kg} \text {, bending wire } 52.5 \mathrm{~kg} \text {, nail } 63 \mathrm{~kg} \text {, transport } \\
182916 \mathrm{Rs} \text {, tools } 750926 \mathrm{Rs} \text {, skilled labor } 1032 \mathrm{manday} \text {, unskilled labor } 1870 \text { manday, site engineer } \\
2 \times 3 \text { months, foreman } 4 \times 3 \text { months, guard } 4 \times 3 \text { months } \\
\text { COST: } \\
\text { Community participation, Land for building, security, part of labor, part of local available material } \\
\text { Donor participation } 687,535.42 \text { USs } \\
\text { Agency participation: Office support, management }\end{array}$ & $\begin{array}{l}\text { Availability of material } \\
\quad \text { Availability of qualified staff } \\
\quad \text { Timely arrival of funds }\end{array}$ \\
\hline
\end{tabular}




\section{RURAL REHABILITATION AND URBAN SOCIAL PROGRAM IN NORTHERN AFGHANISTAN \\ LOGICAL FRAMEWORK \\ C.3 AGRICULTURE: C.3.1 Nursery}

\begin{tabular}{|c|c|c|}
\hline INTERVENTION LOGIC & INDICATORS & $\begin{array}{l}\text { ASSUMPTIONS, RISKS } \\
\text { AND CONDITION }\end{array}$ \\
\hline $\begin{array}{l}\text { OVERALL OBJECTIVE: } \\
\text { To enhance the capacity of the target area to absorb } \\
\text { returnees and IDPs and to stabilize the local settled } \\
\text { population by: } 1 \text { increasing food security, } 2 \text { improving } \\
\text { health standards, } 3 \text { increasing overall level of economic } \\
\text { and self sufficiency } 4 \text { rehabilitating and developing rural } \\
\text { infrastructure through encouraging participation in } \\
\text { identifying problems, planning and implementing solutions } \\
\text { in the target community. }\end{array}$ & $\begin{array}{l}\text { No. of refugees and IDPs return } \\
\text { Improve nutrition/health level of community } \\
\text { Availability of food in the market } \\
\text { Health oriented and other NGO records } \\
\text { UN records and surveys } \\
\text { - Market Survey ( } 5 \text { years after program begins) } \\
\quad \text { Active participation of community in the project cycle }\end{array}$ & \\
\hline $\begin{array}{l}\text { OBJECTIVE: } \\
\text { Orchards Reestablished through nurseries } \\
\text { establishing then sapling distribution } \\
\text { Farm families have another source of income } \\
\text { Diets, food security are improved in target area }\end{array}$ & $\begin{array}{ll} & \text { Nurseries established } \\
& \text { Orchards established } \\
& \text { Sapling are growing well } \\
& \text { More Fruit in Market } \\
\text { Decreased Incidence of Vitamin Deficiency Disease } \\
\text { Increased income of farmers } \\
\text { 3rd Party Monitor Review }\end{array}$ & $\begin{array}{l}\text { Farmers maintain orchards properly } \\
\text { Hostilities do not destroy orchards } \\
\text { Varieties of trees adapted to area } \\
\text { No catastrophic disease or pest } \\
\text { outbreaks. Access to market. } \\
\text { Proper storing and distribution of } \\
\text { crops. }\end{array}$ \\
\hline $\begin{array}{l}\text { OUTPUTS: } \\
1 \text { ha of nurseries consist of about } 85,000 \text { grafted } \\
\text { and improved sapling benefiting } 1050 \text { farm families } \\
\text { to receive sapling and plant orchards, at the end. } \\
20 \text { farmers trained in nurseries establishing }\end{array}$ & $\begin{array}{l}5 \text { jeribs ( } 1 \text { ha) nurseries established } \\
\text { Grafting completed } \\
\text { Trained farmers for establishing and grafting of nursery available in the community } \\
\text { Concerned number of sapling available for distribution } \\
\text { Physical existing of } 1 \text { ha nurseries in the target area. } \\
\text { DHSA Field Agronomist Records } \\
\text { Community Forum (Shuras) Records } \\
\text { Other NGOS/UNOS reports }\end{array}$ & $\begin{array}{l}1050 \text { farm families identified and } \\
\text { purchased saplings at subsidized } \\
\text { price } \\
\text { Planting, fertilizing done properly } \\
\text { Less than } 5 \% \text { loss after planting }\end{array}$ \\
\hline $\begin{array}{l}\text { WORKS (Activities): } \\
\text { Budget planning } \\
\text { Action planing } \\
\text { Selection of land } \\
\text { Field training } \\
\text { Routine works } \\
\text { Coordination with NGOs/Community } \\
\text { Supervision, monitoring, evaluation, report }\end{array}$ & $\begin{array}{l}\text { Enough cash flow available } \\
\text { Works going on as planned } \\
\text { Nurseries are established } \\
\text { Community participate in establishing and introduce farmers for training } \\
\text { Records of meeting and exchange of informatıon/skills with community and others. }\end{array}$ & $\begin{array}{l}\text { Selection of healthy seed, selection of } \\
\text { good land, enough water, timely grafting. } \\
\text { selection of improved variety of graft, } \\
\text { adaptation of seedling. suitable climatic } \\
\text { condition, pest and diseases control. } \\
\text { Cutting and opening of grafted sapling } \\
\text { properly, keeping of nurseries from } \\
\text { damage. }\end{array}$ \\
\hline $\begin{array}{l}\text { INPUTS: } \\
\text { Land lease } \\
\text { Seeds } \\
\text { Planting cost } \\
\text { Tools and equipment } \\
\text { Drugs/fertilizers } \\
\text { Training cost } \\
\text { Staff/labor } \\
\end{array}$ & $\begin{array}{l}\text { MEANS: } \\
\text { Land lease } 1 \text { ha for three years, } 100 \mathrm{~kg} \text { seeds, oultivation cost, dung } 10 \text { tracks. Fertilizer } 10 \text { bags, } \\
\text { sulfur } 2 \text { bags, pesticides } 10 \mathrm{It} \text {, grafting cost for } 100,000 \text { trees, weeding cost, gardener } 3 \text {, field } \\
\text { supervisor } 1 \text {, protection screen wall } 5 \text { jernbs, tools, transport cost } \\
\text { COST: } \\
\text { Community participation: Security, local transportation, part of labour, planting and follow up } \\
\text { Donor participation: } 18,313,41 \text { us } \$ \\
\text { Agency participation office support, management }\end{array}$ & $\begin{array}{l}\text { Availability of material } \\
\text { Availability of qualified staff } \\
\text { Natural condition } \\
\text { Community has enough time to } \\
\text { participate in the implementation } \\
\text { Reasonable Level of Security } \\
\text { Access to sites } \\
\text {-Timely arrival of funds }\end{array}$ \\
\hline
\end{tabular}




\section{RURAL REHABILITATION AND URBAN SOCIAL PROGRAM IN NORTHERN AFGHANISTAN \\ LOGICAL FRAMEWORK \\ C.4 SOCIAL WELFARE: C.4.1 Ashiana (Street Children)}

\begin{tabular}{|c|c|c|}
\hline INTERVENTION LOGIC & INDICATORS & $\begin{array}{l}\text { ASSUMPTIONS, RISKS } \\
\text { AND CONDITION }\end{array}$ \\
\hline $\begin{array}{l}\text { OVERALL OBJECTIVE } \\
\text { To enhance the capacity of the target area to absorb } \\
\text { returnees and IDPS and to stabilize the local settled } \\
\text { population by } 1 \text { increasing food security, } 2 \text {. improving } \\
\text { health standards; } 3 \text { increasing overall level of economic } \\
\text { and self sufficiency } 4 \text { rehabilitating and developing rural } \\
\text { infrastructure through encouraging participation in } \\
\text { identifying problems, planning and implementing solutions } \\
\text { in the target community. }\end{array}$ & $\begin{array}{l}\text { No. of refugees and IDPs return } \\
\text { Improve nutrition/health level of community } \\
\text { Availability of food in the market } \\
\text { Health oriented and other NGO records } \\
\text { UN records and surveys } \\
\text { Market Survey (5 years after program begins) } \\
\text { Active participation of community in the project cycle }\end{array}$ & \\
\hline $\begin{array}{l}\text { OBJECTIVE: } \\
\text { To gather primary data about the street children on } \\
\text { which to comprehensive program while providing } \\
\text { services to a limited number of } 80-100 \text { street } \\
\text { children. }\end{array}$ & $\begin{array}{l}\text { Number of street children is going to decrease } \\
\text { Child abuse reduced and the target children oriented to the regular education. } \\
\text { Behavior of these children have been changed } \\
\text { Data by other agencies }\end{array}$ & $\begin{array}{l}\text { Authorities, society and institutions } \\
\text { support the program } \\
\text { They try to consider the children } \\
\text { right } \\
\text { Act against child abuse. }\end{array}$ \\
\hline $\begin{array}{l}\text { OUTPUTS } \\
80-100 \text { street children will be gathered and served } \\
\text { in Ashiana and a comprehensive survey of the city } \\
\text { well be performed. }\end{array}$ & $\begin{array}{l}\text { An Ashiana center exist in Mazar city where } 80-100 \text { children reported daily or so regularly, } \\
\text { Agency report and documents } \\
\text { External evaluators data }\end{array}$ & $\begin{array}{l}\text { Working opportunity } \\
\quad \text { Follow up of children } \\
\quad \text { Political and economical stability }\end{array}$ \\
\hline $\begin{array}{l}\text { WORK } \\
\quad \text { Work plan } \\
\text { Selection of stuff } \\
\text { Arrangement of Ashiana centers } \\
\text { Survey and data gathering } \\
\text { Coordination with GOs/NGOs } \\
\quad \text { Follow up of street children and home visit. } \\
\quad \text { Supervision, monitoring, evaluation, report }\end{array}$ & $\begin{array}{l}\text { Authorities, community and society are agree with the program and cooperate. Home Visits } \\
\text { are being performed and find out the reason, cause and solution of this problem. } \\
\text { Number of meetings held with community, GOS/NGOs. } \\
\text { Data gathering, analysis and making decision accordingly }\end{array}$ & $\begin{array}{l}\text { Proper social working in the society } \\
\text { Children families support and agree } \\
\text { to the program and allow their } \\
\text { children to use the center } \\
\text { Additional income for children } \\
\text { families should be prepared } \\
\text { Being careful about child abusers }\end{array}$ \\
\hline $\begin{array}{l}\text { INPUTS: } \\
\text { Ashiana place } \\
\text { Personnel } \\
\text { Teaching and training material } \\
\text { Expenses }\end{array}$ & $\begin{array}{l}\text { MEANS: } \\
\text { Personnel, non expendables and expenses. Please see budget for detail information } \\
\text { COST: } \\
\text { Community/Society participation Security, participation in the data gathering } \\
\text { Donor participation: } 24,144.43 \text { US\$ } \\
\text { Agency participation. Office support, management }\end{array}$ & $\begin{array}{l}\text { Availability of material } \\
\text { Availability of qualified staff } \\
\text { Natural condition } \\
\text { Reasonable Level of Security } \\
\text { Timely arrival of funds }\end{array}$ \\
\hline
\end{tabular}


RURAL REHABILITATION AND URBAN SOCIAL PROGRAM

IN NORTHERN AFGHANISTAN

BUDGET SUMMARY

\begin{tabular}{|c|c|c|}
\hline BUDGET ITEMS & AMOUNT IN USS & PERCENTAGE \\
\hline A. ADMINISTRATION & 42266,05463 & 10,0 \\
\hline A. 1 STAFF SALARIES & 19960,91 & 4.7 \\
\hline A.2 OFFICE EXPENSES & 9802,30 & 2,3 \\
\hline A 3 LOGISTIC & 11821,12 & 2,8 \\
\hline A.4 AUDIT FEE & 681,73 & 0,2 \\
\hline B. OPERATION COST & 84798,72 & 20,0 \\
\hline B. 1 STAFF SALARIES & 33336,36 & 7,9 \\
\hline B 2 OFFICE EXPENSES & 18213,02 & 4,3 \\
\hline B 3 LOGISTIC & 29636,19 & 7,0 \\
\hline B 4 CAPACITY BUILDING/TRAINING & 2045,18 & 0,5 \\
\hline B. 5 EXTERNAL EVALUATION & 1567,97 & 0,4 \\
\hline C- PROGRAM COST & 295935,24 & 70,0 \\
\hline C. 1 WATER SUPPLY AND SANITATION & 128309,27 & 30,3 \\
\hline C. 2 INFRASTRUCTURES & 125168,13 & 29,6 \\
\hline G.3 AGRICULTURE & 18313,41 & 4,3 \\
\hline C 4 SOCIAL PROGRAM & 24144,43 & 5.7 \\
\hline TOTAL PROJECT COST & 423000,0 & 100,0 \\
\hline
\end{tabular}




\section{ADMINISTRATION COST}

A-1. STAFF SALARY

\begin{tabular}{|c|c|c|c|c|c|c|}
\hline No. & TEM & Number & Hom & aningst & R. & 1) \\
\hline 1 & Coordinator & 1 & 18 & 15000 & 270000 & 6135.53 \\
\hline 2 & Finance manager & 1 & 18 & 10000 & 180000 & 4090,35 \\
\hline 3 & Administrator & 1 & 18 & 8000 & 144000 & 3272,28 \\
\hline 4 & Accountant Asst /Cashier & 1 & 18 & 5000 & 90000 & 2045,18 \\
\hline 5 & Driver & 1 & 18 & 4000 & 72000 & 1636,14 \\
\hline 6 & Guards & 2 & 18 & 2400 & 86400 & 1963,37 \\
\hline \multirow[t]{2}{*}{7} & Servant & 1 & 18 & 2000 & 36000 & 818,07 \\
\hline & Sub-total Staff Salary & & & & 878400 & 19960,91 \\
\hline
\end{tabular}

A-2. OFFICE EXPENSES

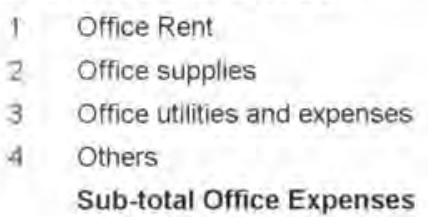

$\begin{array}{rrr}10000 & 180000 & 4090,35 \\ 9000 & 162000 & 3681,32 \\ 4500 & 81000 & 1840,66 \\ & 8360 & 189,97 \\ & 431360 & 9802,30\end{array}$

A-3. LOGISTIC

1 Vehicle rent

2 Fuel and Lubricants

3 Vehicle Maintenance Sub-total Office Logistic
10000

15000

5600
3863,11

5794,66

2163,34

95200

520200

11821,12

A-4. AUDIT FEE

Audit Fee

30000

681,73

TOTAL ADMINISTRATION COST 


\section{OPERATION COST}

B-1. STAFF SALARY

\begin{tabular}{|c|c|c|c|c|c|c|}
\hline No. & It EMS & Chiner & month & 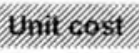 & 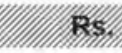 & IIIIs) \\
\hline 1 & Program Coordinator & 1 & 18 & 20000 & 360000 & 8180,70 \\
\hline 2 & Engineers & 2 & 18 & 8000 & 288000 & 6544,5 \\
\hline 3 & Agriculturists & 1 & 18 & 8000 & 144000 & 3272,28 \\
\hline 4 & Administrators & 1 & 18 & 8000 & 144000 & 3272,2 \\
\hline 5 & Accountants & 1 & 18 & 8000 & 144000 & 3272,28 \\
\hline 6 & Cashiers & 1 & 18 & 4000 & 72000 & 1636,1 \\
\hline 7 & Drivers & 2 & 18 & 4000 & 144000 & 3272,28 \\
\hline 8 & Guard & 3 & 18 & 2500 & 135000 & 3067.76 \\
\hline \multirow[t]{2}{*}{9} & Servants & 1 & 18 & 2000 & 36000 & 818.07 \\
\hline & Sub-total Staff Salary & & & & 1467000 & 33336,3 \\
\hline
\end{tabular}

B-2. OFFICE EXPENSES

$\begin{array}{ll}1 & \text { Office rent } \\ 2 & \text { Office utilities } \\ 3 & \text { Office stationery and expenses } \\ 4 & \text { Communication } \\ 5 & \text { Computers } \\ 6 & \text { Printers } \\ 7 & \text { Furniture } \\ 8 & \text { Others }\end{array}$

Sub-total Office Expenses

\section{B-3. LOGISTIC}

2 Vehicle fuel and Maintenance

3 local staff travel

4 Others

Sub-total Office Logistic
1 Vehicle rent

$\begin{array}{rrrr}18 & 9000 & 162000 & 3681,32 \\ 18 & 10000 & 180000 & 4090,35 \\ 18 & 10000 & 180000 & 4090,35 \\ 18 & 10000 & 180000 & 4090,35 \\ & 40000 & 40000 & 908,97 \\ & 24000 & 24000 & 545,38 \\ & 20000 & 20000 & 454,48 \\ & & 15482 & 351,82 \\ & & 801482 & 18213,02\end{array}$

$\begin{array}{lr}18 & 15000 \\ 18 & 18000 \\ 18 & 5000\end{array}$

540000

12271.05 14725,26 2045,18 594,69 29636,19

1304170

90000

2045,18

1 Staff Capacity Building/Workshops

B-5. EVALUATION MONITORING

1 External Evaluation Fee

69000

1567,97

3641652

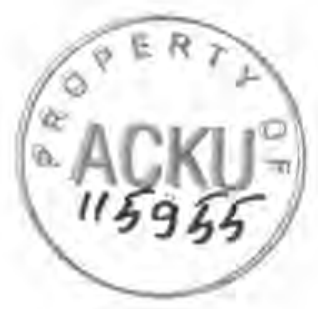




\section{PROGRAM COST}

1. WATER SUPPLY AND SANITATION

1. 1 WELL CLEANING AND HAND PUMPS INSTALLATION $100 \mathrm{wells}$

\begin{tabular}{|c|c|c|c|c|c|c|c|}
\hline Nom: & HEMS & thin & nimisetr & Month & Iningst & RStm & uss \\
\hline & \multicolumn{7}{|l|}{ 1-Expendable Material } \\
\hline 1 & Cement & bag & 1500 & & 325 & 487500 & 11078,03 \\
\hline 2 & Sand \& Gravel & $\mathrm{m3}$ & 470 & & 707 & 332290 & 7551,02 \\
\hline 3 & Stone & $\mathrm{m} 3$ & 280 & & 707 & 197960 & 4498,48 \\
\hline 4 & G I Wire & $\mathrm{kg}$ & 1040 & & 50 & 52000 & 1181,66 \\
\hline 5 & Steel bar & $\mathrm{kg}$ & 1680 & & 50 & 84000 & 1908,83 \\
\hline 6 & Hand pump set & set & 100 & & 14500 & 1450000 & 32950,05 \\
\hline 7 & Plastic Rope $7 \mathrm{~mm}$ & $\mathrm{~kg}$ & 150 & & 80 & 12000 & 272,69 \\
\hline 8 & clamp & nos & 1000 & & 24 & 24000 & 545,38 \\
\hline 9 & Jointing Solution & $\mathrm{kg}$ & 15 & & 200 & 3000 & 68,17 \\
\hline 10 & Raising Main & $m$ & 3000 & & 120 & 360000 & 8180.70 \\
\hline \multirow[t]{3}{*}{11} & Transport cost & Lumpsum & & & & 168000 & 3817,66 \\
\hline & Sub-total & & & & & 3170750 & 72052,67 \\
\hline & \multicolumn{7}{|c|}{2 - Non-expendable Material } \\
\hline 12 & Ring mould & nos & 24 & & 1800 & 43200 & 981,68 \\
\hline 13 & Post Mouid & nos & 8 & & 800 & 6400 & 145.43 \\
\hline 14 & Top ring mould & nos & 8 & & 2000 & 16000 & 363,59 \\
\hline 15 & Field Camp Equipment & set & 6 & & 5000 & 30000 & 681,73 \\
\hline 16 & Water pump & nos. & 3 & & 17000 & 51000 & 1158,93 \\
\hline \multirow[t]{3}{*}{17} & Small Toois & lot & 24 & & 100 & 2400 & 54,54 \\
\hline & Sub-total & & & & & 149000 & 3385,90 \\
\hline & 3 -Labor & & & & & & \\
\hline 18 & Skilled Labor & $\mathrm{m} / \mathrm{d}$ & 300 & & 200 & 60000 & 1363,45 \\
\hline \multirow[t]{3}{*}{19} & Unskilled Labor & $\mathrm{m} / \mathrm{d}$ & 1400 & & 85 & 119000 & 2704,18 \\
\hline & Sub-total & & & & & 179000 & 4067,63 \\
\hline & 4-Personnel & & & & & & \\
\hline 20 & Site Engineer & & 3 & 4 & 5000 & 60000 & 1363,45 \\
\hline 21 & Foreman & & 3 & 4 & 3000 & 36000 & 818,07 \\
\hline \multirow[t]{2}{*}{22} & Guards & & 6 & 4 & 1500 & 36000 & 818,07 \\
\hline & Sub-total & & & & & 132000 & 2999,59 \\
\hline UB-T & OTAL WELLS IN BA & H PROV & & & & 3630750 & 82505,79 \\
\hline
\end{tabular}

\subsection{SURFACE LATRINES 200 Latrines}

1 - Expendable Material

$\begin{array}{lcc}\text { Cement } & \text { bag } & 600 \\ \text { Sand \& Gravel } & \mathrm{m3} & 66,8 \\ \text { Stone } & \mathrm{m3} & 600 \\ \text { Soil } & \mathrm{m} 3 & 240 \\ \text { Steel bar } & \mathrm{kg} & 1304 \\ \text { Bending Wire } & \mathrm{kg} & 100 \\ \text { Wooden Bar 2m } & \text { nos } & 1800 \\ \text { Wooden Plank } & \text { nos } & 1000 \\ \text { Chute } & \mathrm{m} & 600 \\ \text { CPV Pipe + Screen Wire } & \mathrm{m} & 1200 \\ \text { Nail } & \mathrm{kg} & 100 \\ \text { Transport cost } & \text { Lumpsum } \\ \text { Sub-total } & & \end{array}$

$\begin{array}{rrr}325 & 195000 & 4431,21 \\ 707 & 47228 & 1073,21 \\ 707 & 424200 & 9639,59 \\ 290 & 69600 & 1581,60 \\ 50 & 65200 & 1481,62 \\ 50 & 5000 & 113,62 \\ 144 & 259200 & 5890,11 \\ 150 & 150000 & 3408,63 \\ 37 & 22200 & 504,48 \\ 115 & 138000 & 3135,94 \\ 50 & 5000 & 113,62 \\ & 258400 & 5871,93\end{array}$

2 - Non-expendable Material 


\begin{tabular}{|c|c|c|c|c|c|c|c|}
\hline Nom & DTEN S & Unit & Nimiber & Niontis & Initcost & R. & 155 \\
\hline \multirow[t]{3}{*}{13} & Toois & Lumpsum & & & & 19600 & 445,39 \\
\hline & Sub-total & & & & & 19600 & 445,39 \\
\hline & 3 -Labor & & & & & & \\
\hline 14 & Skilled Labor & $\mathrm{m} / \mathrm{d}$ & 1200 & & 200 & 240000 & 5453,80 \\
\hline \multirow[t]{3}{*}{15} & Unskilled Labor & $\mathrm{m} / \mathrm{d}$ & 200 & & 85 & 17000 & 386,31 \\
\hline & Sub-total & & & & & 257000 & 5840,11 \\
\hline & 4 -Personnel & & & & & & \\
\hline 16 & Site Engineer & & 2 & 4 & 5000 & 40000 & 908,97 \\
\hline 17 & Foreman & & 4 & 4 & 3000 & 48000 & 1090,76 \\
\hline \multirow[t]{2}{*}{18} & Guards & & 2 & 4 & 1500 & 12000 & 272,69 \\
\hline & Sub-total & & & & & 100000 & 2272,42 \\
\hline \multicolumn{4}{|c|}{ SUB-TOTAL LATRINES IN BALKH PROVINCE } & & & 2015627,60 & 45803,47 \\
\hline \multicolumn{4}{|c|}{ TOTAL WATER SUPPLY AND SANITATION } & & & 5646378 & 128309,27 \\
\hline
\end{tabular}

\section{INFRASTRUCTURE}

3. 1 COMMUNITY BUILDINGS two Primary School Buildings in Khulm District

\begin{tabular}{|c|c|c|}
\hline \multicolumn{3}{|c|}{1 - Expendable Material } \\
\hline Stone & m3 & 246 \\
\hline Cement & bag & 422 \\
\hline Sand Gravel & $\mathrm{m} 3$ & 290 \\
\hline Burned Brick & nos & 328424 \\
\hline Soil & m3 & 290 \\
\hline Lime & $\mathrm{kg}$ & 15234 \\
\hline Gypsum & $\mathrm{kg}$ & 812 \\
\hline Marble Clod & $\mathrm{kg}$ & 524 \\
\hline Wooden bar $5 \mathrm{~m}$ & nos. & 292 \\
\hline Wooden bar $4 \mathrm{~m}$ & nos. & 228 \\
\hline Wooden bar $2 \mathrm{~m}$ & nos & 72 \\
\hline Wooden board & nos. & 2400 \\
\hline Straw & $\mathrm{kg}$ & 4180 \\
\hline Reed & bundle & 200 \\
\hline Glue & $\mathrm{kg}$ & 56 \\
\hline Oil paint & $\mathrm{kg}$ & 76 \\
\hline Powder paint & $\mathrm{kg}$ & 64 \\
\hline Nail & $\mathrm{kg}$ & 60 \\
\hline Glass 3mm & $\mathrm{m} 2$ & 112 \\
\hline Blot lock & nos. & 50 \\
\hline Hinges $3^{\prime \prime}$ & pair & 60 \\
\hline Hinges 4" & pair & 60 \\
\hline Window handle & pair & 84 \\
\hline Plastic & $m 2$ & 822 \\
\hline Wire screen & $m$ & 104 \\
\hline Chute & m & 48 \\
\hline Putty & $\mathrm{kg}$ & 6,38 \\
\hline Door /window & $m 2$ & 38 \\
\hline Door & $m^{2}$ & 48 \\
\hline window & $m 2$ & 100 \\
\hline \multicolumn{3}{|l|}{ Transport } \\
\hline \multicolumn{3}{|l|}{ Sub total } \\
\hline \multicolumn{3}{|c|}{2 - Non-expendable Material } \\
\hline Buckets & nos: & 10 \\
\hline Tatky & nos: & 10 \\
\hline
\end{tabular}

\begin{tabular}{|c|c|}
\hline 110700 & 2515,57 \\
\hline 137150 & 3116,62 \\
\hline 130500 & 2965,50 \\
\hline 525478 & 11941.06 \\
\hline 84100 & 1911.10 \\
\hline 45702 & 1038,54 \\
\hline 17864 & 405,94 \\
\hline 9432 & 214,33 \\
\hline 136656 & 3105,39 \\
\hline 96444 & 2191,61 \\
\hline 10368 & 235,60 \\
\hline 360000 & 8180,70 \\
\hline 12122 & 275,46 \\
\hline 800 & 18,18 \\
\hline 2800 & 63,63 \\
\hline 10260 & 233,15 \\
\hline 5120 & 116,35 \\
\hline 3000 & 68,17 \\
\hline 26880 & 610,83 \\
\hline 22500 & 511.29 \\
\hline 2100 & 47,72 \\
\hline 2100 & 47,72 \\
\hline 6720 & 152,71 \\
\hline 9864 & 224,15 \\
\hline 5200 & 118,17 \\
\hline 1776 & 40,36 \\
\hline 191 & 4.35 \\
\hline 32300 & 733,99 \\
\hline 40800 & 927,15 \\
\hline 75000 & 1704,31 \\
\hline 26380 & 599,46 \\
\hline 950308 & 44319,13 \\
\hline 700 & 15,91 \\
\hline 450 & 10.23 \\
\hline
\end{tabular}




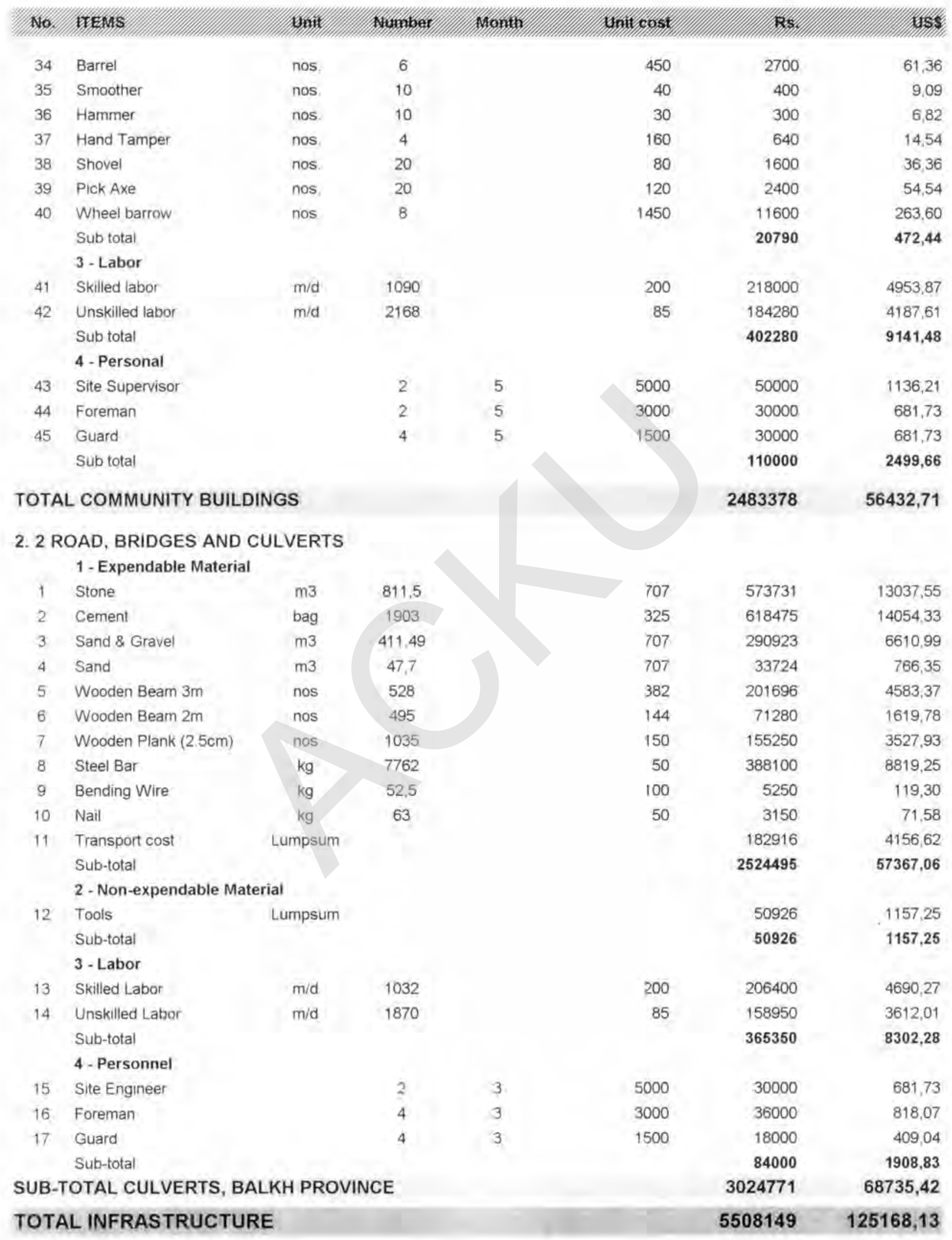




\section{AGRICULTURE}

3. 1 NURSERIES 5 Jenbs in Khuim District ( 85,000 saplings)

$\begin{array}{clccc}1 & \text { Land lease } & \text { Jerib } & 5 & 3 \\ 2 & \text { Seeds } & \text { Kg } & 100 & 1 \\ 3 & \text { Cultivation cost } & \text { Jerib } & 5 & 1 \\ 4 & \text { Animal fertilizer } & \text { Truck } & 10 & 1 \\ 5 & \text { Weeding } & \text { Time } & 5 & 5 \\ 6 & \text { Fertilizer (urea) } & \text { Bags } & 5 & 2 \\ 7 & \text { Fertilizer (DAP) } & \text { Bags } & 5 & 2 \\ 8 & \text { Pesticides } & \text { Lt./Kg } & 10 & 1 \\ 9 & \text { Sulfur } & \text { Bags } & 2 & 1 \\ 10 & \text { Grafting } & \text { Per tree } & 100000 & 1 \\ 11 & \text { Gardener } & \text { Person } & 3 & 24 \\ 12 & \text { Field supervisor } & \text { Person } & 1 & 24 \\ 13 & \text { Protection wall } & \text { Jerib } & 5 & 1 \\ 14 & \text { Tools } & \text { Set } & 5 & 1 \\ 15 & \text { Transportation cost } & \text { Lumpsum } & & \end{array}$

14300
150
3350
1500
2850
540
750
300
1000
1,3
2500
3000
10200
3000

TOTAL NURSERIES KHULM DISTRICT, BALKH PROVINCE

$$
\begin{array}{r}
214500 \\
15000 \\
16750 \\
15000 \\
71250 \\
5400 \\
7500 \\
3000 \\
2000 \\
130000 \\
180000 \\
72000 \\
51000 \\
15000 \\
7500
\end{array}
$$

805900

\section{0}

18313,41

4874,34 340,86

380,63

340,86

1619,10

122,71

170,43

68,17

45,45

2954,14

4090,35

1636,14

1158,93

340,86

170,43

18313,41

\section{SOCIAL WELFARE}

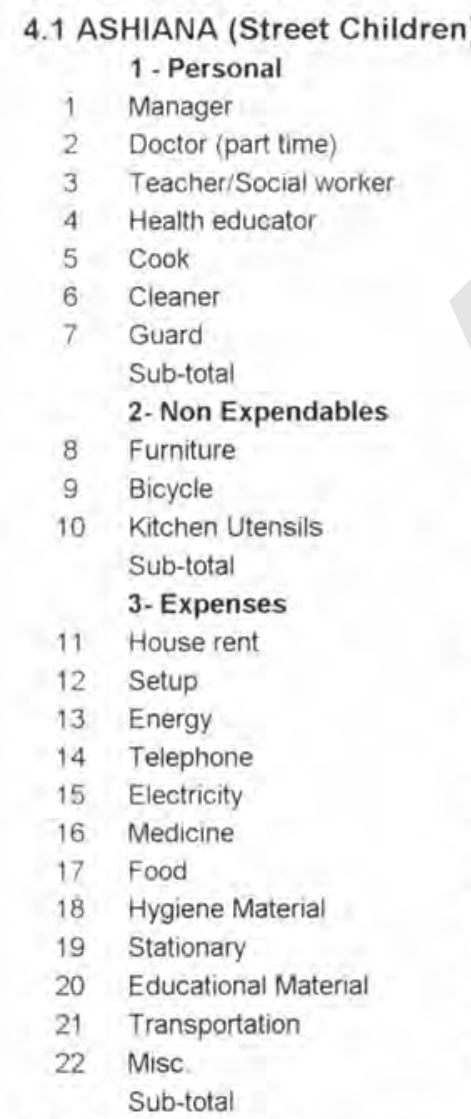

TOTAL ASHIANA

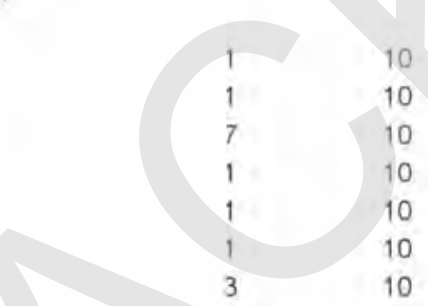

\section{0 \\ 2000 \\ 2500 \\ 2500 \\ 2000 \\ 1500 \\ 1500}

set

each

100000

3500

13000

month $\quad 10$

time

month

month

month

month

month

month

month

month

month

month
50000

20000

175000

25000

20000

15000

45000

350000

100000

14000

13000

127000

80000

10000

30000

2500

5000

18000

240000

40000

10000

10000

120000

20000

585500

1062500

1062500
1136.21

454.48

3976,73

568,10

454,48

340,86

1022,59

7953,46

2272,42

318,14

295,41

2885,97

1817.93

227.24

681,73

56,81

113,62

409,04

5453,80

908,97

227,24

227,24

2726,90

454,48

13305,00

24144,43

24144,43 


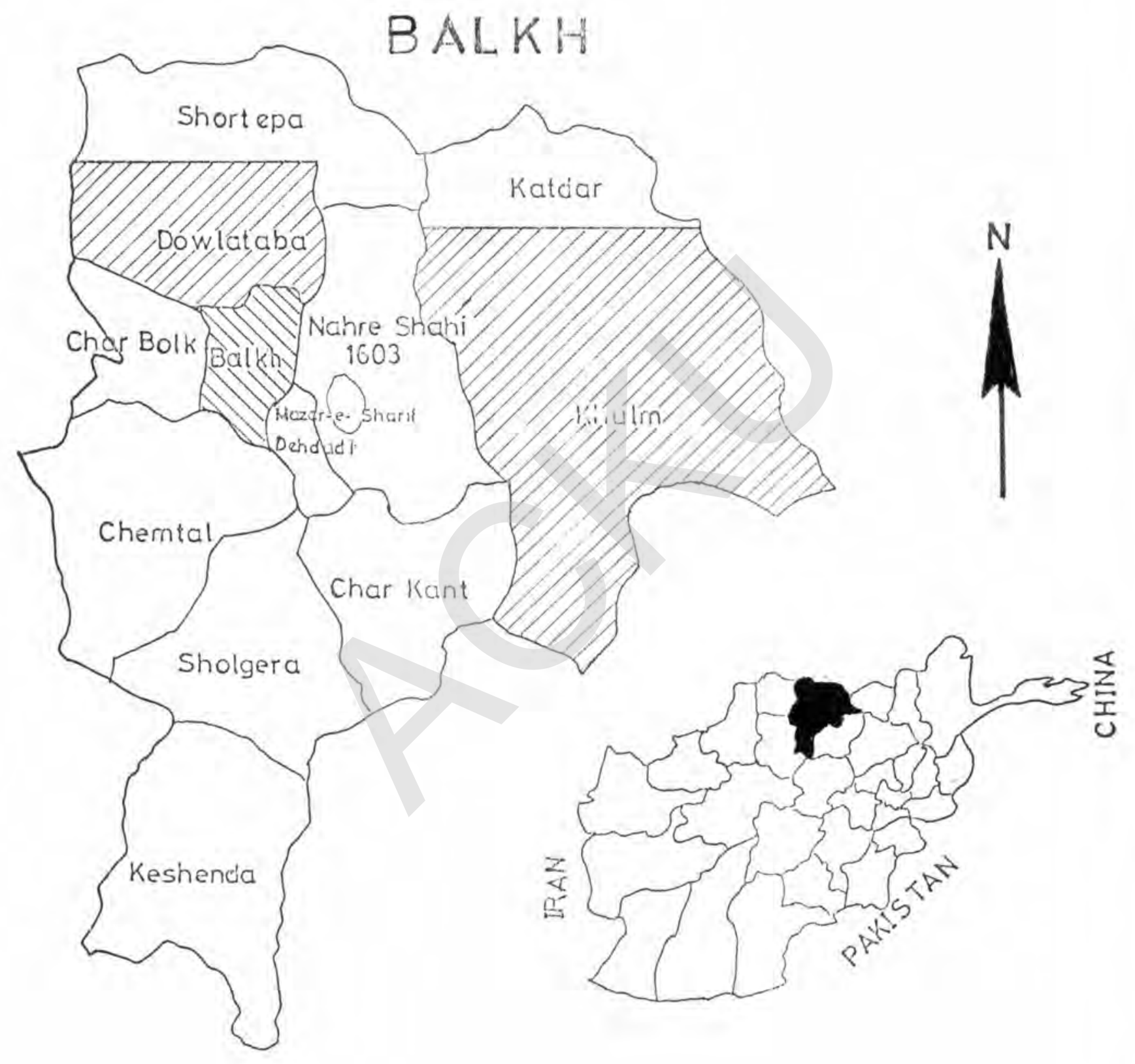




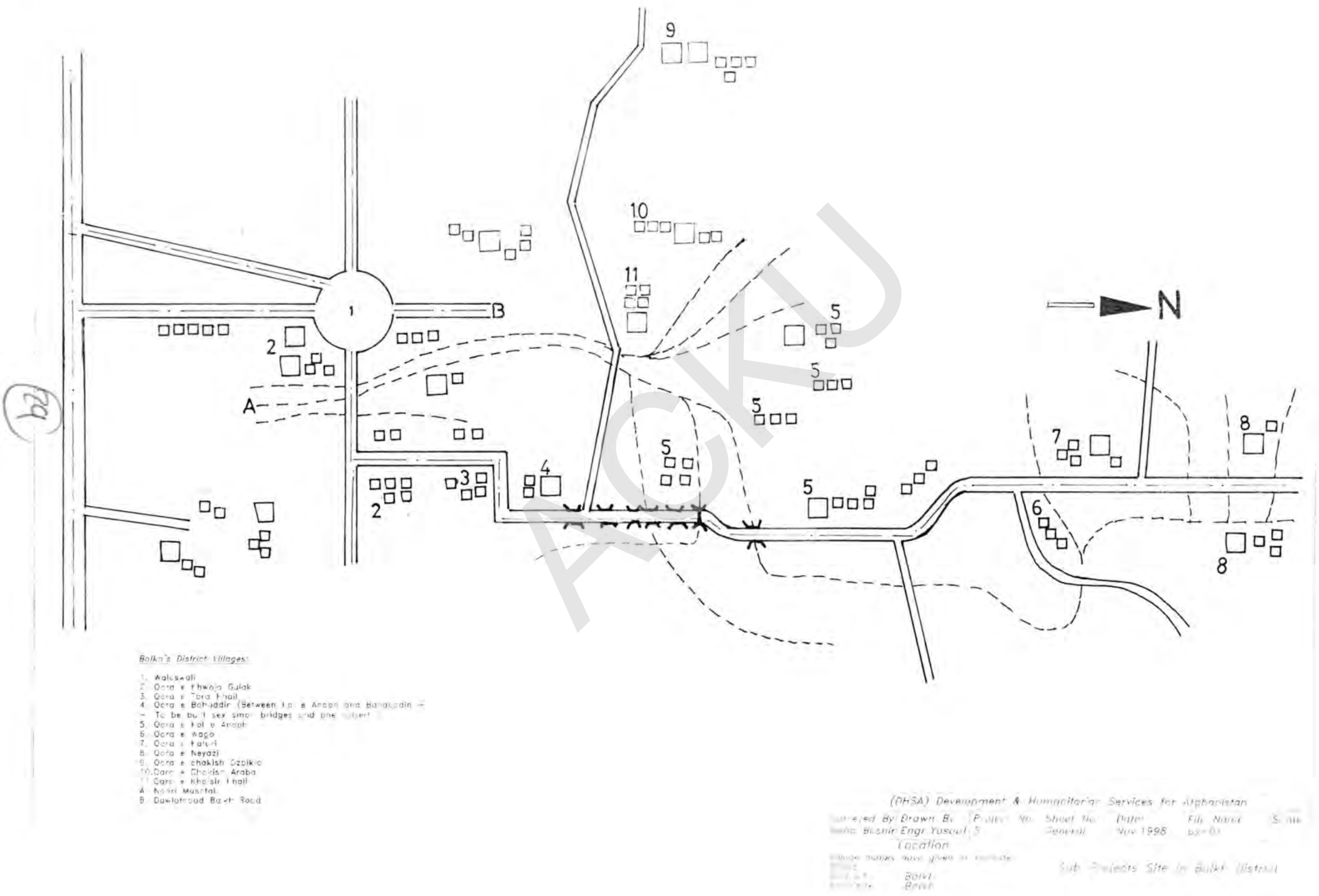




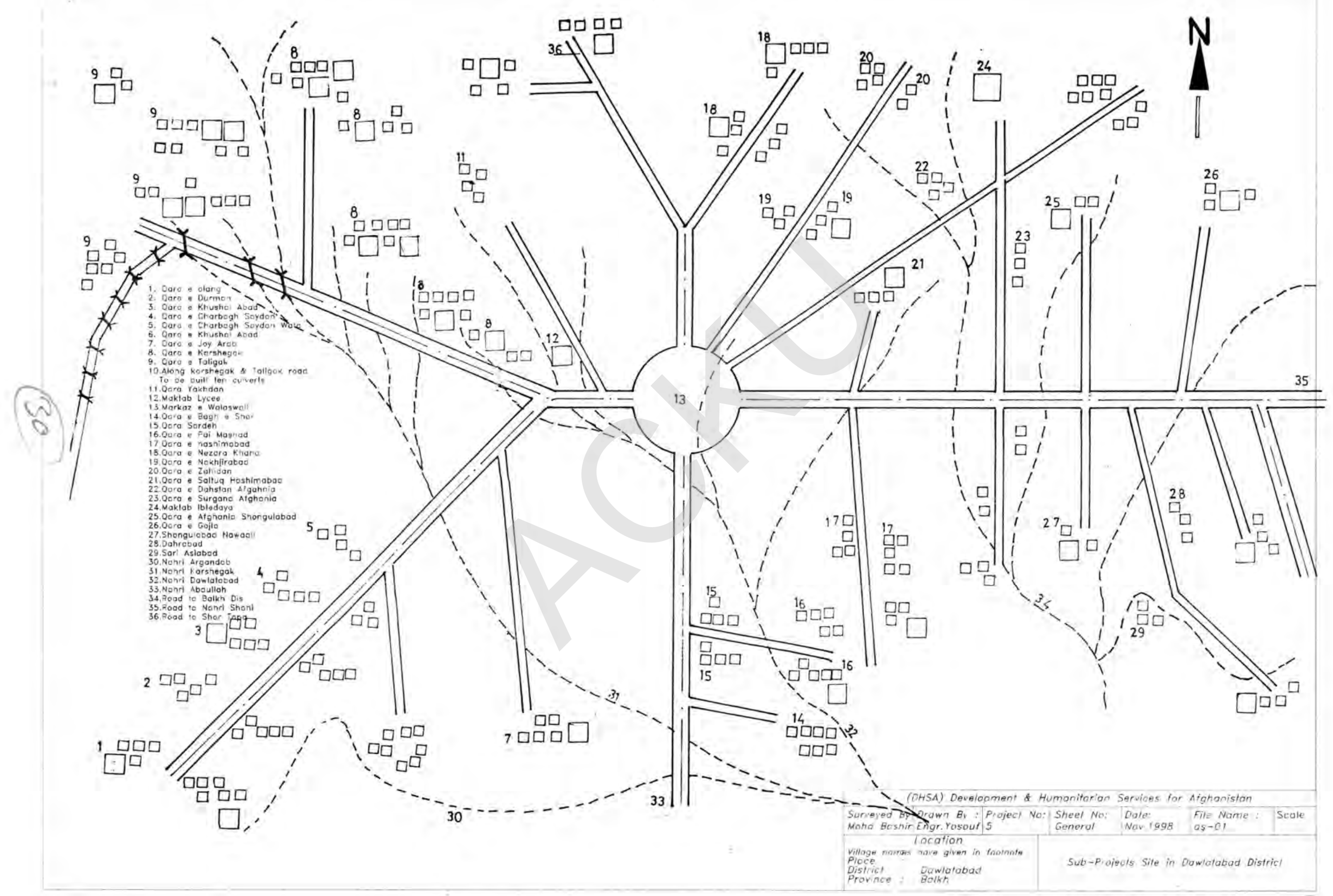




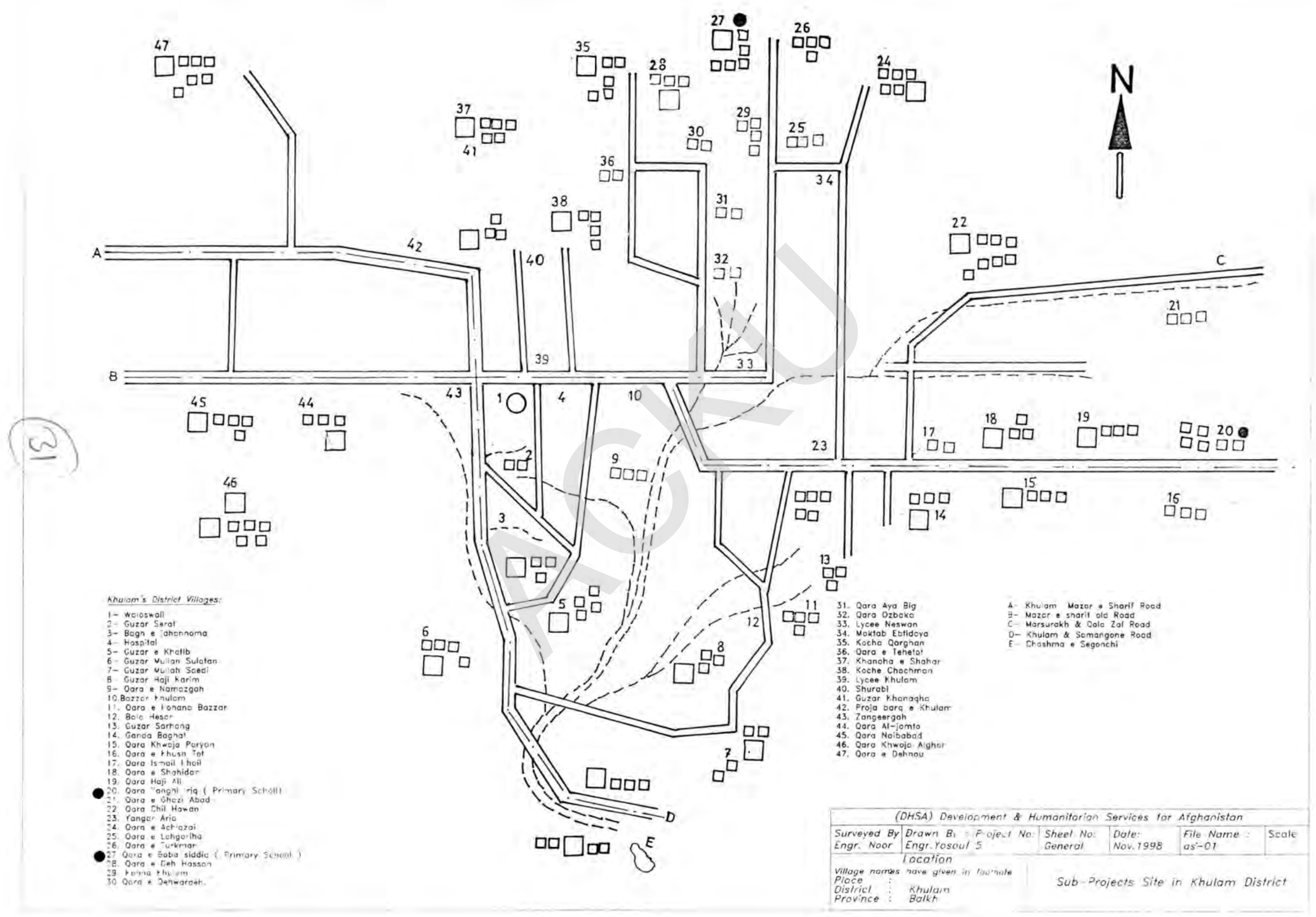


RURAL REHABILITATION AND URBAN SOCIAL PROGRAM IN NORTHERN AFGHANISTAN

Time Schedule

\begin{tabular}{|c|c|c|c|c|c|c|c|c|c|c|c|c|c|c|c|c|c|c|c|c|c|c|c|c|c|c|c|c|c|}
\hline \multirow{3}{*}{$\begin{array}{c}\text { Ser } \\
\text { Numb }\end{array}$} & \multirow{3}{*}{ Activities } & \multicolumn{4}{|c|}{1997} & \multicolumn{12}{|c|}{1998} & \multicolumn{12}{|c|}{1999} \\
\hline & & 0 & 0 & \begin{tabular}{l|l}
0 \\
\end{tabular} & 0 & 0 & \begin{tabular}{l|l|}
0 \\
\end{tabular} & \begin{tabular}{l|l|l|}
0 & \\
\end{tabular} & 11 & \begin{tabular}{|l|l}
2 & \\
\end{tabular} & \begin{tabular}{l|l}
3 & \\
\end{tabular} & 4 & \begin{tabular}{|l|l}
5 & \\
\end{tabular} & 6 & $7 \mid$ & \begin{tabular}{|l|l|}
8 \\
\end{tabular} & 9 & \begin{tabular}{|l|}
10 \\
\end{tabular} & 111 & \begin{tabular}{|l|}
12 \\
\end{tabular} & \begin{tabular}{|l|l|}
13 \\
\end{tabular} & 14 & 15 & \begin{tabular}{l|l}
16 & 1
\end{tabular} & 17 & \begin{tabular}{|c|c|}
18 & \\
\end{tabular} & 01 & 0 & 0 \\
\hline & & Sep & Oct & Nov & Dec & Jan & Feb & Màr & Apr & May & Jun - & Juil & Augs & Sep & Oct & Nov & Ded & $\operatorname{Jan}$ & Feb & & Apri & May, & & & & & & & Ded \\
\hline 1 & Needs Assessment (PRA) & & & & & & & & & & & & & & & & & & & & & & & & & & & & \\
\hline 2 & Surveys & & & & & & & & & & & & & & & & & & & & & & & & & & & & \\
\hline 3 & Technical Designs and Estimations & & & & & & & & & & & & & & & & & & & & & & & & & & & & \\
\hline 4 & Submitting for UN Appeal & & & & & & & & & & & & & & & & & & & & & & & & & & & & \\
\hline 5 & Preparing and submission of proposal & & & & & & & & & & & & & & & & & & & & & & & & & & & & \\
\hline 6 & Project proposed started date & & & & & & & & & & & & & & & & & & & & & & & & & & & & \\
\hline 7 & Organization of management and implementing plan & & & & & & & & & & & & & & & & & & & & & & & & & & & & \\
\hline 8 & Workshops/Training & & & & & & & & & & & & & & & & & & & & & & & & & & & & \\
\hline 9 & Nursery establishment and routine work & & & & & & & & & & & & & & & & & & & & & & & & & . & & & \\
\hline 10 & Well cleaning and Hand pump installation work & & & & & & & & & & & & & & & & & & & & & & & & & & & & \\
\hline 11 & Latrines Construction & & & & & & & & & & & & & & & & & & & & & & & & & & & & \\
\hline 12 & Implementation of Bridge and Culverts & & & & & & & & & & & & & & & & & & & & & & & & & & & & \\
\hline 13 & Community Buildings construction & & & & & & & & & & & & & & & & & 田 & & & & & & & & & & & \\
\hline 14 & Internal Monitoring & & & & & & & & & & & 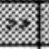 & $\sqrt{3}$ & & 2, & . & & $\sqrt{10}$ & 桨 & & 1.8 & 2.8 & & 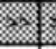 & 3. & & & & \\
\hline 15 & Review of the current year activity and making decision accordingly & & & & & & & & & & & & & & & & & & & & & & & & & & & & \\
\hline 16 & Financial and Technical Report & & & & & & & & & & & & & & & & & & & & & & & & & & & & \\
\hline 17 & External evaluation & & & & & & & & & & & & & & & & & & & & & & & & & & & & \\
\hline 18 & Audit & & & & & & & & & & & & & & & & & & & & & & & & & & & & \\
\hline
\end{tabular}




\section{RURAL REHABILITATION AND URBAN SOCIAL PROGRAM IN NORTHERN AFGHANISTAN}

SUMMARY OF PLANNED ACTIVITY IN PROJECT AREA (18 months 1998-99)

\begin{tabular}{|c|c|c|c|c|c|c|c|}
\hline No & PROJECT & TYPE & DISTRICT & PROVINCE & EXPMTRL & NON EXP & PERSONNEY TOTAL USS \\
\hline
\end{tabular}

1.WATER SUPPLY AND SANITATION

1.1 Wells Repair and Hand Pumps installation (100 wells)

\begin{tabular}{|r|l|l|l|l|l|l|r|r|r|}
\hline 3 & 45 Wells & HP + Well Repair & Balkh & Balkh & 32423,70 & 1523,66 & 1830,43 & 1349,82 & 37127,61 \\
\hline 4 & 55 Wells & HP + Well Repair & Dawlatabad & Balkh & 39628,97 & 1862,25 & 2237,20 & 1649,77 & 45378,18 \\
\hline \multicolumn{3}{|c|}{ Total } & 72052,67 & $\mathbf{3 3 8 5 , 9 0}$ & $\mathbf{4 0 6 7 , 6 3}$ & $\mathbf{2 9 9 9 , 5 9}$ & $\mathbf{8 2 5 0 5 , 7 9}$ \\
\hline
\end{tabular}

1.2 Surface Latrines

\begin{tabular}{|r|l|l|l|l|r|r|r|r|r|}
\hline 1 & Qariae Qarshigak (100) & Latrine Construction & Dawlatabad & Balkh & 18622,78 & 222,70 & 2920,06 & 1136,21 & 22901,74 \\
\hline 2 & QariaTligak (100) & Latrine Construction & Dawlatabad & Balkh & 18622,78 & 222,70 & 2920,06 & 1136,21 & 22901,74 \\
\hline \multicolumn{3}{|c|}{ Total } & $\mathbf{3 7 2 4 5 , 5 5}$ & $\mathbf{4 4 5 , 3 9}$ & $\mathbf{5 8 4 0 , 1 1}$ & $\mathbf{2 2 7 2 , \mathbf { 4 2 }}$ \\
\hline
\end{tabular}

\section{INFRASTRUCTURE}

2.1 Community building

\begin{tabular}{|c|c|c|c|c|c|c|c|c|c|}
\hline 1 & Qanae Baba Seddiq & Primary School & Khulm & Balkh & 22159,57 & 236,22 & 4570,74 & 1249,83 & 28216.36 \\
\hline 2 & Qariae Yangı Areq & Primary School & Khuim & Balkh & 22159,57 & 236,22 & 4570,74 & 1249,83 & 28216,36 \\
\hline & & Total & & & 44319,13 & 472,44 & 9141,48 & 2499,66 & 56432,71 \\
\hline
\end{tabular}

2.2 Bridge and Culverts

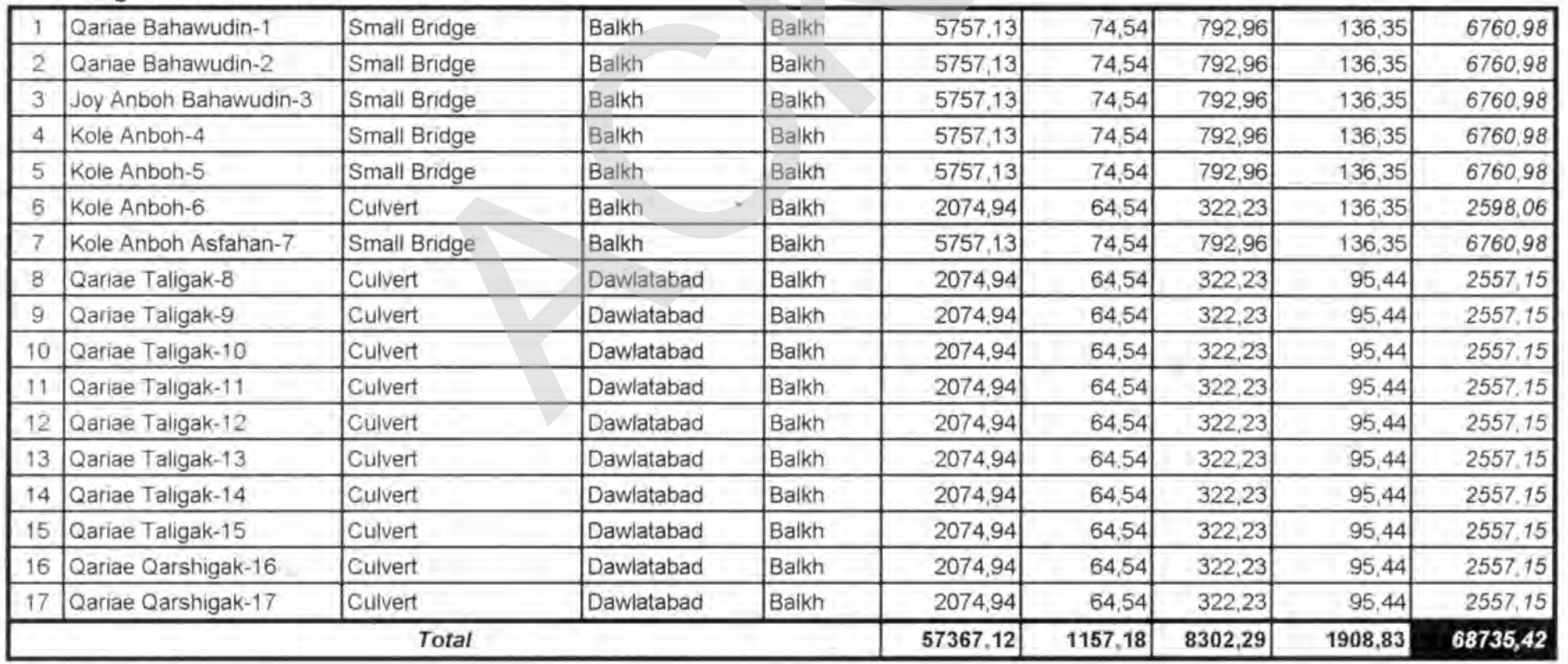

3. AGRICULTURE

3.1 Fruit tree nurseries

\begin{tabular}{|l|l|l|l|l|r|r|r|r|}
\hline 1 & 1 hectare & Fruit Trees Nursery & Khulm & Balkh & 12246,06 & 340,86 & & 5726,49 \\
\hline \multicolumn{2}{|c|}{ Total } & 18313,41 \\
\hline
\end{tabular}

4. SOCIAL WELFARE

4.1 Ashiana (Street Children)

\begin{tabular}{|c|c|c|c|c|c|c|c|c|}
\hline 1 & Wool Spinning & Ashiana & Mazare Sharif & Balkh & 13305,00 & 2885,97 & 7953,46 & 24144.43 \\
\hline \multicolumn{5}{|c|}{ Total } & 13305,00 & 2885,97 & 7953,46 & 24144,43 \\
\hline
\end{tabular}




\section{Well Cleaning and Hand Pump Installation}

Cost of one well in Balkh province

\begin{tabular}{|c|c|c|c|c|c|}
\hline Description & Unit: & Quantitys & Unit coste & Total Rs. & uss \\
\hline \multicolumn{6}{|c|}{1 - Expendable : General } \\
\hline Cement & bag & 15 & 325 & 4875 & 110,78 \\
\hline Sand \& Gravel & $\mathrm{m}^{3}$ & 4,7 & 707 & 3323 & 75,51 \\
\hline Stone & $\mathrm{m}^{3}$ & 2,8 & 707 & 1980 & 44,98 \\
\hline G. I. Wire & $\mathrm{kg}$ & 10,4 & 50 & 520 & 11,82 \\
\hline Steel bar & $\mathrm{kg}$ & 16,8 & 50 & 840 & 19,09 \\
\hline Hand pump set & set & 1 & 14500 & 14500 & 329,50 \\
\hline Plastic Rope $7 \mathrm{~mm}$ & $\mathrm{~kg}$ & 1,5 & 80 & 120 & 2,73 \\
\hline Clamp & nos & 10 & 24 & 240 & 5,45 \\
\hline Jointing Solution & $\mathrm{kg}$ & 0,15 & 200 & 30 & 0,68 \\
\hline Raising Main & $m$ & 30 & 120 & 3600 & 81,81 \\
\hline Transport cost & Lumpsum & $\rightarrow$ & & 1680 & 38,17 \\
\hline \multicolumn{4}{|l|}{ Sub-total } & 31707 & 720,52 \\
\hline \multicolumn{6}{|c|}{2 - Non-expendable Material } \\
\hline Ring mould & nos & 0,24 & 1800 & 432 & 9,82 \\
\hline Post Mould & nos & 0,08 & 800 & 64 & 1.45 \\
\hline Top ring mould & nos & 0,08 & 2000 & 160 & 3,64 \\
\hline Field Camp Equipment & set. & 0,06 & 5000 & 300 & 6,82 \\
\hline Water pump & nos & 0,03 & 17000 & 510 & 11.59 \\
\hline Small Tools & lot & 0,24 & 100 & 24 & 0,55 \\
\hline \multicolumn{4}{|l|}{ Sub-total } & 1490 & 33,86 \\
\hline \multicolumn{6}{|l|}{3 -Labor } \\
\hline Skilled Labor & $\mathrm{m} / \mathrm{d}$ & 3 & 200 & 600 & 13,63 \\
\hline Unskilled Labor & $\mathrm{m} / \mathrm{d}$ & 14 & 85 & 1190 & 27,04 \\
\hline \multicolumn{4}{|l|}{ Sub-total } & 1790 & 40,68 \\
\hline
\end{tabular}

4- Personnel
\begin{tabular}{|l|c|c|r|r|r|}
\hline Site Engineer & Number & Months & 600 & 13,63 \\
\hline Foreman & 3 & 4 & 4 & 360 & 8,18 \\
\hline Guards & 6 & 4 & & 360 & 8,18 \\
\hline Sub-total & & & 1320 & 30,00 \\
\hline
\end{tabular}




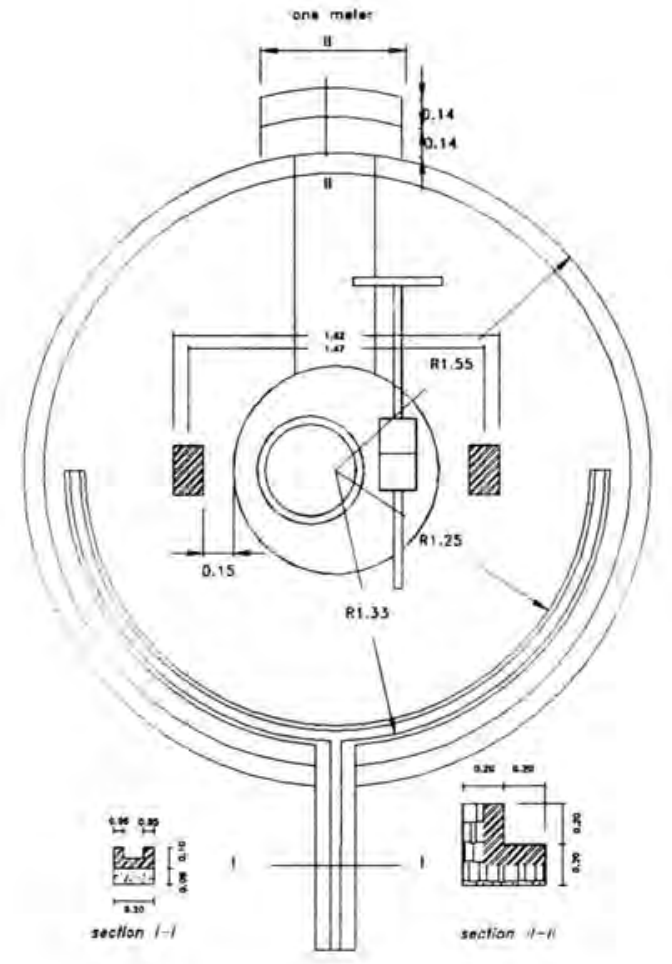

Apron in Plan
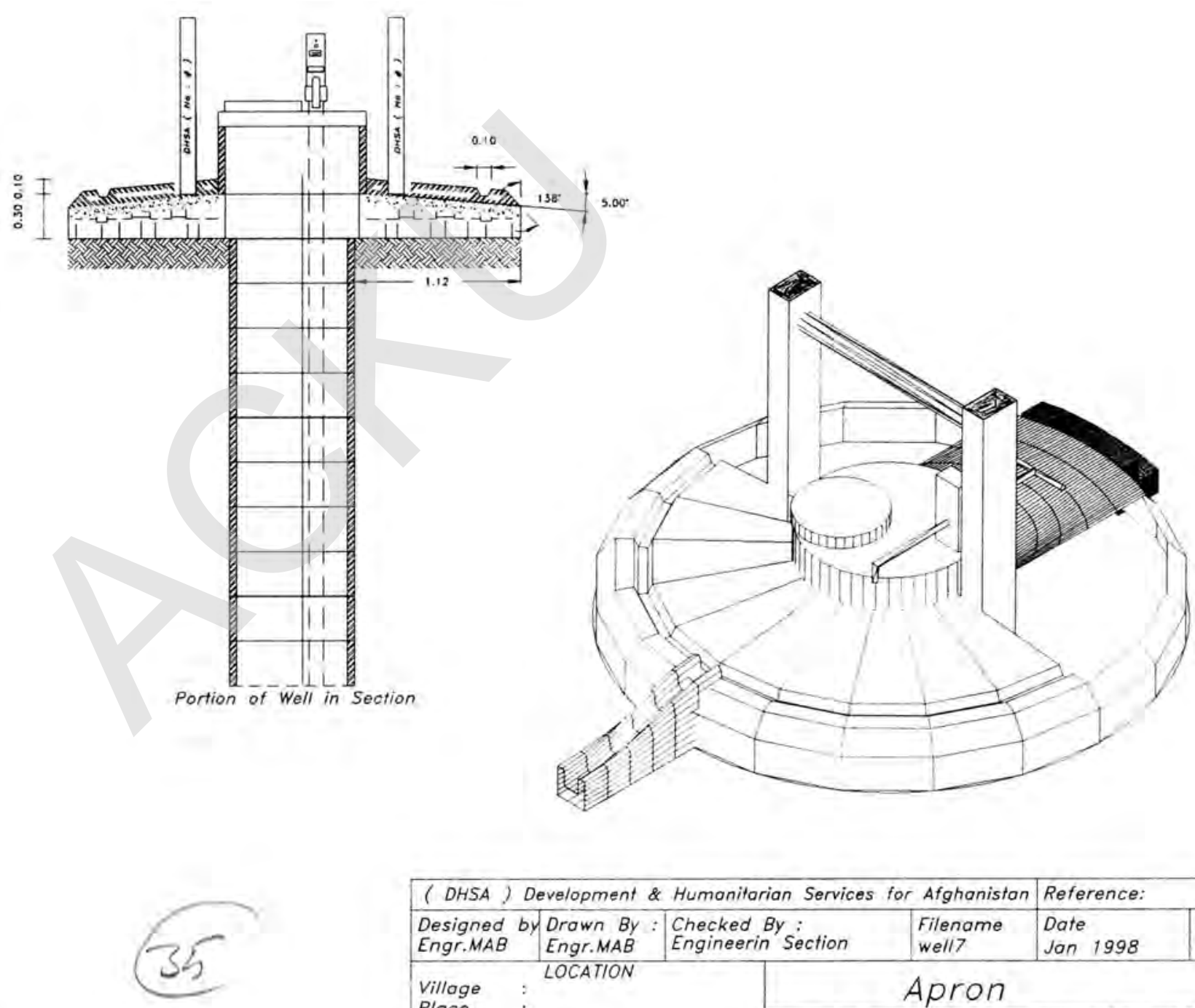

\begin{tabular}{|c|c|c|c|c|c|c|}
\hline \multirow{2}{*}{\multicolumn{2}{|c|}{$\begin{array}{l}\text { ( DHSA ) Development \& } \\
\begin{array}{l}\text { Designed by Drawn By : } \\
\text { Engr.MAB Engr.MAB }\end{array}\end{array}$}} & \multicolumn{2}{|c|}{ Humanitarian Services for Afghanistan } & \multicolumn{3}{|c|}{ Reference: } \\
\hline & & $\begin{array}{l}\text { Checked By : } \\
\text { Engineerin Section }\end{array}$ & $\begin{array}{l}\text { Filename } \\
\text { well7 }\end{array}$ & $\begin{array}{l}\text { Date } \\
\text { Jan } 1\end{array}$ & 1998 & $\begin{array}{l}\text { Scale } \\
1: 100\end{array}$ \\
\hline \multirow{2}{*}{$\begin{array}{l}\text { Village } \\
\text { Place } \\
\text { District } \\
\text { Province }\end{array}$} & \multicolumn{2}{|c|}{\begin{tabular}{l|l} 
LOCATION & \\
\end{tabular}} & \multicolumn{4}{|l|}{ Apron } \\
\hline & & Drawing & ber O01A & & Edition & Sheet \\
\hline
\end{tabular}


1. Diameter $95 \mathrm{~cm}$ inner dia \& $105 \mathrm{~cm}$ outer dia. (top ring) 2. Height

$48 \mathrm{~cm}$ ( Top ring only)

4. Three loops of $\mathrm{Gl}$ wire are used in each ring (weight $.5 \mathrm{~kg}$ )

5. About one bag of cement is needed to make three rings

6. Cement and gravel ration $(1: 2: 3)$
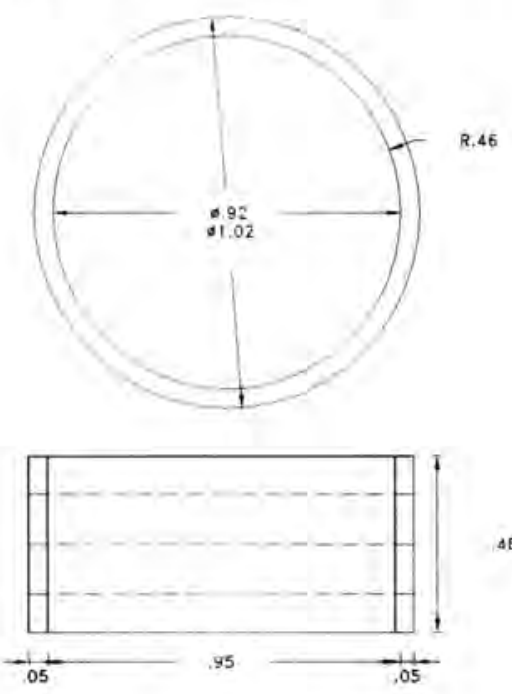

Dimension and specification:

\section{Concrete posts:}

1. Height 168 cross section $15 \times 20 \mathrm{~cm}$
2. Approximately one bag cement is required for three posts.
3. four iron bar ( $6 \mathrm{~mm} i \mathrm{~L}=158)$ are used in each post.
4. Cement. sand and gravel ratio $(1: 2: 4)$
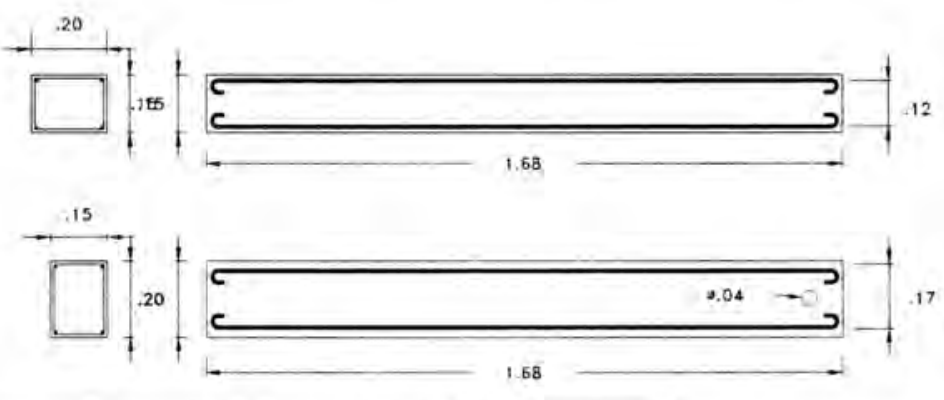

Isometric view of top ring and posts

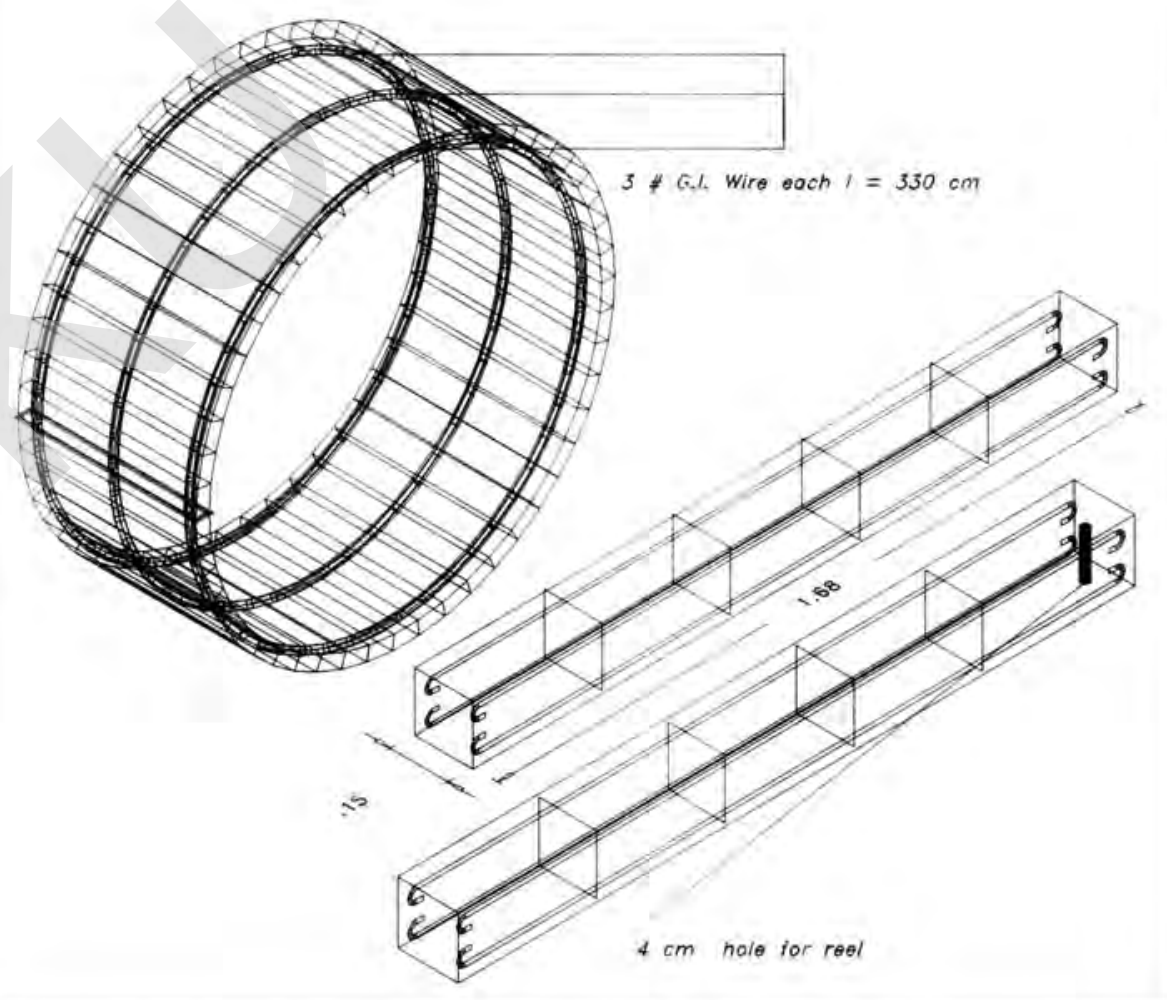

\begin{tabular}{|c|c|c|c|c|c|c|}
\hline \multicolumn{5}{|c|}{ ( DHSA ) Development \& Humanitarian Services for Afghanistan } & \multicolumn{2}{|l|}{ Reference: } \\
\hline $\begin{array}{l}\text { Designed } \\
\text { Engr.Mab }\end{array}$ & $\begin{array}{l}\text { by Drawn By : } \\
\text { Engr.MAB }\end{array}$ & $\begin{array}{l}\text { Checked } \\
\text { Engineer }\end{array}$ & By : & $\begin{array}{l}\text { Filename } \\
\text { wellot }\end{array}$ & $\begin{array}{l}\text { Date } \\
\text { Jan } 1998\end{array}$ & $\begin{array}{l}\text { Scale } \\
1: 100\end{array}$ \\
\hline \multirow{2}{*}{$\begin{array}{l}\text { Village } \\
\text { Place } \\
\text { District } \\
\text { Province }\end{array}$} & \multirow{2}{*}{\multicolumn{2}{|c|}{$\begin{array}{l}\text { LOCATION } \\
\text { Oarshegak } \\
\text { Qarshegak } \\
\text { Dawlatabad } \\
\text { Balkh }\end{array}$}} & \multicolumn{2}{|c|}{ Schedule of } & \multicolumn{2}{|c|}{ Bars } \\
\hline & & & Drawing & ber $001 \mathrm{~A}$ & Edition & $\begin{array}{l}\text { Sheet } \\
3 / 3\end{array}$ \\
\hline
\end{tabular}




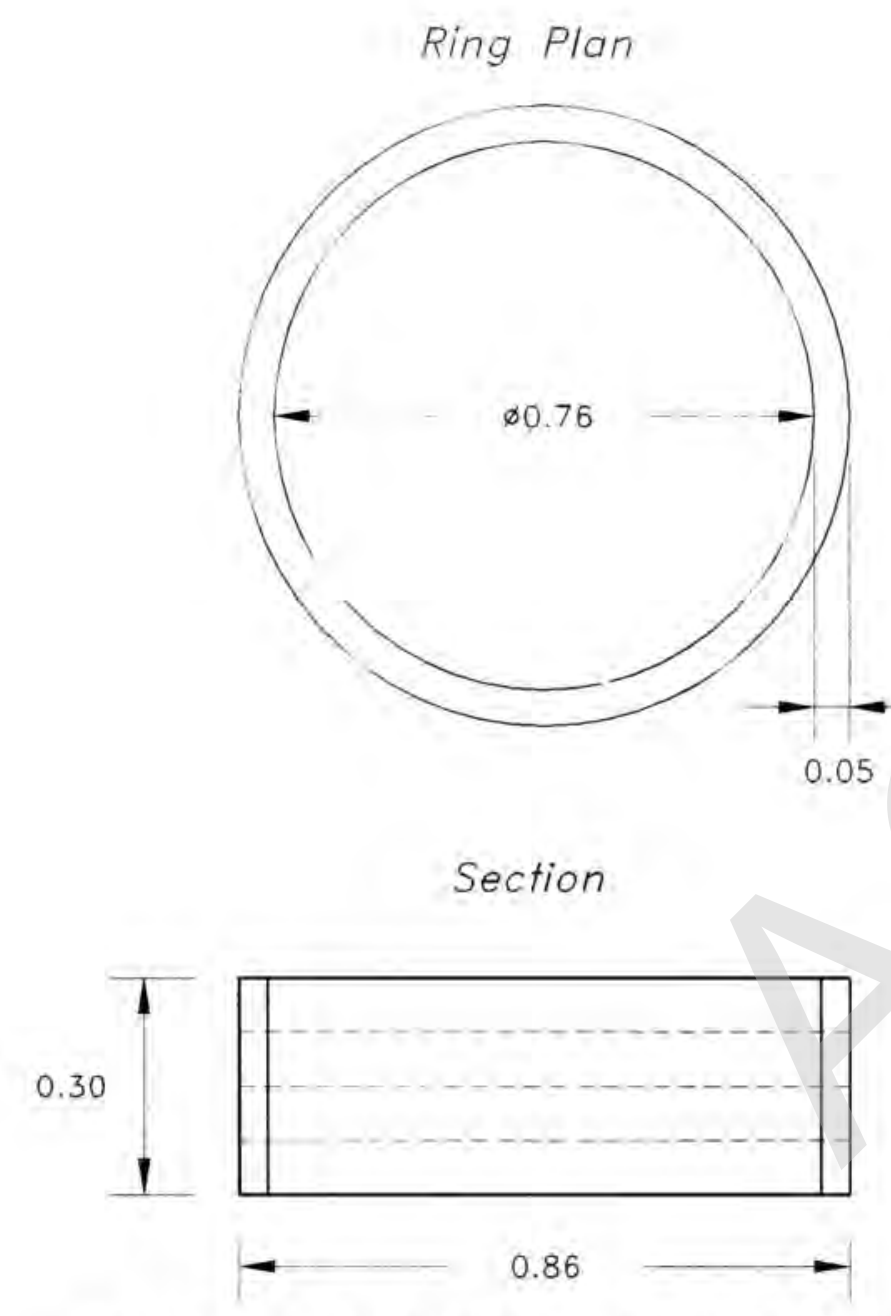

cement, sand and gravel ratio ( $1: 2: 3$ )

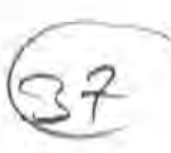

isometric view

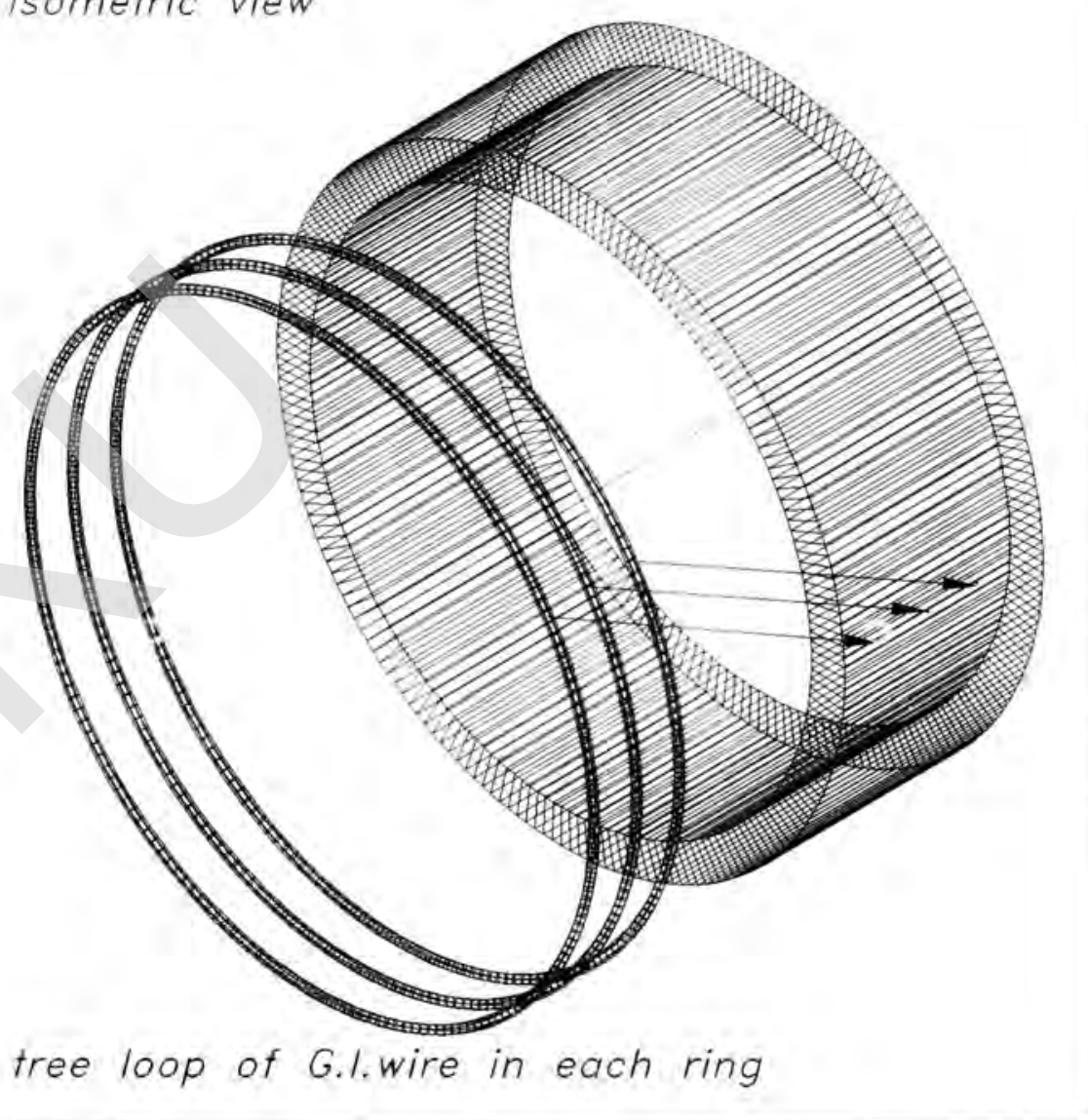

\begin{tabular}{|c|c|c|c|c|c|c|}
\hline \multirow{2}{*}{$\begin{array}{l}\text { (DHSA) } \\
\text { Designed } \\
\text { Engr.MAB }\end{array}$} & Development \& & \multicolumn{2}{|c|}{ Humanitorian Services } & for Afghanistan & \multicolumn{2}{|l|}{ Reference: } \\
\hline & $\begin{array}{c}\text { by } \begin{array}{c}\text { Drawn } B y \\
\text { Engr.MAB }\end{array}\end{array}$ & \multicolumn{2}{|c|}{$\begin{array}{l}\text { Checked By } \\
\text { Engineerin Section }\end{array}$} & $\begin{array}{l}\begin{array}{l}\text { Filename } \\
\text { wells }\end{array} \\
\end{array}$ & $\begin{array}{l}\text { Date } \\
\text { Jan } 1998\end{array}$ & $\begin{array}{l}\text { scale } \\
1: 100\end{array}$ \\
\hline \multirow{2}{*}{$\begin{array}{l}\text { Village } \\
\text { Place } \\
\text { District } \\
\text { Province }\end{array}$} & \multirow{2}{*}{$\begin{array}{l}\text { LOCATION } \\
\text { Qorstagok \& } \\
\text { Oarshegak \& } \\
\text { Dawliatabad } \\
\text { Balkh }\end{array}$} & \multirow{2}{*}{$\begin{array}{l}\text { Taligak } \\
\text { Taligak }\end{array}$} & \multicolumn{4}{|c|}{ Ring } \\
\hline & & & Drawing & $001 A$ & & $\begin{array}{l}\text { Sheet } \\
4 / 5\end{array}$ \\
\hline
\end{tabular}


Pedestal

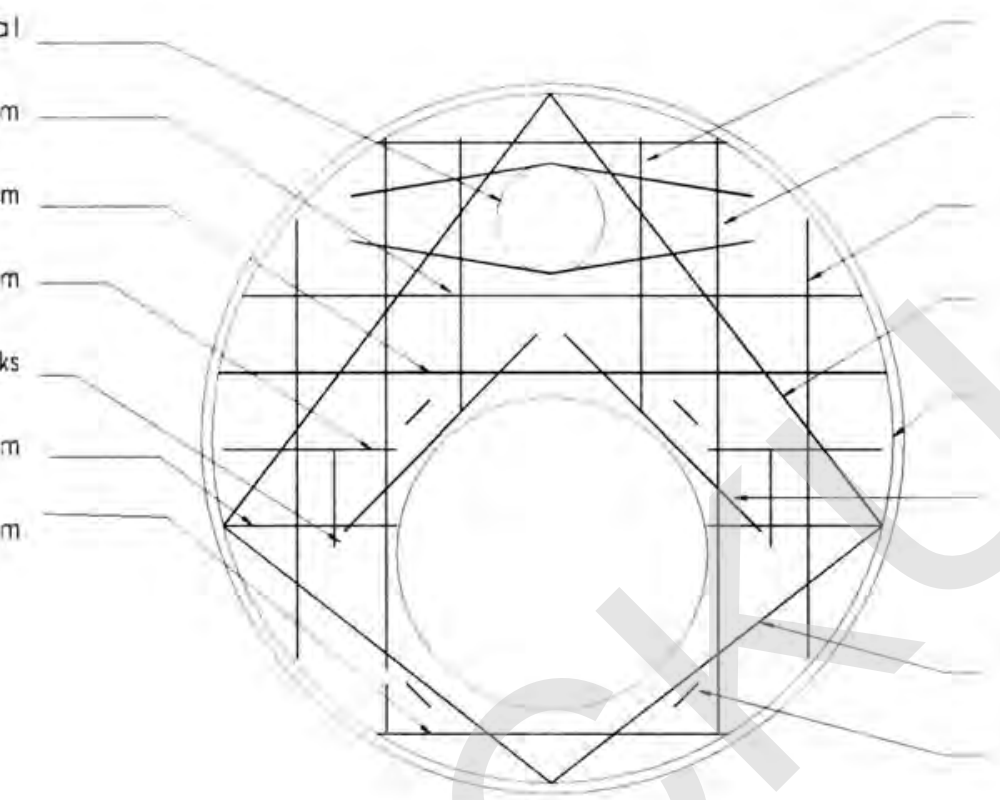

$1 \#$ cio $6 \mathrm{~mm} ; 1=100 \mathrm{~cm}$

2\#dia $6 \mathrm{~mm} ; 1=29 \mathrm{~cm}$

2f dic $6 \mathrm{~mm}$; handle hooks

$2 \#$ dia $6 \mathrm{~mm} ; 1=24 \mathrm{~cm}$

$2 \#$ dia $6 \mathrm{~mm}: 1=57 \mathrm{~cm}$

0.10

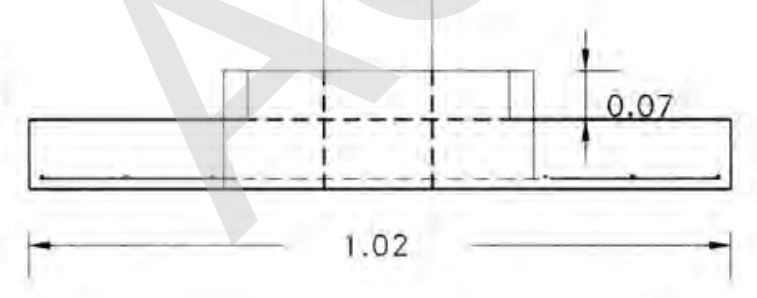

$1 \#$ dia $6 \mathrm{~mm}: 1=48 \mathrm{~cm}$

$2 \#$ dia $6 \mathrm{~mm} ; 1=89 \mathrm{~cm}$

2\#dia $6 \mathrm{~mm} ; 1=70 \mathrm{~cm}$

$2 \#$ dia $6 \mathrm{~mm} ; 1=85 \mathrm{~cm}$

1\#dia $6 \mathrm{~mm} ; 1=330 \mathrm{~cm}$

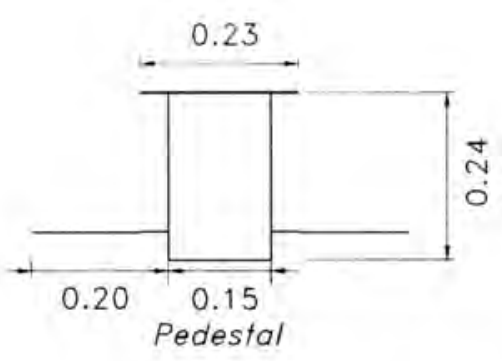

$2 \#$ dia $6 \mathrm{~mm}: 1=40 \mathrm{~cm}$

2\# dia $6 \mathrm{~mm} ; \mid=70 \mathrm{~cm}$

4fjio $6 \mathrm{~mm}$; honde hooks for boding

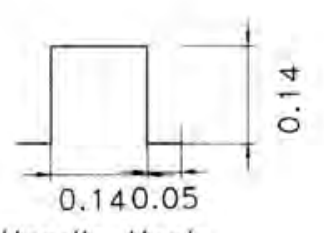

Handle Hook

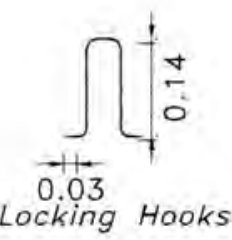

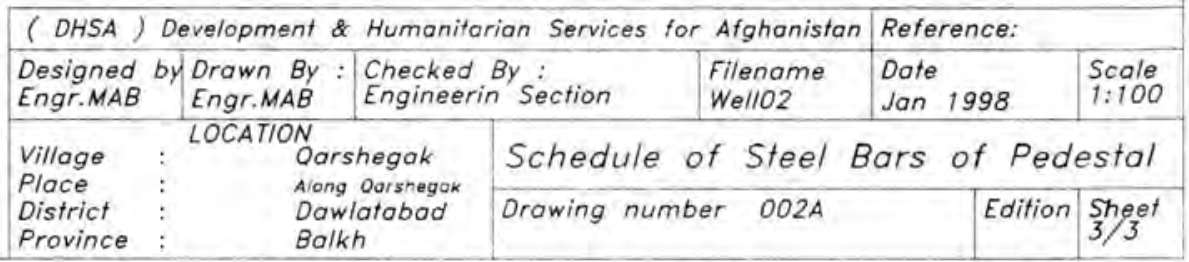



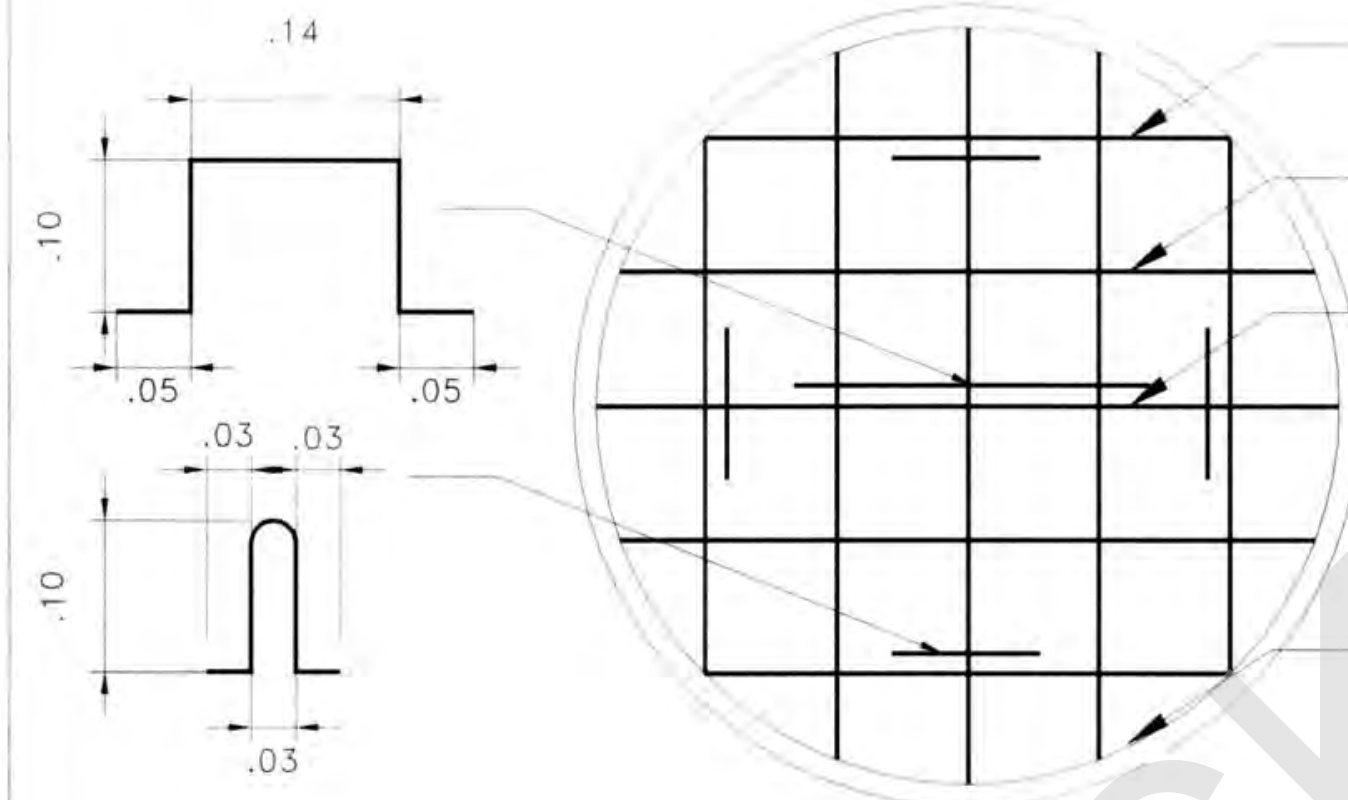

4 \#DA 6 MM : $L=35 \mathrm{CM}$

$4 A D / 4.6 M M: L=47 C M$

$2 \# D / A, E M M: L=51 \mathrm{CM}$

\# D/A . $6 M M, L=157 \mathrm{CM}$
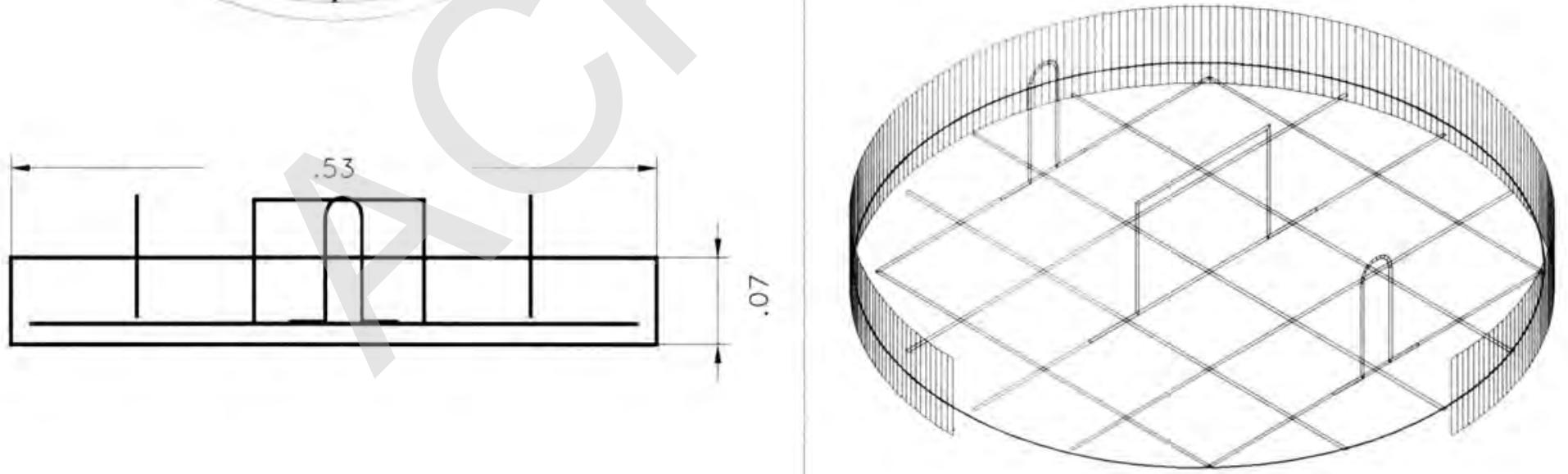

(DHSA) Development \& Humanitarian Services for Afghanistan Reference: \begin{tabular}{l|l|l|l|l|}
\hline $\begin{array}{l}\text { Designed by Drawn By: } \\
\text { Engr.MAB } \\
\text { Engr.MAB }\end{array}$ & $\begin{array}{l}\text { Checked By : } \\
\text { Engineerin Section }\end{array}$ & $\begin{array}{l}\text { Filename } \\
\text { well6 }\end{array}$ & $\begin{array}{l}\text { Date } \\
\text { Jan } 1998\end{array}$ & $\begin{array}{l}\text { Scale } \\
1: 100\end{array}$ \\
\hline
\end{tabular}

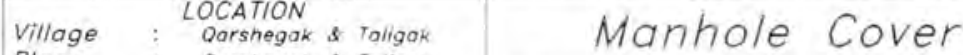

Place Qarshegak \& Taligo

District : Dawlatabad

Drawing number 001 

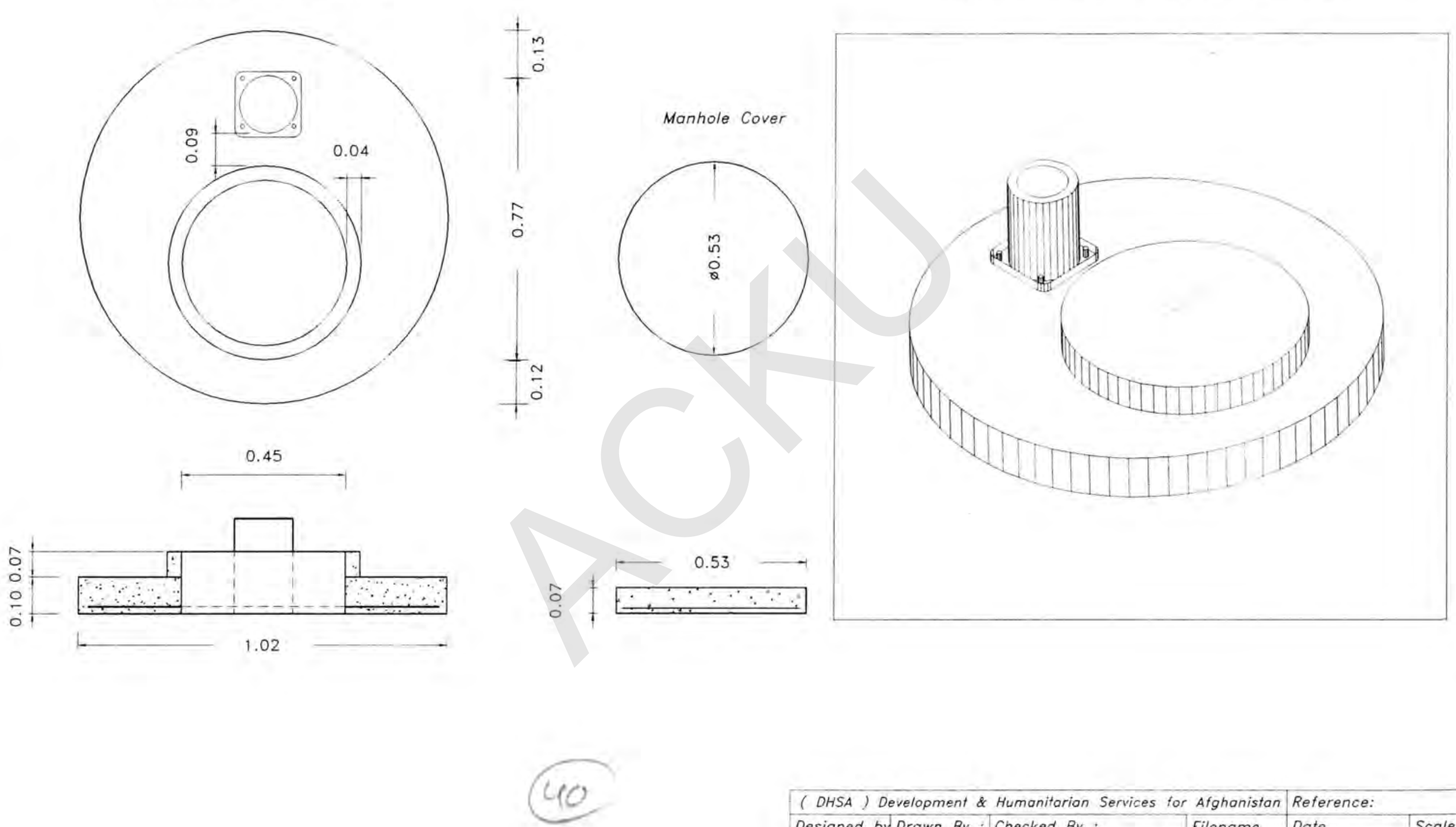

\begin{tabular}{|c|c|c|c|c|c|c|}
\hline \multicolumn{2}{|c|}{ ( DHSA ) Development \& } & \multicolumn{3}{|c|}{ Humanitarian Services for Afghanistan } & \multicolumn{2}{|c|}{ Reference: } \\
\hline $\begin{array}{l}\text { Designed } \\
\text { Engr.MAB }\end{array}$ & by $\begin{array}{l}\text { Drawn } B y \\
\text { Engr.MAB }\end{array}$ & $\begin{array}{l}\text { Check } \\
\text { Engin }\end{array}$ & By: & $\begin{array}{l}\text { Filename } \\
\text { wello4 }\end{array}$ & $\begin{array}{l}\text { Date } \\
\text { Jan } 199\end{array}$ & $\begin{array}{l}\text { Scale } \\
1: 100\end{array}$ \\
\hline \multirow{2}{*}{$\begin{array}{l}\text { Village } \\
\text { Place } \\
\text { District } \\
\text { Province }\end{array}$} & \multirow{2}{*}{\multicolumn{2}{|c|}{$\begin{array}{l}\text { LOCATION } \\
\text { Oorshego \& Toligat } \\
\text { Oorshegok \& Ialigox } \\
\text { Dawlatabad } \\
\text { Balkh }\end{array}$}} & \multicolumn{4}{|c|}{ Pedestal and Manhole Cover } \\
\hline & & & Drawing & $001 \mathrm{~A}$ & & $\begin{array}{l}\text { Sheet } \\
4 / 6\end{array}$ \\
\hline
\end{tabular}


The inadequate and unsanitary disposal of infected hirman feces lead to the contamination of ground and sources of water supplies. It rause group of diseases indinde cholera, spphoid and paratyphoid fevers, the dysentery's, infant diarnheas, hook nom disease, ascariasis bilhariasis and other similar intentestinal infections and infestation.

After execrate are disposed on the ground or in unsafe latrine with deep septic wells (pets) the bacteria, unable to more much by themselves, may be transported horizontally and downvard into the ground by leaching liquids or urine, or by raimuater.

Studies have shown that bacteria were traced to distance of 15 meters from the dosing well into which tested bacteria were introduced. Harmfiul bacteria may contaminate if ground water is located near a source of infected within the diastases mentioned above. Thus digging of shallow well should consider in allowed distance.

So DHSA in vien of scientific studies, never agree with septic well constructed near the water at least 40 meter.

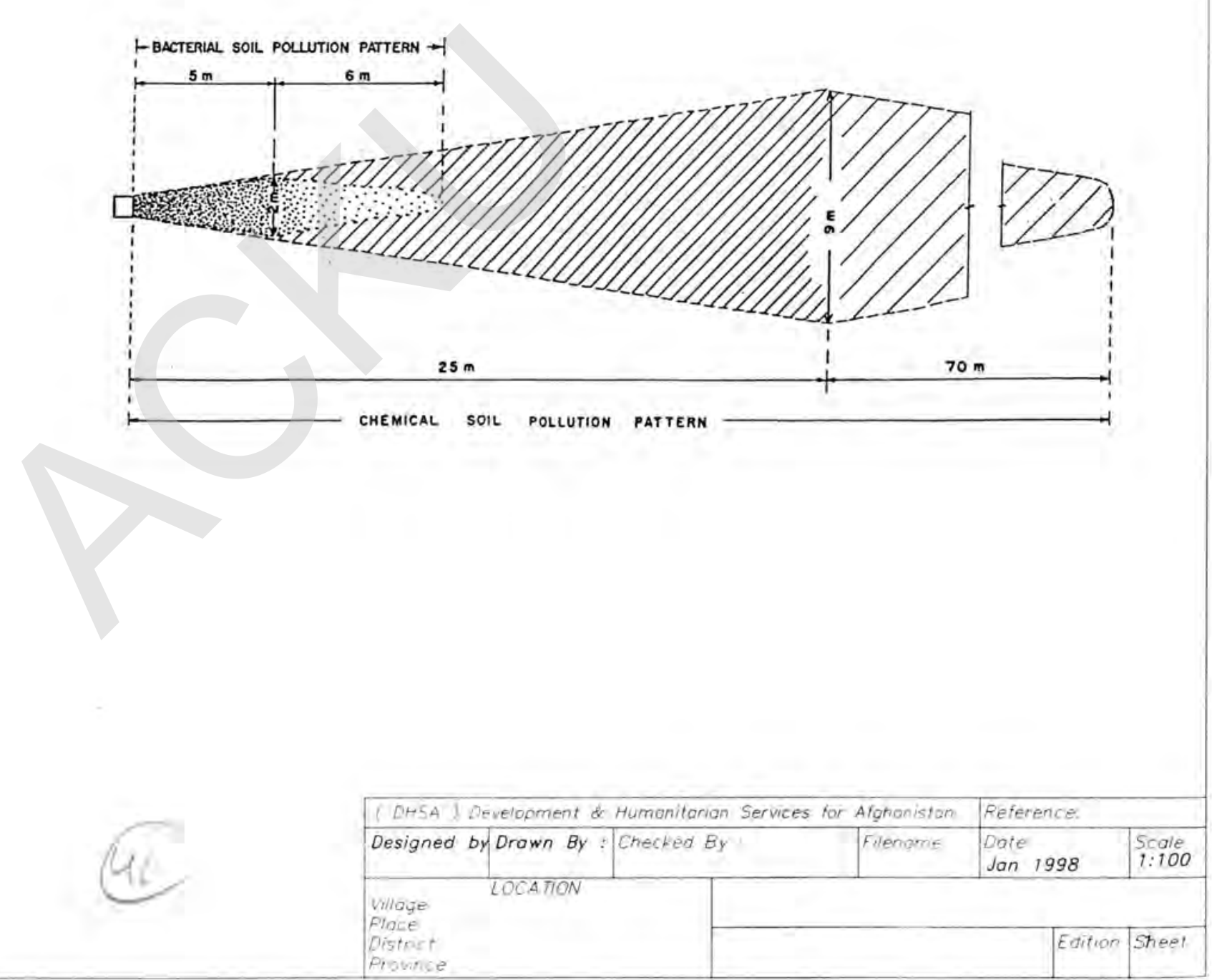




\section{Surface Latrine Construction}

Cost of one latrine in Balkh province

\begin{tabular}{|c|c|c|c|c|c|}
\hline Qescription & Enitit & Quantity & Git cost & Total Rs: & Totaiss \\
\hline \multicolumn{6}{|c|}{1 - Expendable Material } \\
\hline Cement & bag & 3 & 325 & 975 & 22,16 \\
\hline Sand \& Gravel & $\mathrm{m}^{3}$ & 0,334 & 707 & 236 & 5,37 \\
\hline Stone & $\mathrm{m}^{3}$ & 3 & 707 & 2121 & 48,20 \\
\hline Soil & $m^{3}$ & 1,2 & 290 & 348 & 7,91 \\
\hline Steel bar & $\mathrm{kg}$ & 6,52 & 50 & 326 & 7,41 \\
\hline Bending Wire & $\mathrm{kg}$ & 0,5 & 50 & 25 & 0,57 \\
\hline Woden Bar $2 \mathrm{~m}$ & nos & 9 & 144 & 1296 & 29,45 \\
\hline Woden Plank & nos & 5 & 150 & 750 & 17,04 \\
\hline Chute & $\mathrm{m}$ & 3 & 37 & 111 & 2,52 \\
\hline CPVPipe + Screen Wire & $m$ & 6 & 115 & 690 & 15,68 \\
\hline Nail & $\mathrm{kg}$ & 0,5 & 50 & 25 & 0,57 \\
\hline Transport cost & Lumpsum & & & 1292 & 29,36 \\
\hline \multicolumn{4}{|l|}{ Sub-total } & 8195 & 186,23 \\
\hline
\end{tabular}

\section{2 - Non-expendable Material}

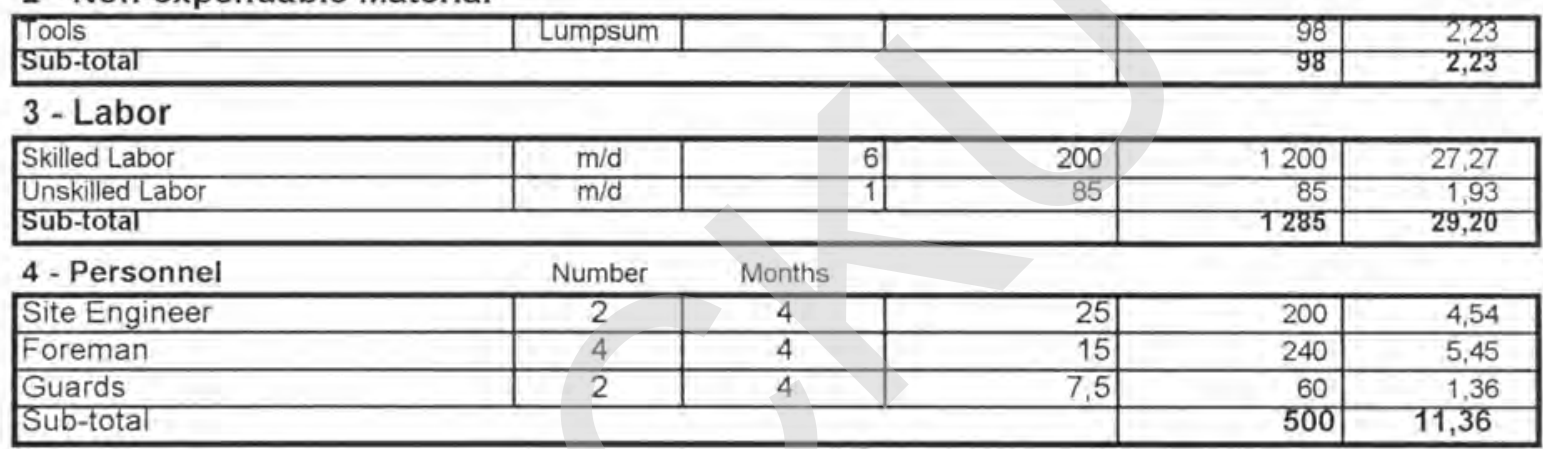




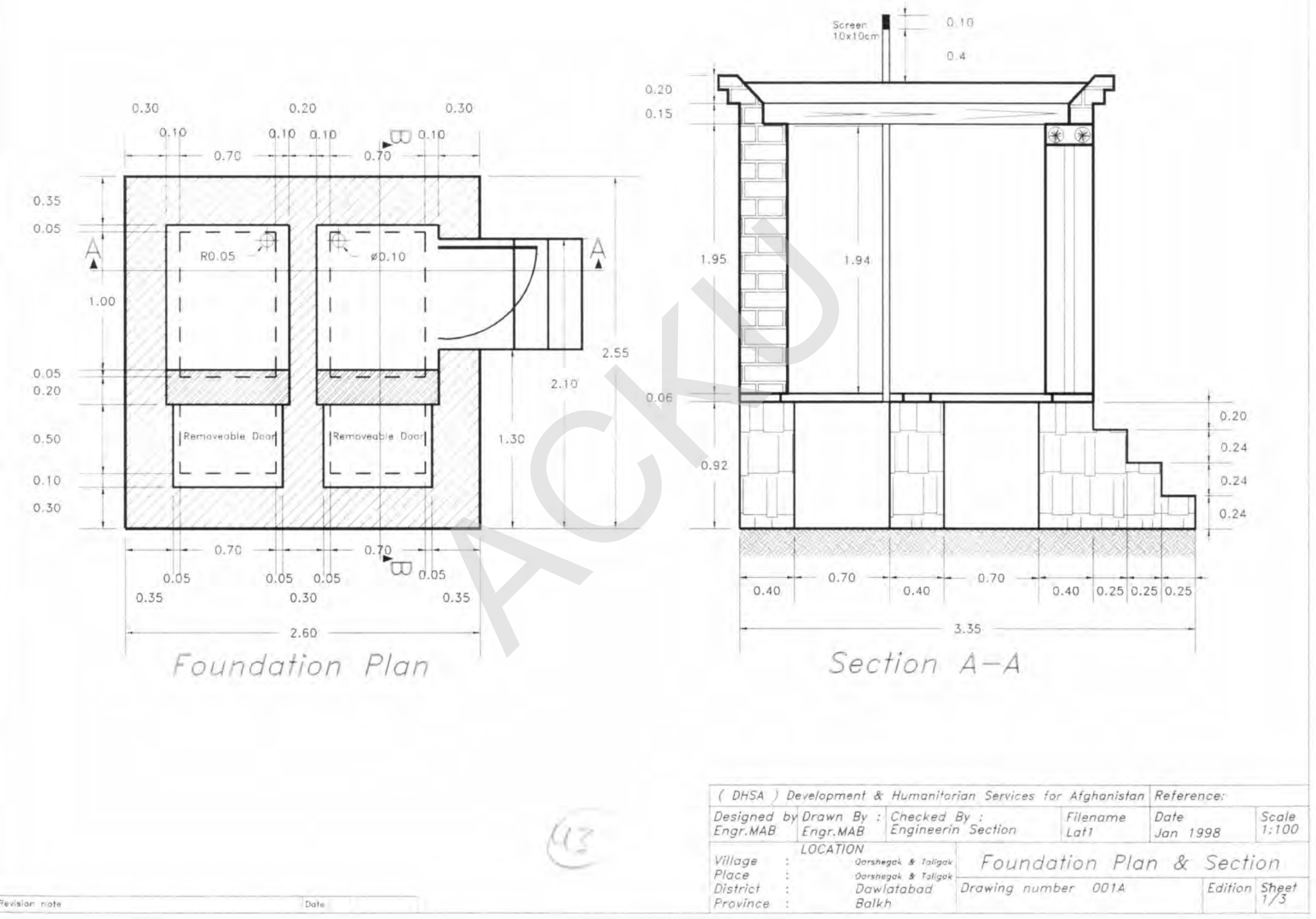


2 \# R.C.C. Slab

.90
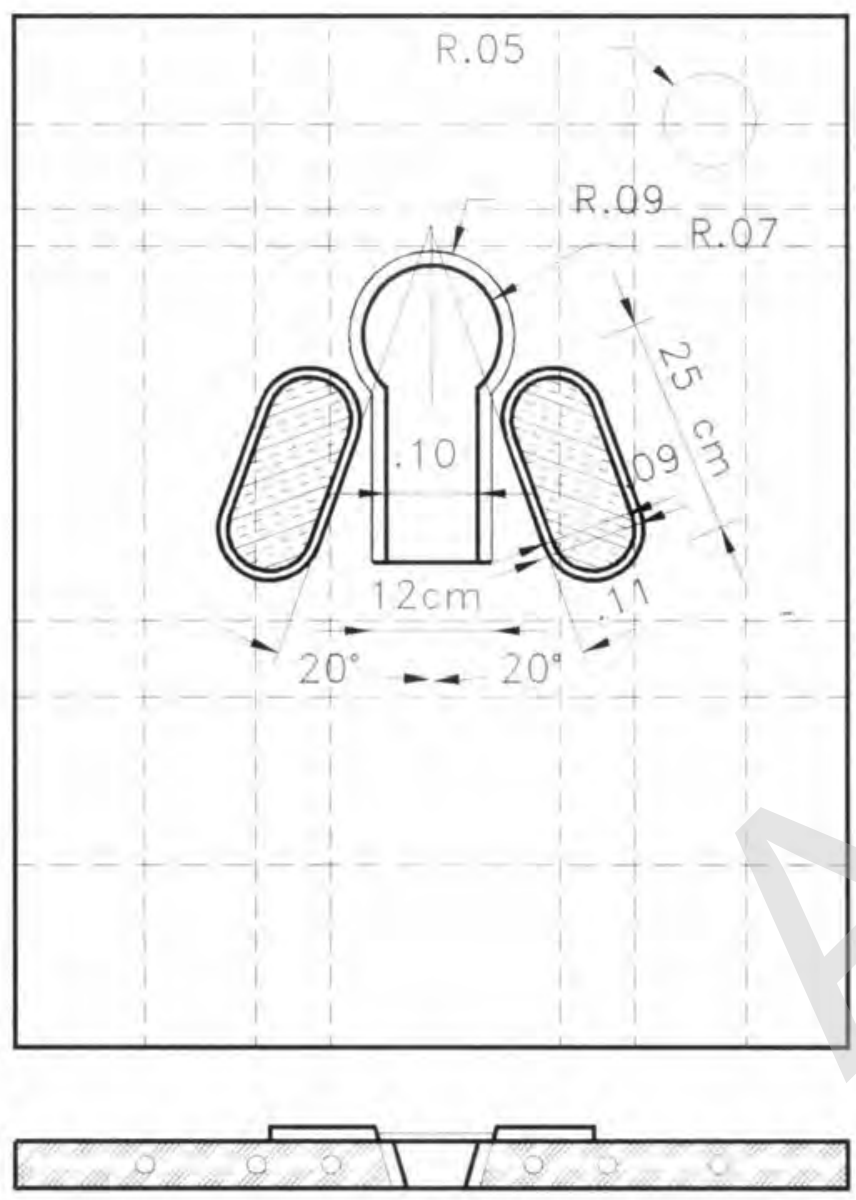

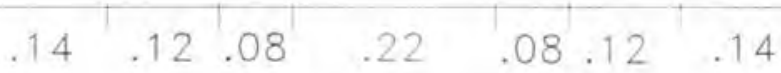

Beam

4 \# dig of 90

at length of $90 \mathrm{~cm}$
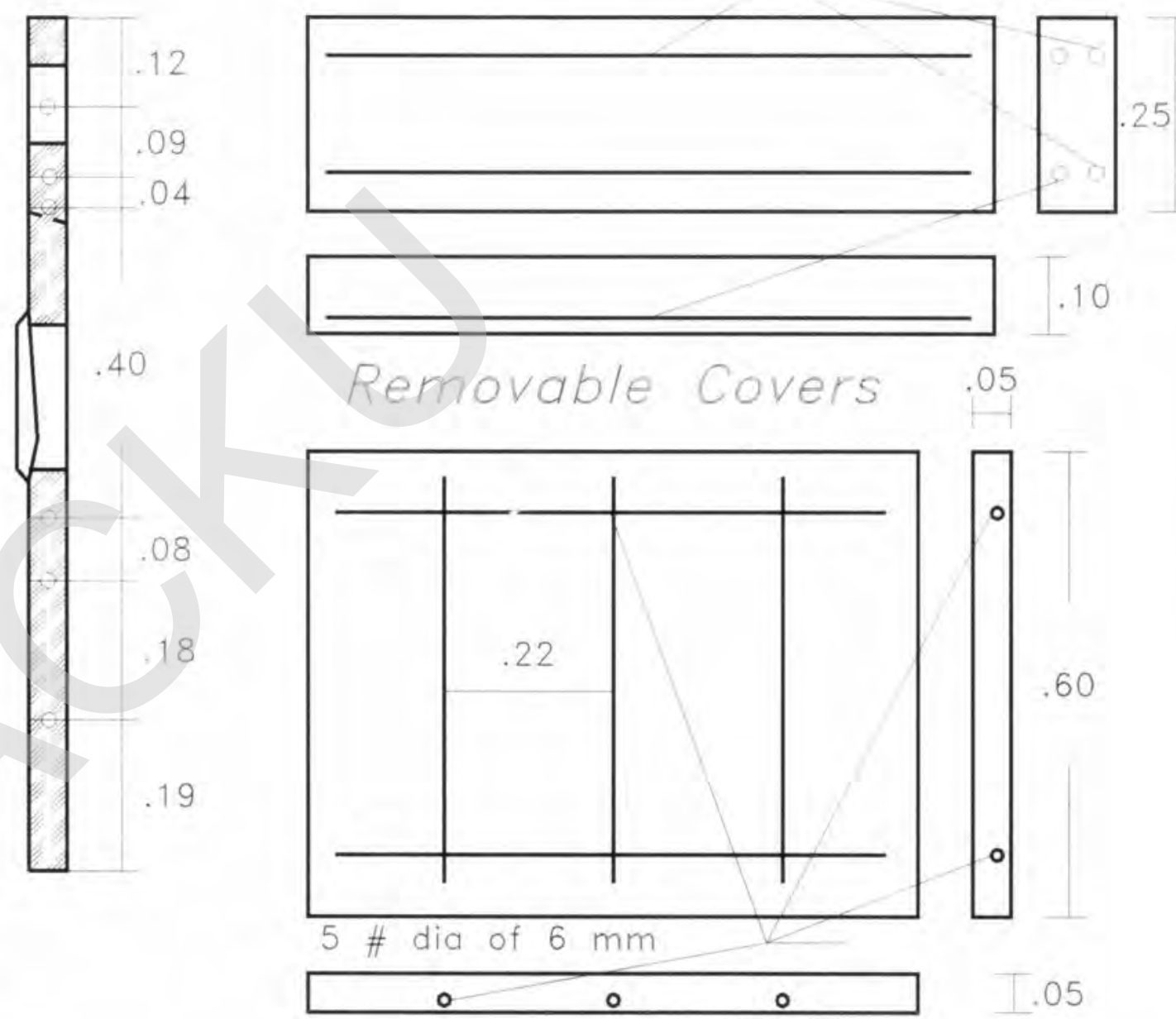

.80

( DHSA ) Development \& Humanitarian Services for Afghanistan Reference:EDRASC \begin{tabular}{ll|l|l|l} 
Designed by Drawn By : $\begin{array}{l}\text { Checked By: } \\
\text { Engineerin Section }\end{array}$ Filename & $\begin{array}{l}\text { Date } \\
\text { Engr.MAB }\end{array}$ & $\begin{array}{l}\text { Scale } \\
\text { Jan } 1998\end{array}$ \\
$1: 100$
\end{tabular} Engr.MAB Engr.MAB Engineerin Section

Darshogoh \& taligok Section \& Schedule of Bars \begin{tabular}{l|l} 
Dawlatabod & Drawing number \\
Dath &
\end{tabular} Balkh 
COMMUNITY BUILDINGS

Province: Balkh

Type of project: Primary School Building
Village: Baba Seddiq

District: Khulm

\begin{tabular}{|c|c|c|c|c|}
\hline No. & ITEMS & Unit & Number & Period \\
\hline & \multicolumn{4}{|c|}{ 1-Expendable Material } \\
\hline 1 & Stone & $\mathrm{m} 3$ & 123 & \\
\hline 2 & Cement & bag & 211 & \\
\hline 3 & Sand Gravel & $\mathrm{m} 3$ & 145 & \\
\hline 4 & Burned Brick & nos. & 164212 & \\
\hline 5 & Soil & $\mathrm{m} 3$ & 145 & \\
\hline 6 & Lime & $\mathrm{kg}$ & 7617 & \\
\hline 7 & Gypsum & $\mathrm{kg}$ & 406 & \\
\hline 8 & Marble Clod & $\mathrm{kg}$ & 262 & \\
\hline 9 & Wooden bar $5 \mathrm{~m}$ & nos. & 146 & \\
\hline 10 & Wooden bar $4 \mathrm{~m}$ & nos. & 114 & \\
\hline 11 & Wooden bar $2 \mathrm{~m}$ & nos. & 36 & \\
\hline 12 & Wooden board & nos. & 1200 & \\
\hline 13 & Straw & $\mathrm{kg}$ & 2090 & \\
\hline 14 & Reed & bundle & 100 & \\
\hline 15 & Glue & $\mathrm{kg}$ & 28 & \\
\hline 16 & Oil paint & $\mathrm{kg}$ & 38 & \\
\hline 17 & Powder paint & $\mathrm{kg}$ & 32 & \\
\hline 18 & Nail & $\mathrm{kg}$ & 30 & \\
\hline 19 & Glass 3mm & $\mathrm{m} 2$ & 56 & \\
\hline 20 & Blot lock & nos. & 25 & \\
\hline 21 & Hinges $3^{\prime \prime}$ & pair & 30 & \\
\hline 22 & Hinges 4" & pair & 30 & \\
\hline 23 & Window handle & pair & 42 & \\
\hline 24 & Plastic & $\mathrm{m} 2$ & 411 & \\
\hline 25 & Wire screen & $\mathrm{m}$ & 52 & 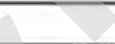 \\
\hline 26 & Chute & $\mathrm{m}$ & 24 & \\
\hline 27 & Putty & $\mathrm{kg}$ & 3,19 & \\
\hline 28 & Door / window & $\mathrm{m} 2$ & 19 & \\
\hline 29 & Door & $\mathrm{m} 2$ & 24 & \\
\hline 30 & window & $\mathrm{m} 2$ & 50 & \\
\hline 31 & Transport & & + & \\
\hline
\end{tabular}

\begin{tabular}{|l|l|l}
\hline Unit cost & Rs. & US\$ \\
\hline
\end{tabular}

\begin{tabular}{|c|c|c|}
\hline 450 & 55350 & 1257,78 \\
\hline 325 & 68575 & 1558,31 \\
\hline 450 & 65250 & 1482,75 \\
\hline 1,6 & 262739 & 5970,53 \\
\hline 290 & 42050 & 955,55 \\
\hline 3 & 22851 & 519,27 \\
\hline 22 & 8932 & 202,97 \\
\hline 18 & 4716 & 107.17 \\
\hline 468 & 68328 & 1552,70 \\
\hline 423 & 48222 & 1095,81 \\
\hline 144 & 5184 & 117,80 \\
\hline 150 & 180000 & 4090,35 \\
\hline 2,9 & 6061 & 137,73 \\
\hline 4 & 400 & 9,09 \\
\hline 50 & 1400 & 31,81 \\
\hline 135 & 5130 & 116,58 \\
\hline 80 & 2560 & 58,17 \\
\hline 50 & 1500 & 34,09 \\
\hline 240 & 13440 & 305,41 \\
\hline 450 & 11250 & 255,65 \\
\hline 35 & 1050 & 23,86 \\
\hline 35 & 1050 & 23,86 \\
\hline 80 & 3360 & 76,35 \\
\hline 12 & 4932 & 112,08 \\
\hline 50 & 2600 & 59,08 \\
\hline 37 & 888 & 20,18 \\
\hline 30 & 96 & 2,17 \\
\hline 850 & 16150 & 367,00 \\
\hline 850 & 20400 & 463,57 \\
\hline \multirow[t]{3}{*}{750} & 37500 & 852,16 \\
\hline & 13190 & 299,73 \\
\hline & 975154 & 22159,57 \\
\hline
\end{tabular}

Sub total

\section{2 - Non-expendable Material}

\begin{tabular}{|l|l|l}
\hline 32 & Buckets & natky \\
\hline 33 & Tatky & n \\
\hline 34 & Barrel & n \\
\hline 35 & Smoother & n \\
\hline 36 & Hammer & n \\
\hline 37 & Hand Tamper & n \\
\hline 38 & Shovel & n \\
\hline 39 & Pick Axe & n \\
\hline 40 & Wheel barrow & \\
\hline \multicolumn{2}{|c|}{ Sub total } \\
\hline \multicolumn{2}{|c|}{ 3-Labor }
\end{tabular}

\begin{tabular}{|c|c|}
\hline nos. & 5 \\
\hline nos. & 5 \\
\hline nos. & 3 \\
\hline nos. & 5 \\
\hline nos. & 5 \\
\hline nos. & 2 \\
\hline nos. & 1 \\
\hline nos. & 1 \\
\hline nos. & 4 \\
\hline
\end{tabular}

\begin{tabular}{|l|l|}
\hline 5 \\
\hline 5 \\
\hline 3 \\
\hline 5 \\
\hline 5 \\
\hline 2 \\
\hline 10 \\
\hline 10 \\
\hline 4 \\
\hline
\end{tabular}

\begin{tabular}{|l|l|}
\hline \\
\hline \\
\hline \\
\hline
\end{tabular}

\begin{tabular}{|r|r|}
\hline 70 \\
\hline 45 \\
\hline 450 \\
40 \\
\hline 30 \\
\hline 160 \\
\hline 80 \\
\hline 120 \\
\hline 1450 \\
\hline
\end{tabular}

$70 \quad 350$

$45-225$

225

$40 \quad 200$

$30 \quad 150$

$160 \quad 320$

$80 \quad 800$

$120 \quad 1200$

$1450 \quad 5800$

10395

\begin{tabular}{|l|l|l|l|r|r|r|r|}
\hline 41 & Skilled labor & $\mathrm{m} / \mathrm{d}$ & 545 & & 200 & 109000 & 2476,93 \\
\hline 42 & Unskilled labor & $\mathrm{m} / \mathrm{d}$ & 1084 & & 85 & 92140 & 2093,81 \\
\hline
\end{tabular}

\section{4- Personal}

\begin{tabular}{|l|l|}
\hline 43 & Site Supervisor \\
\hline 44 & Foreman \\
\hline 45 & Guard \\
\hline
\end{tabular}

Sub total

\begin{tabular}{|r|r|}
\hline 25000 & 568,10 \\
\hline 15000 & 340,86 \\
\hline 15000 & 340,86 \\
\hline 55000 & 1249,83 \\
\hline 1241689 & 28216,35 \\
\hline
\end{tabular}




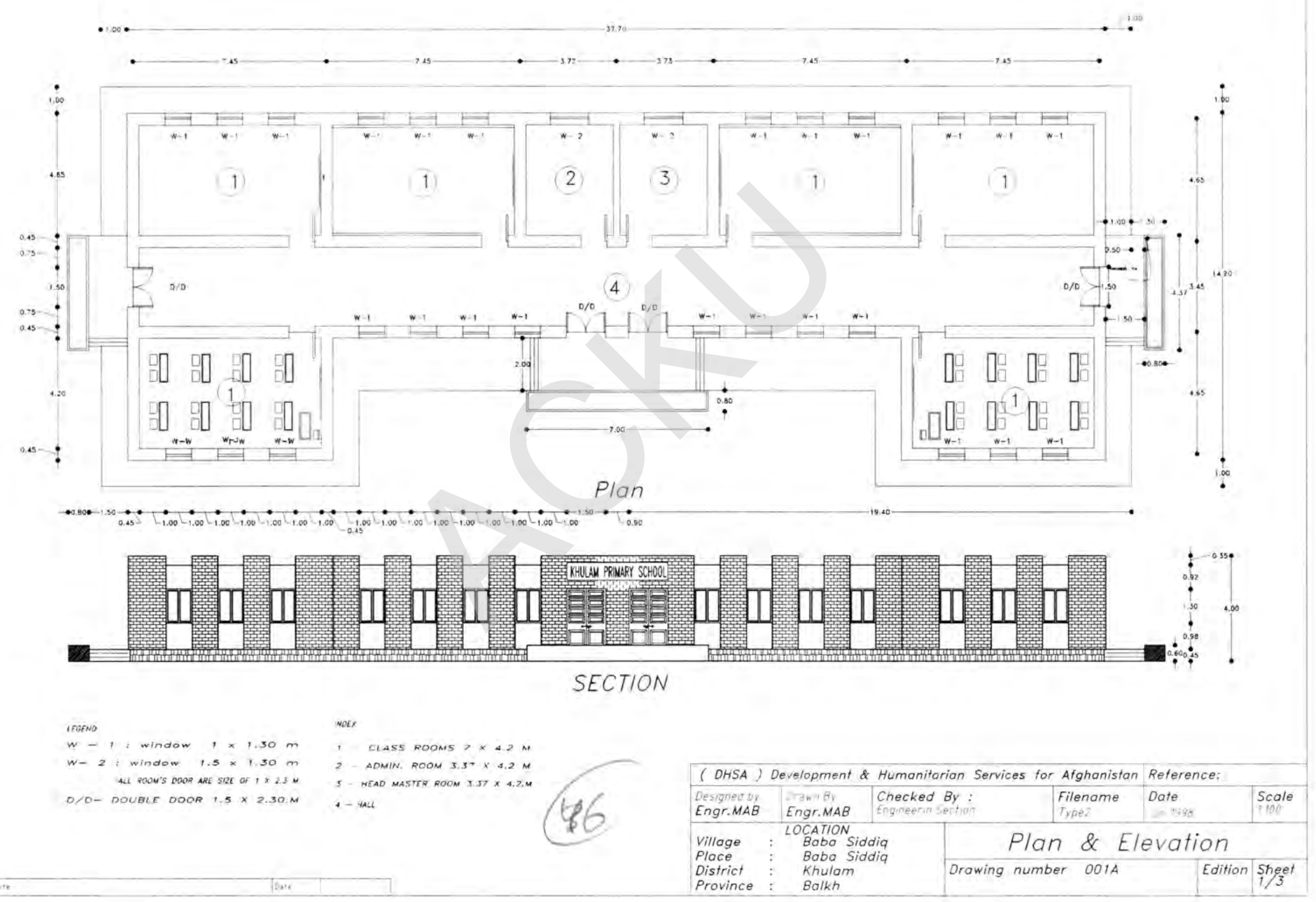


COMMUNITY BUILDINGS

'illage:Yangi Areq

listrict: Khulm

\begin{tabular}{l|l}
\hline istrict: Khulm \\
\hline No. & \multicolumn{1}{|c}{ ITEMS } \\
\hline \multicolumn{2}{|c}{1 -Expendable Material } \\
\hline 1 & Stone \\
\hline 2 & Cement \\
\hline 3 & Sand Gravel \\
\hline 4 & Burned Brick \\
\hline 5 & Soil \\
\hline 6 & Lime \\
\hline 7 & Gypsum \\
\hline 8 & Marble Clod \\
\hline 9 & Wooden bar $5 \mathrm{~m}$ \\
\hline 10 & Wooden bar $4 \mathrm{~m}$ \\
\hline 11 & Wooden bar $2 \mathrm{~m}$ \\
\hline 12 & Wooden board \\
\hline 13 & Straw \\
\hline 14 & Reed \\
\hline 15 & Glue \\
\hline 16 & Oil paint \\
\hline 17 & Powder paint \\
\hline 18 & Nail \\
\hline 19 & Glass 3mm \\
\hline 20 & Blot lock \\
\hline 21 & Hinges $3 "$ \\
\hline 22 & Hinges 4" \\
\hline 23 & Window handle \\
\hline 24 & Plastic \\
\hline 25 & Wire screen \\
\hline 26 & Chute \\
\hline 27 & Putty \\
\hline 28 & Door /window \\
\hline 29 & Door \\
\hline 30 & window \\
\hline 31 & Transport \\
\hline & Su tota \\
\hline
\end{tabular}

Province: Balkh

Type of project: Primary School Building

\begin{tabular}{|c|c|c|c|c|c|}
\hline Unit & Number & Period & Unit cost & Rs. & US\$ \\
\hline $\mathrm{m} 3$ & 123 & & 450 & 55350 & 1257,78 \\
\hline bag & 211 & & 325 & 68575 & 1558,31 \\
\hline $\mathrm{m} 3$ & 145 & & 450 & 65250 & 1482,75 \\
\hline nos. & 164212 & & 1,6 & 262739 & 5970,53 \\
\hline $\mathrm{m3}$ & 145 & & 290 & 42050 & 955,55 \\
\hline $\mathrm{kg}$ & 7617 & & 3 & 22851 & 519,27 \\
\hline $\mathrm{kg}$ & 406 & & 22 & 8932 & 202,97 \\
\hline $\mathrm{kg}$ & 262 & & 18 & 4716 & 107,17 \\
\hline nos. & 146 & & 468 & 68328 & 1552,70 \\
\hline nos. & 114 & & 423 & 48222 & 1095,81 \\
\hline nos. & 36 & & 144 & 5184 & 117,80 \\
\hline nos. & 1200 & & 150 & 180000 & 4090,35 \\
\hline $\mathrm{kg}$ & 2090 & & 2,9 & 6061 & 137,73 \\
\hline bundle & 100 & & 4 & 400 & 9,09 \\
\hline $\mathrm{kg}$ & 28 & & 50 & 1400 & 31,81 \\
\hline $\mathrm{kg}$ & 38 & & 135 & 5130 & 116,58 \\
\hline $\mathrm{kg}$ & 32 & & 80 & 2560 & 58,17 \\
\hline $\mathrm{kg}$ & 30 & & 50 & 1500 & 34,09 \\
\hline $\mathrm{m} 2$ & 56 & & 240 & 13440 & 305,41 \\
\hline nos. & 25 & & 450 & 11250 & 255,65 \\
\hline pair & 30 & & 35 & 1050 & 23,86 \\
\hline pair & 30 & & 35 & 1050 & 23,86 \\
\hline pair & 42 & $\Delta$ & 80 & 3360 & 76,35 \\
\hline $\mathrm{m} 2$ & 411 & & 12 & 4932 & 112,08 \\
\hline $\mathrm{m}$ & 52 & 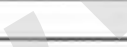 & 50 & 2600 & 59,08 \\
\hline $\mathrm{m}$ & 24 & & 37 & 888 & 20,18 \\
\hline $\mathrm{kg}$ & 3,19 & & 30 & 96 & 2,17 \\
\hline $\mathrm{m} 2$ & 19 & $Z$ & 850 & 16150 & 367,00 \\
\hline $\mathrm{m} 2$ & 24 & & 850 & 20400 & 463,57 \\
\hline \multirow[t]{2}{*}{$\mathrm{m} 2$} & 50 & & 750 & 37500 & 852,16 \\
\hline & 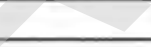 & & & 13190 & 299,73 \\
\hline & & & & 975154 & 22159,57 \\
\hline
\end{tabular}

2 - Non-expendable Material

\begin{tabular}{|c|c|c|c|c|c|c|c|}
\hline 32 & Buckets & nos. & 5 & & 70 & 350 & 7,95 \\
\hline 33 & Tatky & nos. & 5 & & 45 & 225 & 5,11 \\
\hline 34 & Barrel & nos. & 3 & & 450 & 1350 & 30,68 \\
\hline 35 & Smoother & nos. & 5 & & 40 & 200 & 4,54 \\
\hline 36 & Hammer & nos. & 5 & & 30 & 150 & 3,41 \\
\hline 37 & Hand Tamper & nos. & 2 & & 160 & 320 & 7,27 \\
\hline 38 & Shovel & nos. & 10 & & 80 & 800 & 18,18 \\
\hline 39 & Pick Axe & nos. & 10 & & 120 & 1200 & 27,27 \\
\hline 40 & Wheel barrow & nos. & 4 & & 1450 & 5800 & 131,80 \\
\hline \multicolumn{6}{|c|}{ Sub total } & 10395 & 236,22 \\
\hline \multicolumn{8}{|c|}{3 -Labor } \\
\hline 41 & Skilled labor & $\mathrm{m} / \mathrm{d}$ & 545 & & 200 & 109000 & 2476,93 \\
\hline 42 & Unskilled labor & $\mathrm{m} / \mathrm{d}$ & 1084 & & 85 & 92140 & 2093,81 \\
\hline \multicolumn{6}{|c|}{ Sub total } & 201140 & 4570,74 \\
\hline \multicolumn{8}{|c|}{ 4-Personal } \\
\hline 43 & Site Supervisor & & 1 & 5 & 5000 & 25000 & 568,10 \\
\hline 44 & Foreman & & 1 & 5 & 3000 & 15000 & 340,86 \\
\hline 45 & Guard & & 2 & 5 & 1500 & 15000 & 340,86 \\
\hline \multicolumn{6}{|c|}{ Sub total } & 55000 & 1249,83 \\
\hline \multicolumn{6}{|c|}{ TOTAL } & 1241689 & 28216,35 \\
\hline
\end{tabular}




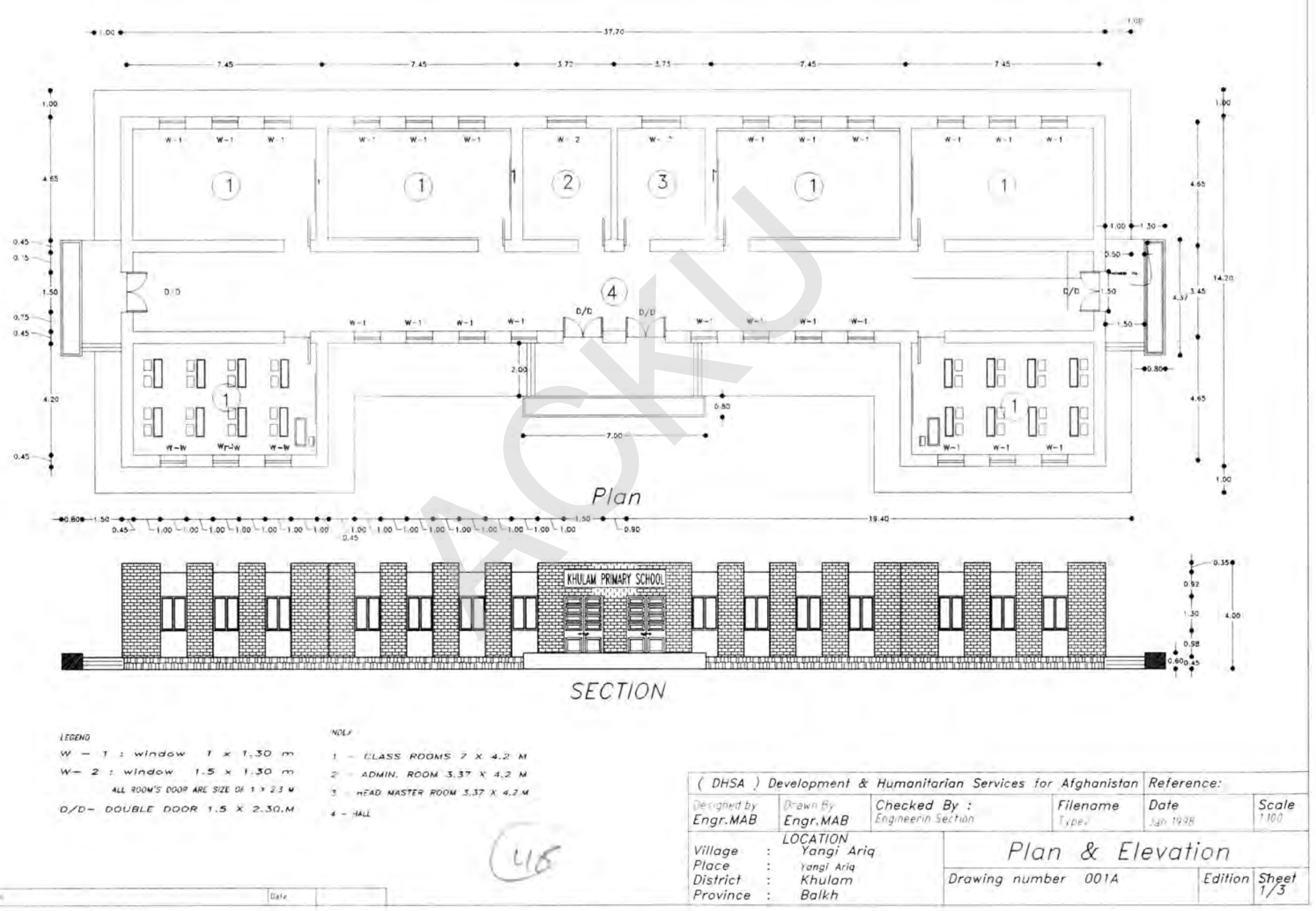




\section{ROAD - BRIDGES - CULVERTS}

Type of Project: Small Bridge $(3 \times 6,5 \times 2,5) \#-1$

District: Balkh

Location: Qariae Bahawuddin

Province: Balkh

\begin{tabular}{|c|c|c|c|c|c|c|}
\hline No. & \begin{tabular}{|c|} 
ITEMS \\
\end{tabular} & Unit & Number & Unit cost & Rs. & US\$ \\
\hline \multicolumn{7}{|c|}{ 1-Expendable Material } \\
\hline 1 & Stone & m3 & 80,25 & 707 & 56737 & 1289,30 \\
\hline 2 & Cement & bag & 187 & 325 & 60775 & 1381,06 \\
\hline 3 & Sand \& Gravel & $\mathrm{m} 3$ & 40 & 707 & 28280 & 642,64 \\
\hline 4 & Sand & $\mathrm{m} 3$ & 5,2 & 707 & 3676 & 83,54 \\
\hline 5 & Wooden Beam 3m & nos & 88 & 382 & 33616 & 763,90 \\
\hline 6 & Wooden Plank $(2.5 \mathrm{~cm})$ & nos & 90 & 150 & 13500 & 306,78 \\
\hline 7 & Steel Bar & $\mathrm{kg}$ & 883 & 50 & 44150 & 1003,27 \\
\hline 8 & Bending Wire & $\mathrm{kg}$ & 6 & 100 & 600 & 13,63 \\
\hline 9 & Nail & $\mathrm{kg}$ & 5 & 50 & 250 & 5,68 \\
\hline 10 & Transport cost & Lumpsum & & & 11764 & 267,33 \\
\hline \multicolumn{4}{|c|}{ Sub-total } & & 253348 & 5757,13 \\
\hline \multicolumn{7}{|c|}{2 - Non-expendable Material } \\
\hline 11 & Tools & Lumpsum & & & 3281 & 74,56 \\
\hline \multicolumn{5}{|c|}{ Sub-total } & 3281 & 74,56 \\
\hline \multicolumn{7}{|c|}{3 - Labor } \\
\hline 12 & Skilled Labor & $\mathrm{m} / \mathrm{d}$ & 95 & 200 & 19000 & 431,76 \\
\hline 13 & Unskilled Labor & $\mathrm{m} / \mathrm{d}$ & 187 & 85 & 15895 & 361,20 \\
\hline \multicolumn{3}{|c|}{ Sub-total } & & & 34895 & 792,96 \\
\hline & & TOTAL & & & 291524,15 & 6624,65 \\
\hline
\end{tabular}




\section{ROAD - BRIDGES - CULVERTS}

Type of Project: Small Bridge $(3 \times 6,5 \times 2,5) \#-2$ Location: Qariae Bahawuddin

District: Balkh

Province: Balkh

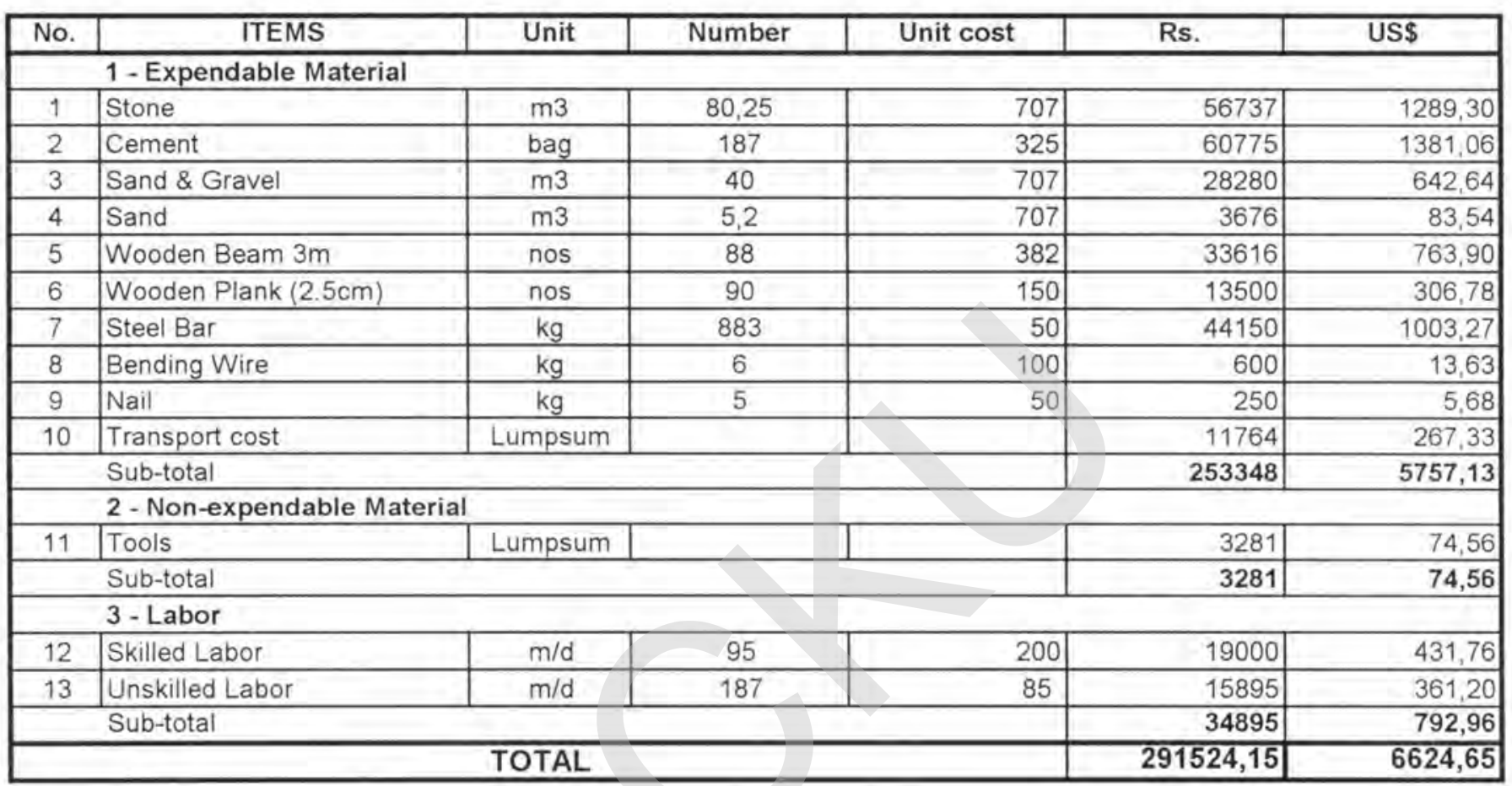




\section{ROAD - BRIDGES - CULVERTS}

Type of Project: Small Bridge $(3 \times 6,5 \times 2,5) \#-3$

Location: Joy Anboh, Qariae Bahawuddin
District: Balkh

Province: Balkh

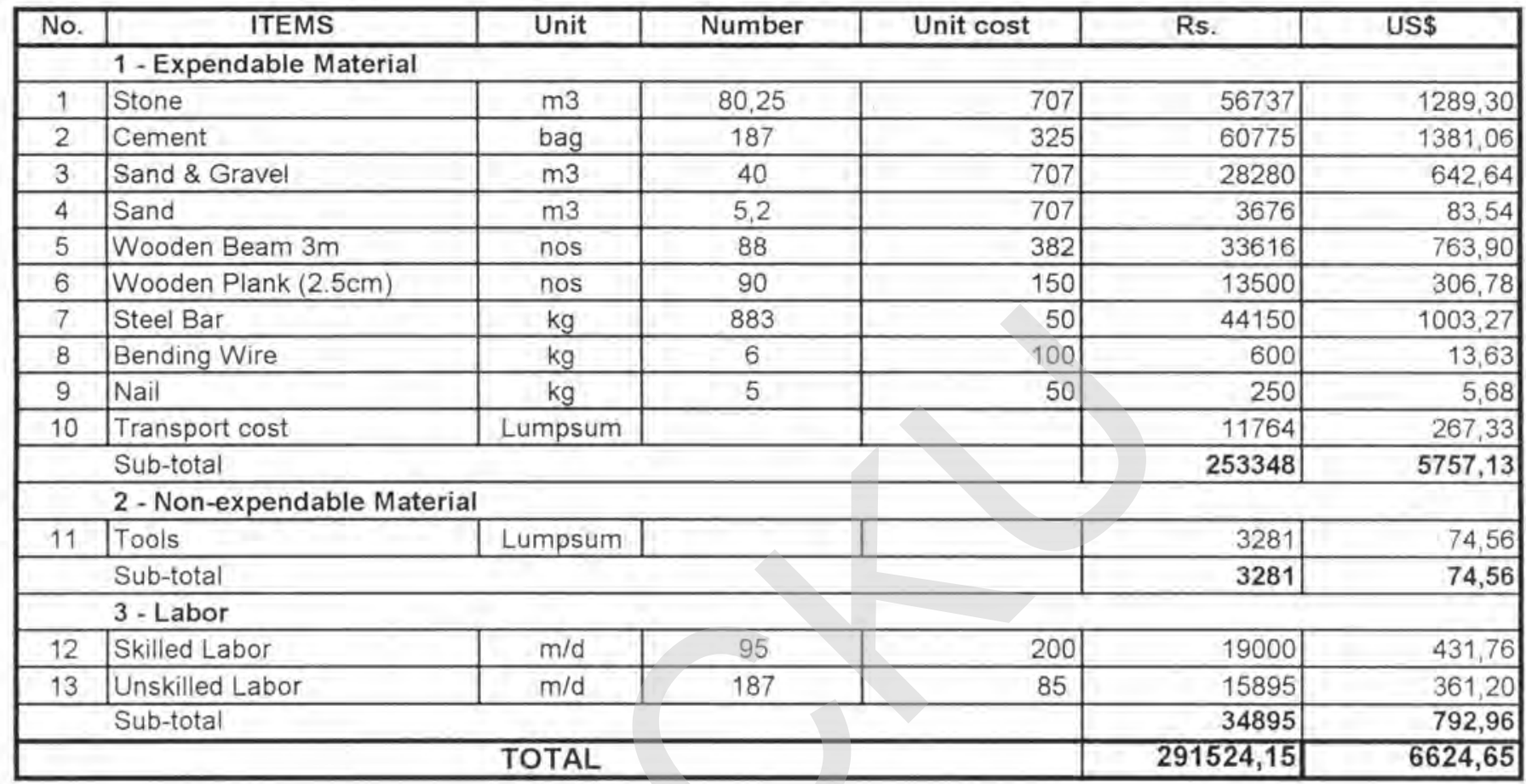




\section{ROAD - BRIDGES - CULVERTS}

Type of Project: Small Bridge $(3 \times 6,5 \times 2,5) \#-4$ Location: Kole Anboh

District: Balkh

Province: Balkh

\begin{tabular}{|c|c|c|c|c|c|c|}
\hline No. & ITEMS & Unit & Number & Unit cost & Rs. & US\$ \\
\hline \multicolumn{7}{|c|}{1 - Expendable Material } \\
\hline 1 & Stone & m3 & 80,25 & 707 & 56737 & 1289,30 \\
\hline 2 & Cement & bag & 187 & 325 & 60775 & 1381,06 \\
\hline 3 & Sand \& Gravel & $\mathrm{m} 3$ & 40 & 707 & 28280 & 642,64 \\
\hline 4 & Sand & $\mathrm{m} 3$ & 5,2 & 707 & 3676 & 83,54 \\
\hline 5 & Wooden Beam 3m & nos & 88 & 382 & 33616 & 763,90 \\
\hline 6 & Wooden Plank $(2.5 \mathrm{~cm})$ & nos & 90 & 150 & 13500 & 306,78 \\
\hline 7 & Steel Bar & $\mathrm{kg}$ & 883 & 50 & 44150 & 1003,27 \\
\hline 8 & Bending Wire & $\mathrm{kg}$ & 6 & 100 & 600 & 13,63 \\
\hline 9 & Nail & $\mathrm{kg}$ & 5 & 50 & 250 & 5,68 \\
\hline 10 & Transport cost & Lumpsum & & & 11764 & 267,33 \\
\hline \multicolumn{4}{|c|}{ Sub-total } & & 253348 & 5757,13 \\
\hline \multicolumn{7}{|c|}{2 - Non-expendable Material } \\
\hline 11 & Tools & Lumpsum & & 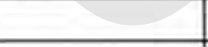 & 3281 & 74,56 \\
\hline \multicolumn{5}{|c|}{ Sub-total } & 3281 & 74,56 \\
\hline \multicolumn{7}{|c|}{3 - Labor } \\
\hline 12 & Skilled Labor & $\mathrm{m} / \mathrm{d}$ & 95 & 200 & 19000 & 431,76 \\
\hline 13 & Unskilled Labor & $\mathrm{m} / \mathrm{d}$ & 187 & 85 & 15895 & 361,20 \\
\hline \multicolumn{5}{|c|}{ Sub-total } & 34895 & 792,96 \\
\hline & & TOTAL & & & 291524,15 & 6624,65 \\
\hline
\end{tabular}




\section{ROAD - BRIDGES - CULVERTS}

Type of Project: Small Bridge $(3 \times 6,5 \times 2,5) \#-5$

District: Balkh

Location: Kole Anboh

Province: Balkh

\begin{tabular}{|c|c|c|c|c|c|c|}
\hline No. & ITEMS & Unit & Number & Unit cost & Rs. & US\$ \\
\hline \multicolumn{7}{|c|}{ 1-Expendable Material } \\
\hline 1 & Stone & m3 & 80,25 & 707 & 56737 & 1289,30 \\
\hline 2 & Cement & bag & 187 & 325 & 60775 & 1381,06 \\
\hline 3 & Sand \& Gravel & $\mathrm{m} 3$ & 40 & 707 & 28280 & 642,64 \\
\hline 4 & Sand & $\mathrm{m} 3$ & 5,2 & 707 & 3676 & 83,54 \\
\hline 5 & Wooden Beam 3m & nos & 88 & 382 & 33616 & 763,90 \\
\hline 6 & Wooden Plank $(2.5 \mathrm{~cm})$ & nos & 90 & 150 & 13500 & 306,78 \\
\hline 7 & Steel Bar & $\mathrm{kg}$ & 883 & 50 & 44150 & 1003,27 \\
\hline 8 & Bending Wire & $\mathrm{kg}$ & 6 & 100 & 600 & 13,63 \\
\hline 9 & Nail & $\mathrm{kg}$ & 5 & 50 & 250 & 5,68 \\
\hline 10 & Transport cost & Lumpsum & & & 11764 & 267,33 \\
\hline \multicolumn{4}{|c|}{ Sub-total } & & 253348 & 5757,13 \\
\hline \multicolumn{7}{|c|}{2 - Non-expendable Material } \\
\hline 11 & Tools & Lumpsum & & & 3281 & 74,56 \\
\hline \multicolumn{5}{|c|}{ Sub-total } & 3281 & 74,56 \\
\hline \multicolumn{7}{|c|}{3 -Labor } \\
\hline 12 & Skilled Labor & $\mathrm{m} / \mathrm{d}$ & 95 & 200 & 19000 & 431,76 \\
\hline 13 & Unskilled Labor & $\mathrm{m} / \mathrm{d}$ & 187 & 85 & 15895 & 361,20 \\
\hline \multicolumn{3}{|c|}{ Sub-total } & & & 34895 & 792,96 \\
\hline & & TOTAL & & & 291524,15 & 6624,65 \\
\hline
\end{tabular}




\section{ROAD - BRIDGES - CULVERTS}

Type of Project: Small Bridge $(3 \times 6,5 \times 2,5) \#-7$

District: Balkh

Location: Kole Anboh (Nahre Asfahan)

Province: Balkh

\begin{tabular}{|c|c|c|c|c|c|c|}
\hline No. & ITEMS & Unit & Number & Unit cost & Rs. & US\$ \\
\hline \multicolumn{7}{|c|}{ 1-Expendable Material } \\
\hline 1 & Stone & $\mathrm{m} 3$ & 80,25 & 707 & 56737 & 1289,30 \\
\hline 2 & Cement & bag & 187 & 325 & 60775 & 1381,06 \\
\hline 3 & Sand \& Gravel & $\mathrm{m} 3$ & 40 & 707 & 28280 & 642,64 \\
\hline 4 & Sand & $\mathrm{m} 3$ & 5,2 & 707 & 3676 & 83,54 \\
\hline 5 & Wooden Beam 3m & nos & 88 & 382 & 33616 & 763,90 \\
\hline 6 & Wooden Plank $(2.5 \mathrm{~cm})$ & nos & 90 & 150 & 13500 & 306,78 \\
\hline 7 & Steel Bar & $\mathrm{kg}$ & 883 & 50 & 44150 & 1003,27 \\
\hline 8 & Bending Wire & $\mathrm{kg}$ & 6 & 100 & 600 & 13,63 \\
\hline 9 & Nail & $\mathrm{kg}$ & 5 & 50 & 250 & 5,68 \\
\hline 10 & Transport cost & Lumpsum & & & 11764 & 267,33 \\
\hline \multicolumn{4}{|c|}{ Sub-total } & & 253348 & 5757,13 \\
\hline \multicolumn{7}{|c|}{2 - Non-expendable Material } \\
\hline 11 & Tools & Lumpsum & & & 3281 & 74,56 \\
\hline \multicolumn{5}{|c|}{ Sub-total } & 3281 & 74,56 \\
\hline \multicolumn{7}{|c|}{3 - Labor } \\
\hline 12 & Skilled Labor & $\mathrm{m} / \mathrm{d}$ & 95 & 200 & 19000 & 431,76 \\
\hline 13 & Unskilled Labor & $\mathrm{m} / \mathrm{d}$ & 187 & 85 & 15895 & 361,20 \\
\hline \multirow{2}{*}{\multicolumn{2}{|c|}{ Sub-total }} & & & & 34895 & 792,96 \\
\hline & & TOTAL & & & 291524,15 & 6624,65 \\
\hline
\end{tabular}




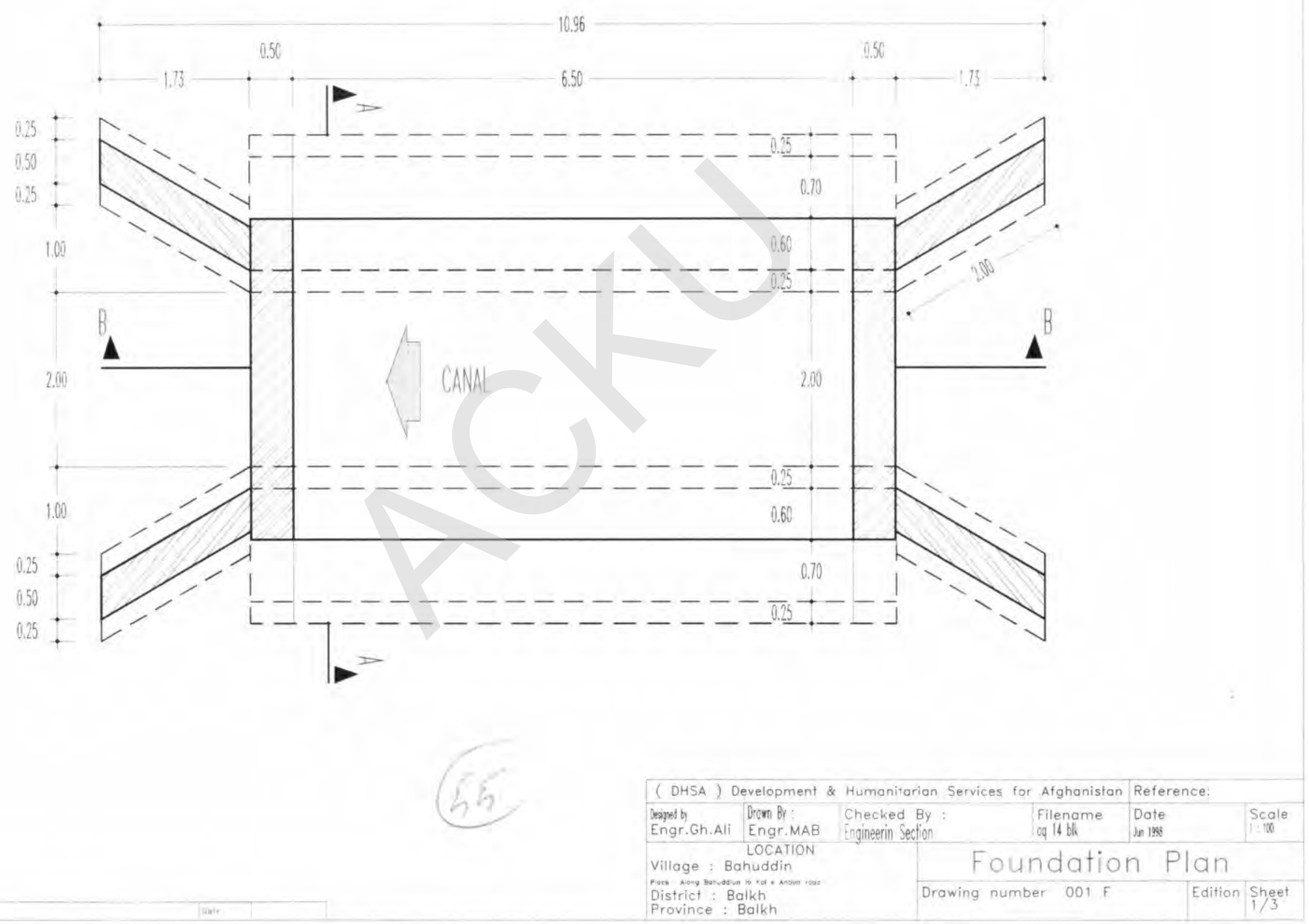



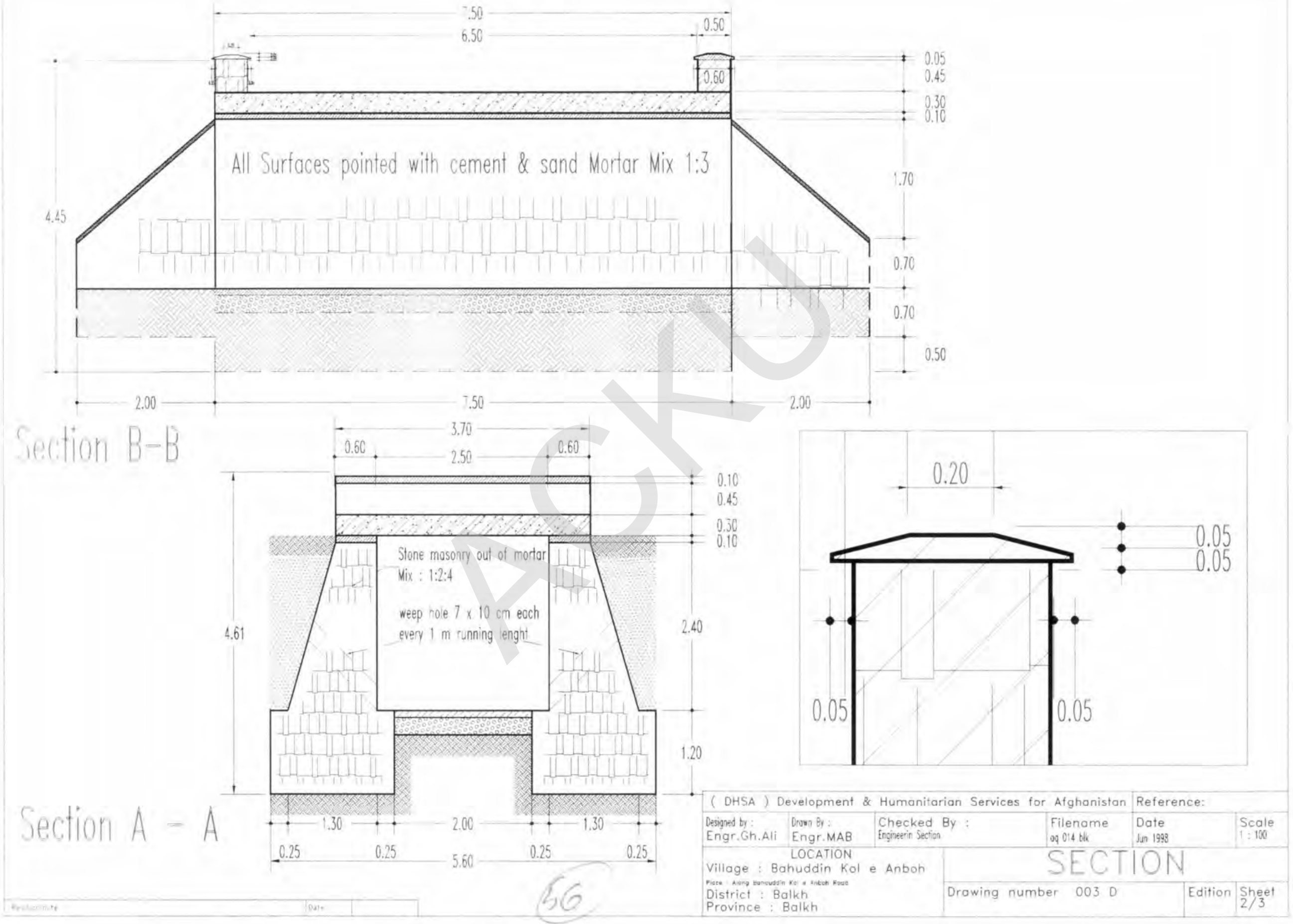


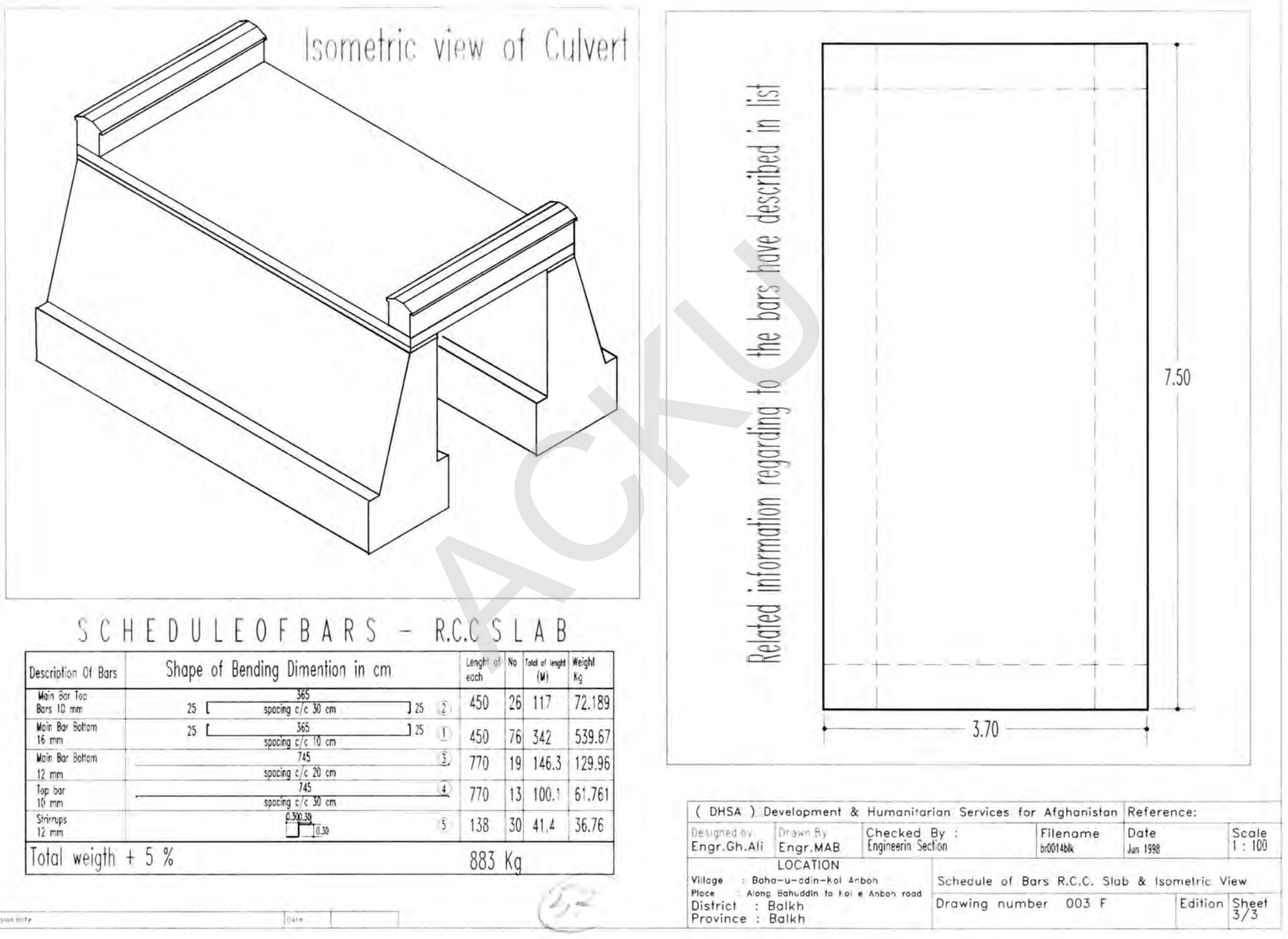




\section{ROAD - BRIDGES - CULVERTS}

Type of Project: Culvert $(1,4 \times 4 \times 1,9)$ \# 6 Location: Kole Anboh

District:Balkh

Province: Balkh

\begin{tabular}{|c|c|c|c|c|c|c|}
\hline No. & ITEMS & Unit & Number & Unit cost & Rs. & US\$ \\
\hline \multicolumn{7}{|c|}{1 - Expendable Material } \\
\hline 1 & Stone & $\mathrm{m} 3$ & 30 & 707 & 21210 & 481,98 \\
\hline 2 & Cement & bag & 71 & 325 & 23075 & 524,36 \\
\hline 3 & Sand \& Gravel & $\mathrm{m} 3$ & 15,59 & 707 & 11022 & 250,47 \\
\hline 4 & Sand & $\mathrm{m} 3$ & 1,5 & 707 & 1061 & 24,10 \\
\hline 5 & Wooden Beam 2m & nos & 45 & 144 & 6480 & 147,25 \\
\hline 6 & Wooden Plank $(2.5 \mathrm{~cm})$ & nos & 45 & 150 & 6750 & 153,39 \\
\hline 7 & Steel Bar & $\mathrm{kg}$ & 224 & 50 & 11200 & 254,51 \\
\hline 8 & Bending Wire & $\mathrm{kg}$ & 1,5 & 100 & 150 & 3,41 \\
\hline 9 & Nail & $\mathrm{kg}$ & 3 & 50 & 150 & 3,41 \\
\hline 10 & Transport cost & Lumpsum & & & 10212 & 232,06 \\
\hline \multicolumn{4}{|c|}{ Sub-total } & & 91310 & 2074,94 \\
\hline \multicolumn{7}{|c|}{2 - Non-expendable Material } \\
\hline 11 & Tools & Lumpsum & - & 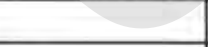 & 2840 & 64,54 \\
\hline \multicolumn{5}{|c|}{ Sub-total } & 2840 & 64,54 \\
\hline \multicolumn{7}{|c|}{3 - Labor } \\
\hline 12 & Skilled Labor & $\mathrm{m} / \mathrm{d}$ & 42 & 200 & 8400 & 190,88 \\
\hline 13 & Unskilled Labor & $\mathrm{m} / \mathrm{d}$ & 68 & 85 & 5780 & 131,35 \\
\hline \multicolumn{5}{|c|}{ Sub-total } & 14180 & 322,23 \\
\hline \multicolumn{5}{|c|}{ TOTAL } & 108329,63 & 2461,70 \\
\hline
\end{tabular}




\section{ROAD - BRIDGES - CULVERTS}

Type of Project: Culvert $(1,4 \times 4 \times 1,9) \# 8$

Location: Qariae Taligak
District:Dawlatabad

Province: Balkh

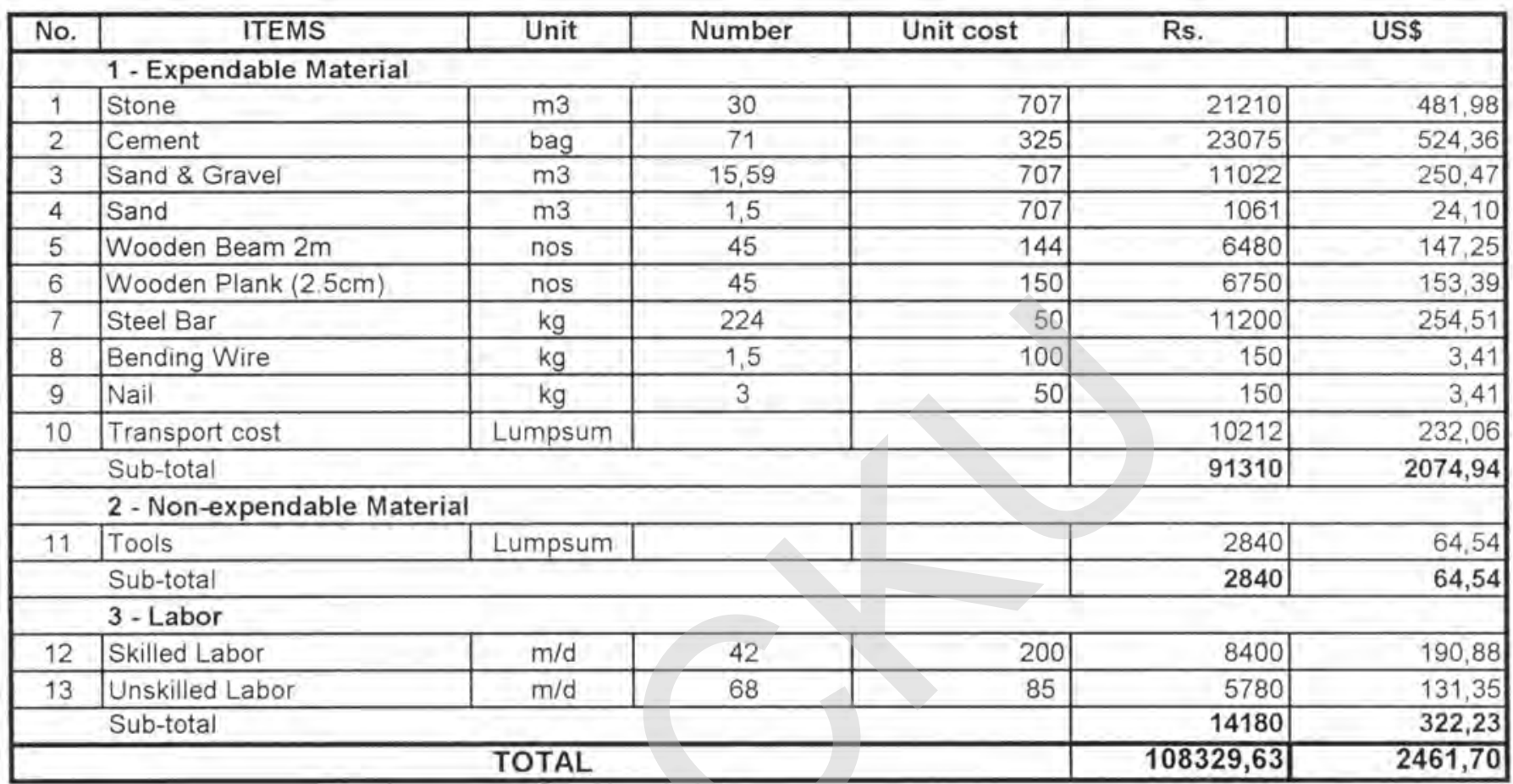




\section{ROAD - BRIDGES - CULVERTS}

Type of Project: Culvert $(1,4 \times 4 \times 1,9)$ \# 9

District:Dawlatabad

Location: Qariae Taligak

Province: Balkh

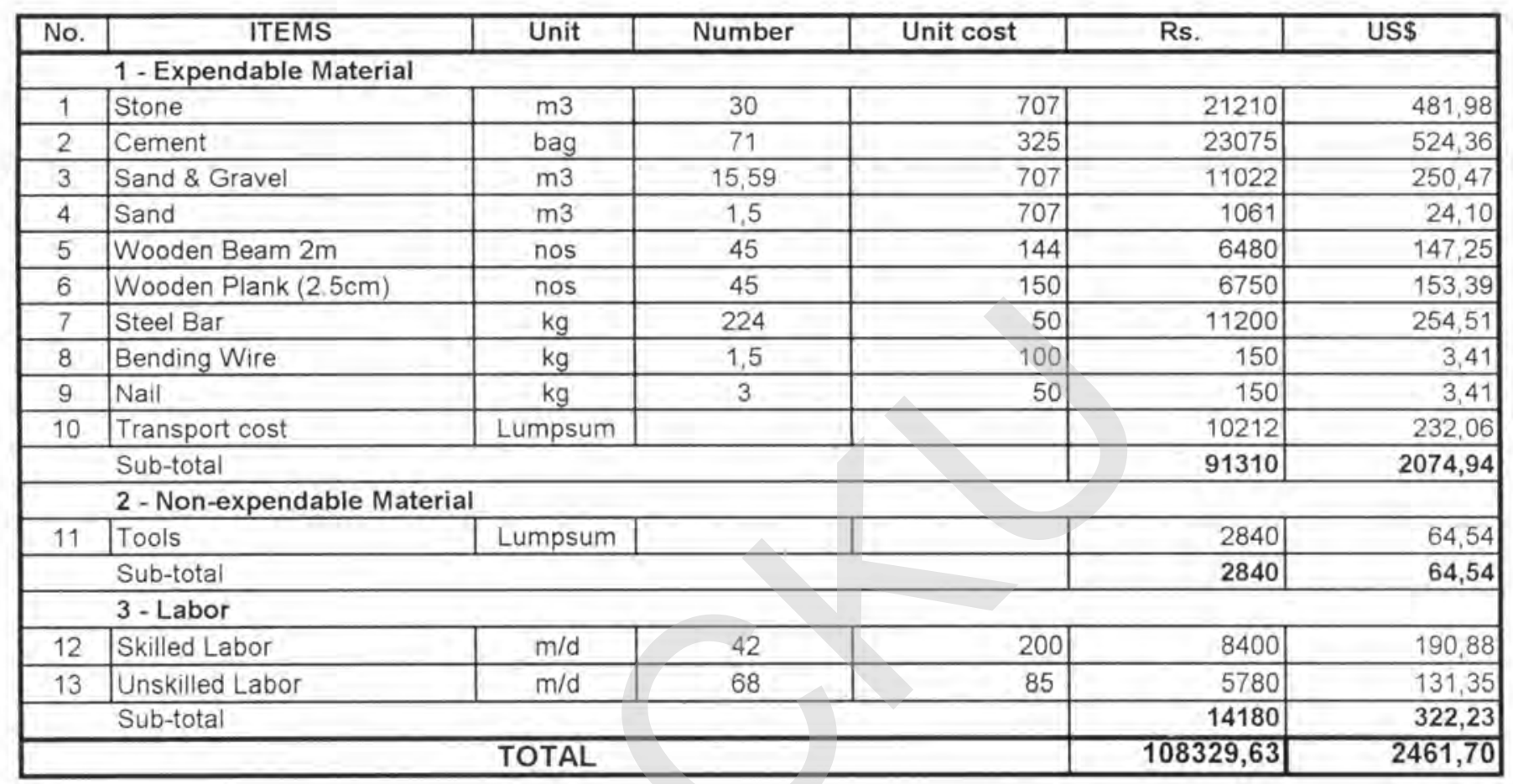




\section{ROAD - BRIDGES - CULVERTS}

Type of Project: Culvert $(1,4 \times 4 \times 1,9)$ \# 10 Location: Qariae Taligak

District:Dawlatabad

Province: Balkh

\begin{tabular}{|c|c|c|c|c|c|c|}
\hline No. & ITEMS & Unit & Number & Unit cost & Rs. & US\$ \\
\hline \multicolumn{7}{|c|}{ 1- Expendable Material } \\
\hline 1 & Stone & $\mathrm{m} 3$ & 30 & 707 & 21210 & 481,98 \\
\hline 2 & Cement & bag & 71 & 325 & 23075 & 524,36 \\
\hline 3 & Sand \& Gravel & $\mathrm{m3}$ & 15,59 & 707 & 11022 & 250,47 \\
\hline 4 & Sand & m3 & 1,5 & 707 & 1061 & 24,10 \\
\hline 5 & Wooden Beam 2m & nos & 45 & 144 & 6480 & 147,25 \\
\hline 6 & Wooden Plank $(2.5 \mathrm{~cm})$ & nos & 45 & 150 & 6750 & 153,39 \\
\hline 7 & Steel Bar & $\mathrm{kg}$ & 224 & 50 & 11200 & 254,51 \\
\hline 8 & Bending Wire & $\mathrm{kg}$ & 1,5 & 100 & 150 & 3,41 \\
\hline 9 & Nail & $\mathrm{kg}$ & 3 & 50 & 150 & 3,41 \\
\hline 10 & Transport cost & Lumpsum & & 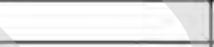 & 10212 & 232,06 \\
\hline \multicolumn{4}{|c|}{ Sub-total } & - & 91310 & 2074,94 \\
\hline \multicolumn{7}{|c|}{2 - Non-expendable Material } \\
\hline 11 & Tools & Lumpsum & & 3 & 2840 & 64,54 \\
\hline \multicolumn{5}{|c|}{ Sub-total } & 2840 & 64,54 \\
\hline \multicolumn{7}{|c|}{3 - Labor } \\
\hline 12 & Skilled Labor & $\mathrm{m} / \mathrm{d}$ & 42 & 200 & 8400 & 190,88 \\
\hline 13 & Unskilled Labor & $\mathrm{m} / \mathrm{d}$ & 68 & 85 & 5780 & 131,35 \\
\hline \multirow{2}{*}{\multicolumn{5}{|c|}{ Sub-total }} & 14180 & 322,23 \\
\hline & & & & & 108329,63 & 2461,70 \\
\hline
\end{tabular}




\section{ROAD - BRIDGES - CULVERTS}

Type of Project: Culvert $(1,4 \times 4 \times 1,9)$ \# 11 Location: Qariae Taligak

District:Dawlatabad Province: Balkh

\begin{tabular}{|c|c|c|c|c|c|c|}
\hline No. & ITEMS & Unit & Number & Unit cost & Rs. & US\$ \\
\hline & \multicolumn{6}{|l|}{1 - Expendable Material } \\
\hline 1 & Stone & $\mathrm{m} 3$ & 30 & 707 & 21210 & 481,98 \\
\hline 2 & Cement & bag & 71 & 325 & 23075 & 524,36 \\
\hline 3 & Sand \& Gravel & $\mathrm{m} 3$ & 15,59 & 707 & 11022 & 250,47 \\
\hline 4 & Sand & $\mathrm{m} 3$ & 1,5 & 707 & 1061 & 24,10 \\
\hline 5 & Wooden Beam $2 \mathrm{~m}$ & nos & 45 & 144 & 6480 & 147,25 \\
\hline 6 & Wooden Plank $(2.5 \mathrm{~cm})$ & nos & 45 & 150 & 6750 & 153,39 \\
\hline 7 & Steel Bar & $\mathrm{kg}$ & 224 & 50 & 11200 & 254,51 \\
\hline 8 & Bending Wire & $\mathrm{kg}$ & 1,5 & 100 & 150 & 3,41 \\
\hline 9 & Nail & $\mathrm{kg}$ & 3 & 50 & 150 & 3,41 \\
\hline \multirow[t]{3}{*}{10} & Transport cost & Lumpsum & & & 10212 & 232,06 \\
\hline & \multicolumn{3}{|l|}{ Sub-total } & 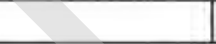 & 91310 & 2074,94 \\
\hline & \multicolumn{3}{|c|}{2 - Non-expendable Material } & & & \\
\hline 11 & Tools & Lumpsum & & & 2840 & 64,54 \\
\hline & \multicolumn{4}{|l|}{ Sub-total } & 2840 & 64,54 \\
\hline & \multicolumn{6}{|l|}{3 -Labor } \\
\hline 12 & Skilled Labor & $\mathrm{m} / \mathrm{d}$ & 42 & 200 & 8400 & 190,88 \\
\hline 13 & Unskilled Labor & $\mathrm{m} / \mathrm{d}$ & 68 & 85 & 5780 & 131,35 \\
\hline & \multirow{2}{*}{\multicolumn{4}{|c|}{ Sub-total }} & 14180 & 322,23 \\
\hline & & & & & 108329,63 & 2461,70 \\
\hline
\end{tabular}




\section{ROAD - BRIDGES - CULVERTS}

Type of Project: Culvert $(1,4 \times 4 \times 1,9)$ \# 11

Location: Qariae Taligak

District:Dawlatabad

Province: Balkh

\begin{tabular}{|c|c|c|c|c|c|c|}
\hline No. & ITEMS & Unit & Number & Unit cost & Rs. & US\$ \\
\hline \multicolumn{7}{|c|}{ 1- Expendable Material } \\
\hline 1 & Stone & m3 & 30 & 707 & 21210 & 481,98 \\
\hline 2 & Cement & bag & 71 & 325 & 23075 & 524,36 \\
\hline 3 & Sand \& Gravel & $\mathrm{m} 3$ & 15,59 & 707 & 11022 & 250,47 \\
\hline 4 & Sand & $\mathrm{m} 3$ & 1,5 & 707 & 1061 & 24,10 \\
\hline 5 & Wooden Beam $2 \mathrm{~m}$ & nos & 45 & 144 & 6480 & 147,25 \\
\hline 6 & Wooden Plank $(2.5 \mathrm{~cm})$ & nos & 45 & 150 & 6750 & 153,39 \\
\hline 7 & Steel Bar & $\mathrm{kg}$ & 224 & 50 & 11200 & 254,51 \\
\hline 8 & Bending Wire & $\mathrm{kg}$ & 1,5 & 100 & 150 & 3,41 \\
\hline 9 & Nail & $\mathrm{kg}$ & 3 & 50 & 150 & 3,41 \\
\hline 10 & Transport cost & Lumpsum & & 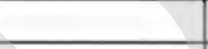 & 10212 & 232,06 \\
\hline \multicolumn{5}{|c|}{ Sub-total } & 91310 & 2074,94 \\
\hline \multicolumn{7}{|c|}{2 - Non-expendable Material } \\
\hline 11 & Tools & Lumpsum & & & 2840 & 64,54 \\
\hline \multicolumn{5}{|c|}{ Sub-total } & 2840 & 64,54 \\
\hline \multicolumn{7}{|c|}{3 - Labor } \\
\hline 12 & Skilled Labor & $\mathrm{m} / \mathrm{d}$ & 42 & 200 & 8400 & 190,88 \\
\hline 13 & Unskilled Labor & $\mathrm{m} / \mathrm{d}$ & 68 & 85 & 5780 & 131,35 \\
\hline \multicolumn{5}{|c|}{ Sub-total } & 14180 & 322,23 \\
\hline \multicolumn{5}{|c|}{ TOTAL } & 108329,63 & 2461,70 \\
\hline
\end{tabular}




\section{ROAD - BRIDGES - CULVERTS}

Type of Project: Culvert $(1,4 \times 4 \times 1,9) \# 12$ Location: Qariae Taligak

District:Dawlatabad Province: Balkh

\begin{tabular}{|c|c|c|c|c|c|c|}
\hline No. & ITEMS & Unit & Number & Unit cost & Rs. & US\$ \\
\hline \multicolumn{7}{|c|}{ 1-Expendable Material } \\
\hline 1 & Stone & m3 & 30 & 707 & 21210 & 481,98 \\
\hline 2 & Cement & bag & 71 & 325 & 23075 & 524,36 \\
\hline 3 & Sand \& Gravel & m3 & 15,59 & 707 & 11022 & 250,47 \\
\hline 4 & Sand & $\mathrm{m3}$ & 1,5 & 707 & 1061 & 24,10 \\
\hline 5 & Wooden Beam 2m & nos & 45 & 144 & 6480 & 147,25 \\
\hline 6 & Wooden Plank $(2.5 \mathrm{~cm})$ & nos & 45 & 150 & 6750 & 153,39 \\
\hline 7 & Steel Bar & $\mathrm{kg}$ & 224 & 50 & 11200 & 254,51 \\
\hline 8 & Bending Wire & $\mathrm{kg}$ & 1,5 & 100 & 150 & 3,41 \\
\hline 9 & Nail & $\mathrm{kg}$ & 3 & 50 & 150 & 3,41 \\
\hline 10 & Transport cost & Lumpsum & & 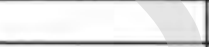 & 10212 & 232,06 \\
\hline \multicolumn{4}{|c|}{ Sub-total } & & 91310 & 2074,94 \\
\hline \multicolumn{7}{|c|}{2 - Non-expendable Material } \\
\hline 11 & Tools & Lumpsum & & & 2840 & 64,54 \\
\hline \multicolumn{5}{|c|}{ Sub-total } & 2840 & 64,54 \\
\hline \multicolumn{7}{|c|}{ 3-Labor } \\
\hline 12 & Skilled Labor & $\mathrm{m} / \mathrm{d}$ & 42 & 200 & 8400 & 190,88 \\
\hline 13 & Unskilled Labor & $\mathrm{m} / \mathrm{d}$ & 68 & 85 & 5780 & 131,35 \\
\hline \multicolumn{5}{|c|}{ Sub-total } & 14180 & 322,23 \\
\hline \multicolumn{5}{|c|}{ TOTAL } & 108329,63 & 2461,70 \\
\hline
\end{tabular}




\section{ROAD - BRIDGES - CULVERTS}

Type of Project: Culvert $(1,4 \times 4 \times 1,9) \# 13$

Location: Qariae Taligak

District:Dawlatabad

Province: Balkh

\begin{tabular}{|c|c|c|c|c|c|c|}
\hline No. & ITEMS & Unit & Number & Unit cost & Rs. & US\$ \\
\hline \multicolumn{7}{|c|}{1 - Expendable Material } \\
\hline 1 & Stone & m3 & 30 & 707 & 21210 & 481,98 \\
\hline 2 & Cement & bag & 71 & 325 & 23075 & 524,36 \\
\hline 3 & Sand \& Gravel & $\mathrm{m} 3$ & 15,59 & 707 & 11022 & 250,47 \\
\hline 4 & Sand & $\mathrm{m} 3$ & 1,5 & 707 & 1061 & 24,10 \\
\hline 5 & Wooden Beam $2 \mathrm{~m}$ & nos & 45 & 144 & 6480 & 147,25 \\
\hline 6 & Wooden Plank $(2.5 \mathrm{~cm})$ & nos & 45 & 150 & 6750 & 153,39 \\
\hline 7 & Steel Bar & $\mathrm{kg}$ & 224 & 50 & 11200 & 254,51 \\
\hline 8 & Bending Wire & $\mathrm{kg}$ & 1,5 & 100 & 150 & 3,41 \\
\hline 9 & Nail & $\mathrm{kg}$ & 3 & 50 & 150 & 3,41 \\
\hline 10 & Transport cost & Lumpsum & & - & 10212 & 232,06 \\
\hline \multicolumn{4}{|c|}{ Sub-total } & & 91310 & 2074,94 \\
\hline \multicolumn{7}{|c|}{2 - Non-expendable Material } \\
\hline 11 & Tools & Lumpsum & & 2 & 2840 & 64,54 \\
\hline \multicolumn{5}{|c|}{ Sub-total } & 2840 & 64,54 \\
\hline \multicolumn{7}{|c|}{ 3-Labor } \\
\hline 12 & Skilled Labor & $\mathrm{m} / \mathrm{d}$ & 42 & 200 & 8400 & 190,88 \\
\hline 13 & Unskilled Labor & $\mathrm{m} / \mathrm{d}$ & 68 & 85 & 5780 & 131,35 \\
\hline \multicolumn{5}{|c|}{ Sub-total } & 14180 & 322,23 \\
\hline & & TOTAL & & & 108329,63 & 2461,70 \\
\hline
\end{tabular}




\section{ROAD - BRIDGES - CULVERTS}

Type of Project: Culvert $(1,4 \times 4 \times 1,9) \# 14$

District:Dawlatabad

Location: Qariae Taligak

Province: Balkh

\begin{tabular}{|c|c|c|c|c|c|c|}
\hline No. & ITEMS & Unit & Number & Unit cost & Rs. & US\$ \\
\hline \multicolumn{7}{|c|}{ 1-Expendable Material } \\
\hline 1 & Stone & $\mathrm{m3}$ & 30 & 707 & 21210 & 481,98 \\
\hline 2 & Cement & bag & 71 & 325 & 23075 & 524,36 \\
\hline 3 & Sand \& Gravel & $\mathrm{m} 3$ & 15,59 & 707 & 11022 & 250,47 \\
\hline 4 & Sand & m3 & 1,5 & 707 & 1061 & 24,10 \\
\hline 5 & Wooden Beam 2m & nos & 45 & 144 & 6480 & 147,25 \\
\hline 6 & Wooden Plank $(2.5 \mathrm{~cm})$ & nos & 45 & 150 & 6750 & 153,39 \\
\hline 7 & Steel Bar & $\mathrm{kg}$ & 224 & 50 & 11200 & 254,51 \\
\hline 8 & Bending Wire & $\mathrm{kg}$ & 1,5 & 100 & 150 & 3,41 \\
\hline 9 & Nail & $\mathrm{kg}$ & 3 & 50 & 150 & 3,41 \\
\hline 10 & Transport cost & Lumpsum & & 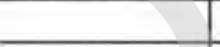 & 10212 & 232,06 \\
\hline \multicolumn{4}{|c|}{ Sub-total } & & 91310 & 2074,94 \\
\hline \multicolumn{7}{|c|}{2 - Non-expendable Material } \\
\hline 11 & Tools & Lumpsum & & & 2840 & 64,54 \\
\hline \multicolumn{5}{|c|}{ Sub-total } & 2840 & 64,54 \\
\hline \multicolumn{7}{|c|}{3 -Labor } \\
\hline 12 & Skilled Labor & $\mathrm{m} / \mathrm{d}$ & 42 & 200 & 8400 & 190,88 \\
\hline 13 & Unskilled Labor & $\mathrm{m} / \mathrm{d}$ & 68 & 85 & 5780 & 131,35 \\
\hline \multirow{2}{*}{\multicolumn{5}{|c|}{ Sub-total }} & 14180 & 322,23 \\
\hline \multicolumn{4}{|c|}{ TOTAL } & & 108329,63 & 2461,70 \\
\hline
\end{tabular}




\section{ROAD - BRIDGES - CULVERTS}

Type of Project: Culvert $(1,4 \times 4 \times 1,9) \# 15$ Location: Qariae Taligak

District:Dawlatabad

Province: Balkh

\begin{tabular}{|c|c|c|c|c|c|c|}
\hline No. & ITEMS & Unit & Number & Unit cost & Rs. & US\$ \\
\hline \multicolumn{7}{|c|}{ 1-Expendable Material } \\
\hline 1 & Stone & $\mathrm{m} 3$ & 30 & 707 & 21210 & 481,98 \\
\hline 2 & Cement & bag & 71 & 325 & 23075 & 524,36 \\
\hline 3 & Sand \& Gravel & m3 & 15,59 & 707 & 11022 & 250,47 \\
\hline 4 & Sand & $\mathrm{m} 3$ & 1,5 & 707 & 1061 & 24,10 \\
\hline 5 & Wooden Beam $2 \mathrm{~m}$ & nos & 45 & 144 & 6480 & 147,25 \\
\hline 6 & Wooden Plank $(2.5 \mathrm{~cm})$ & nos & 45 & 150 & 6750 & 153,39 \\
\hline 7 & Steel Bar & $\mathrm{kg}$ & 224 & 50 & 11200 & 254,51 \\
\hline 8 & Bending Wire & $\mathrm{kg}$ & 1,5 & 100 & 150 & 3,41 \\
\hline 9 & Nail & $\mathrm{kg}$ & 3 & 50 & 150 & 3,41 \\
\hline 10 & Transport cost & Lumpsum & & & 10212 & 232,06 \\
\hline \multicolumn{5}{|c|}{ Sub-total } & 91310 & 2074,94 \\
\hline \multicolumn{7}{|c|}{2 - Non-expendable Material } \\
\hline 11 & Tools & Lumpsum & . & 2 & 2840 & 64,54 \\
\hline \multicolumn{5}{|c|}{ Sub-total } & 2840 & 64,54 \\
\hline \multicolumn{7}{|c|}{ 3-Labor } \\
\hline 12 & Skilled Labor & $\mathrm{m} / \mathrm{d}$ & 42 & 200 & 8400 & 190,88 \\
\hline 13 & Unskilled Labor & $\mathrm{m} / \mathrm{d}$ & 68 & 85 & 5780 & 131,35 \\
\hline \multicolumn{5}{|c|}{ Sub-total } & 14180 & 322,23 \\
\hline & & TOTAL & & & 108329,63 & 2461,70 \\
\hline
\end{tabular}


ROAD - BRIDGES - CULVERTS

Type of Project: Culvert $(1,4 \times 4 \times 1,9) \# 16$

District:Dawlatabad

Location: Qarshigak

Province: Balkh

\begin{tabular}{|c|c|c|c|c|c|c|}
\hline No. & ITEMS & Unit & Number & Unit cost & Rs. & US\$ \\
\hline \multicolumn{7}{|c|}{ 1- Expendable Material } \\
\hline 1 & Stone & $\mathrm{m} 3$ & 30 & 707 & 21210 & 481,98 \\
\hline 2 & Cement & bag & 71 & 325 & 23075 & 524,36 \\
\hline 3 & Sand \& Gravel & $\mathrm{m} 3$ & 15,59 & 707 & 11022 & 250,47 \\
\hline 4 & Sand & m3 & 1,5 & 707 & 1061 & 24,10 \\
\hline 5 & Wooden Beam 2m & nos & 45 & 144 & 6480 & 147,25 \\
\hline 6 & Wooden Plank $(2.5 \mathrm{~cm})$ & nos & 45 & 150 & 6750 & 153,39 \\
\hline 7 & Steel Bar & $\mathrm{kg}$ & 224 & 50 & 11200 & 254,51 \\
\hline 8 & Bending Wire & $\mathrm{kg}$ & 1,5 & 100 & 150 & 3,41 \\
\hline 9 & Nail & $\mathrm{kg}$ & 3 & 50 & 150 & 3,41 \\
\hline 10 & Transport cost & Lumpsum & & & 10212 & 232,06 \\
\hline \multicolumn{4}{|c|}{ Sub-total } & & 91310 & 2074,94 \\
\hline \multicolumn{7}{|c|}{ 2- Non-expendable Material } \\
\hline 11 & Tools & Lumpsum & & & 2840 & 64,54 \\
\hline \multicolumn{5}{|c|}{ Sub-total } & 2840 & 64,54 \\
\hline \multicolumn{7}{|c|}{3 -Labor } \\
\hline 12 & Skilled Labor & $\mathrm{m} / \mathrm{d}$ & 42 & 200 & 8400 & 190,88 \\
\hline 13 & Unskilled Labor & $\mathrm{m} / \mathrm{d}$ & 68 & 85 & 5780 & 131,35 \\
\hline \multirow{2}{*}{\multicolumn{3}{|c|}{ Sub-total }} & & & 14180 & 322,23 \\
\hline & & & & & 108329,63 & 2461,70 \\
\hline
\end{tabular}




\section{ROAD - BRIDGES - CULVERTS}

Type of Project: Culvert $(1,4 \times 4 \times 1,9) \# 17$

District:Dawlatabad

Location: Qarshigak

Province: Balkh

\begin{tabular}{|c|c|c|c|c|c|c|}
\hline No. & ITEMS & Unit & Number & Unit cost & Rs. & US\$ \\
\hline & \multicolumn{6}{|l|}{ 1-Expendable Material } \\
\hline 1 & Stone & $\mathrm{m} 3$ & 30 & 707 & 21210 & 481,98 \\
\hline 2 & Cement & bag & 71 & 325 & 23075 & 524,36 \\
\hline 3 & Sand \& Gravel & $\mathrm{m} 3$ & 15,59 & 707 & 11022 & 250,47 \\
\hline 4 & Sand & $\mathrm{m} 3$ & 1,5 & 707 & 1061 & 24,10 \\
\hline 5 & Wooden Beam $2 \mathrm{~m}$ & nos & 45 & 144 & 6480 & 147,25 \\
\hline 6 & Wooden Plank $(2.5 \mathrm{~cm})$ & nos & 45 & 150 & 6750 & 153,39 \\
\hline 7 & Steel Bar & $\mathrm{kg}$ & 224 & 50 & 11200 & 254,51 \\
\hline 8 & Bending Wire & $\mathrm{kg}$ & 1,5 & 100 & 150 & 3,41 \\
\hline 9 & Nail & $\mathrm{kg}$ & 3 & 50 & 150 & 3,41 \\
\hline \multirow[t]{3}{*}{10} & Transport cost & Lumpsum & & & 10212 & 232,06 \\
\hline & \multicolumn{3}{|c|}{ Sub-total } & & 91310 & 2074,94 \\
\hline & \multicolumn{6}{|c|}{2 - Non-expendable Material } \\
\hline 11 & Tools & Lumpsum & $\Delta$ & & 2840 & 64,54 \\
\hline & \multicolumn{4}{|l|}{ Sub-total } & 2840 & 64,54 \\
\hline & \multicolumn{6}{|l|}{3 - Labor } \\
\hline 12 & Skilled Labor & $\mathrm{m} / \mathrm{d}$ & 42 & 200 & 8400 & 190,88 \\
\hline 13 & Unskilled Labor & $\mathrm{m} / \mathrm{d}$ & 68 & 85 & 5780 & 131,35 \\
\hline & \multirow{2}{*}{\multicolumn{4}{|c|}{ Sub-total }} & 14180 & 322,23 \\
\hline & & & & & 108329,63 & 2461,70 \\
\hline
\end{tabular}




\section{Foundation Plan}

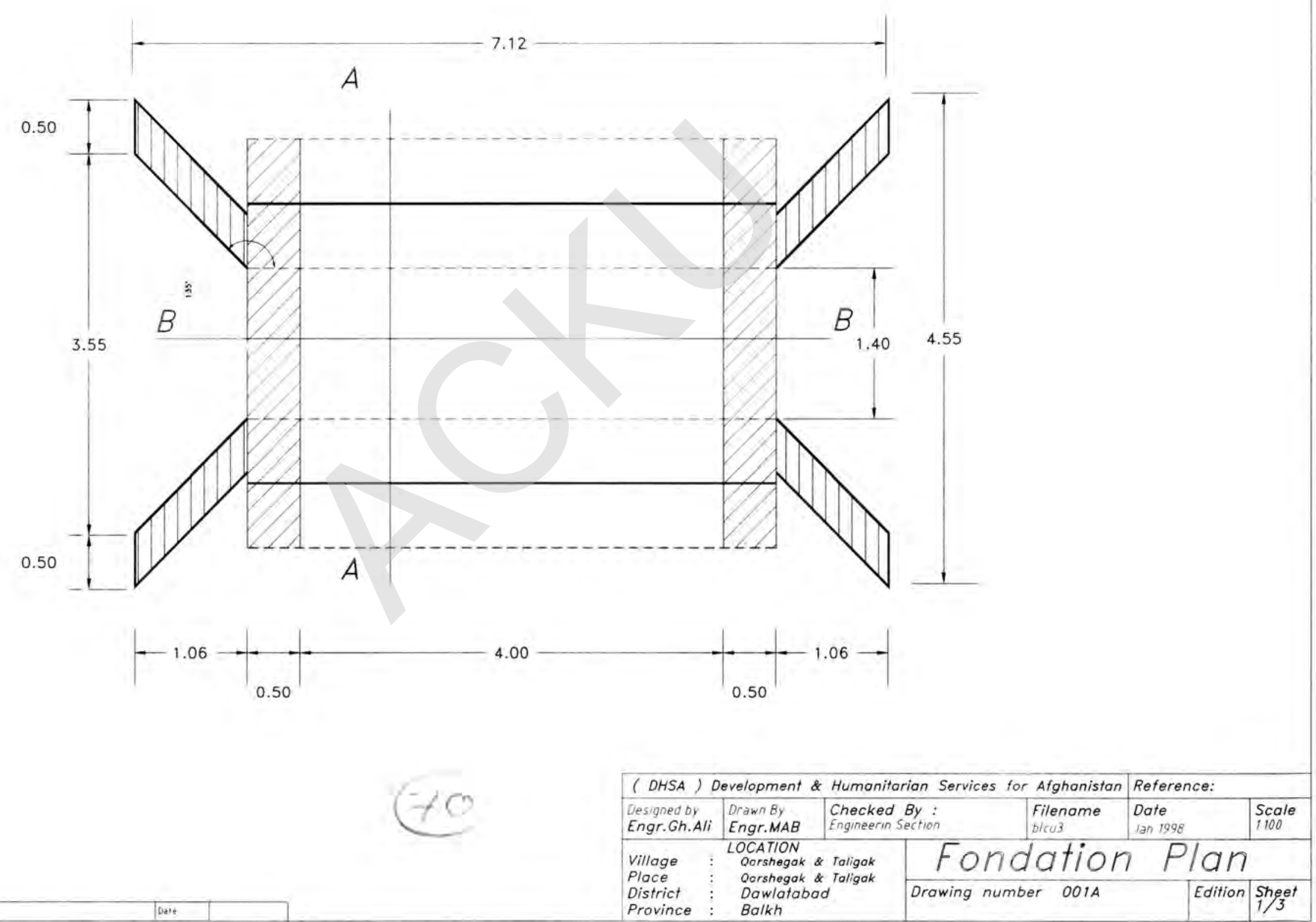




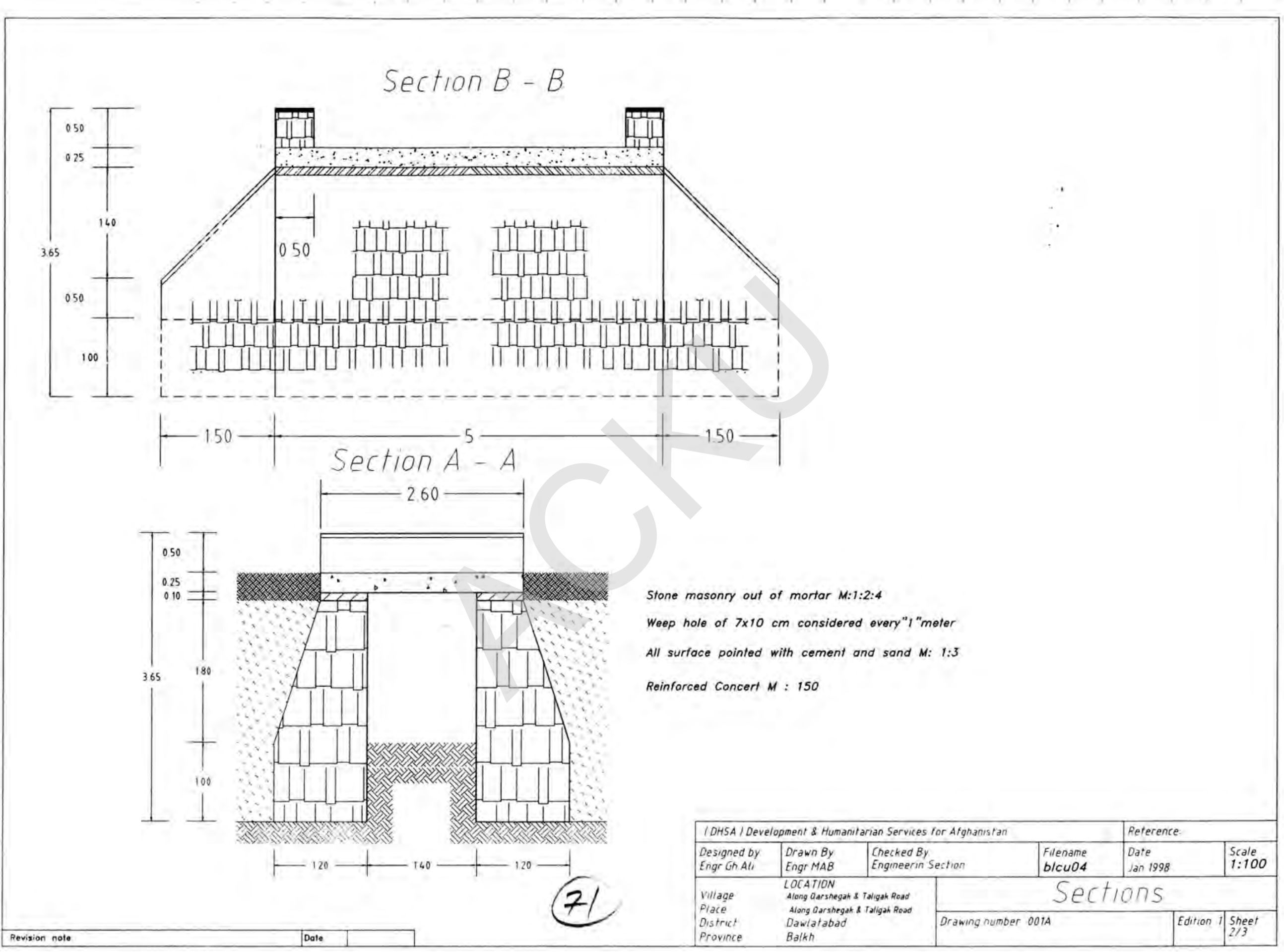




\section{Schedule of Bars}

\begin{tabular}{|c|c|c|c|c|c|}
\hline cascribation of arr & ENGm or EACM & No & 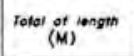 & $\operatorname{mog}(\mathrm{gam}(\mathrm{kg})$ & Shape of Bending Dimention in $\mathrm{m}, \mathrm{cm}$ \\
\hline Botrom Bor & 500 & ou. $14 \mathrm{~mm}$ & ss & 6.4. & 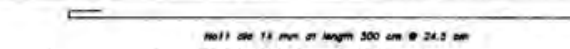 \\
\hline Bottam Bor & 500 & DAA. $18 \mathrm{~mm}$ & 48 & 75.7. & 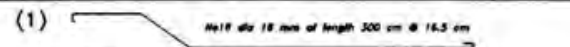 \\
\hline sottrom sor & 300 & Du. $16 \mathrm{~mm}$ & s & 75.) & 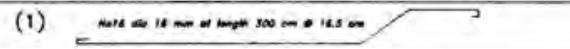 \\
\hline Tos Bor & 500 & on. $1 \mathrm{mmm}$ & ss & 3 & 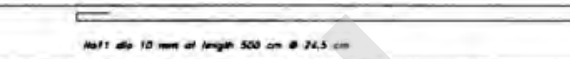 \\
\hline rep Aar & 300 & ou. $10 \mathrm{~mm}$ & 33 & 20.3 & $=$ \\
\hline DTAR weigrm & & & & 224 & \\
\hline
\end{tabular}

32 No dio.16 mm of length $300,016.6 \quad 11$ dio $14 \mathrm{~mm}$ af length $500 \mathrm{~cm}$ ๑ $25 \mathrm{~cm}$ 000000000060000000000000000 No16 dio $16 \mathrm{~mm}$ at length $300 \mathrm{~cm} \bullet 12.5 \mathrm{~cm}$

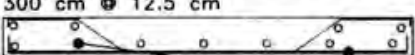

\section{(2) No16 dia $16 \mathrm{~mm}$ at lentig $300 \mathrm{~cm}$. $16.5 \mathrm{~cm}$}
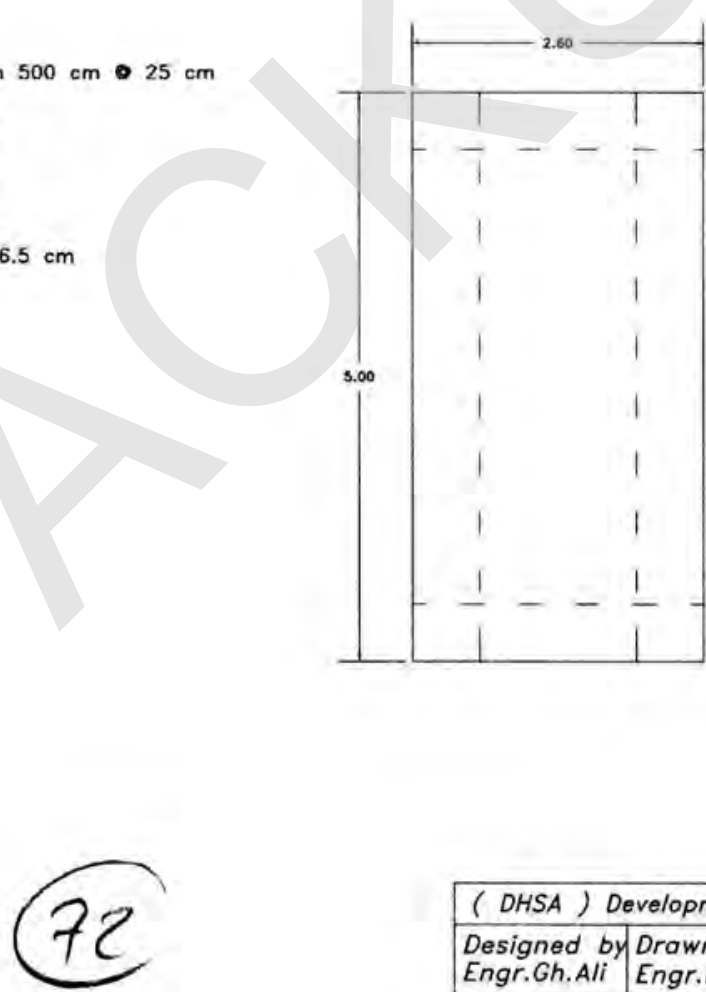

( DHSA ) Development \& Humanitarian Services for Afghanistan Reference:

Designed by Drawn By: Checked By: $\quad$ Filename Date

Scale

Engr.Gh.Ali Engr.MAB

LOCATION

Schedule of Steel

Bars

Village : Along Karshogak \& Tallsak

Place
District : Along Qarsheg
Pawlatabad Drawing number 001 
AGRICULTURE

FRUIT TREES NURSERY

Five ieribs land ( 85,000 saplings)

\begin{tabular}{|c|c|c|c|c|c|c|c|}
\hline No. & ITEMS & Unit & Number & Period & Unit cost & Rs. & US\$ \\
\hline 1 & Land lease & Jerib & 5 & 3 & 14300 & 214500 & 4874,34 \\
\hline 2 & Seeds & $\mathrm{Kg}$ & 100 & 1 & 150 & 15000 & 340,86 \\
\hline 3 & Cultivation cost & Jerib & 5 & 1 & 3350 & 16750 & 380,63 \\
\hline 4 & Animal fertilizer & Truck & 10 & 1 & 1500 & 15000 & 340,86 \\
\hline 5 & Weeding & Time & 5 & 5 & 2850 & 71250 & 1619,10 \\
\hline 6 & Fertilizer (urea) & Bags & 5 & 2 & 540 & 5400 & 122,71 \\
\hline 7 & Fertilizer (DAP) & Bags & 5 & 2 & 750 & 7500 & 170,43 \\
\hline 8 & Pesticides & $\mathrm{Lt} . / \mathrm{Kg}$ & 10 & 1 & 300 & 3000 & 68,17 \\
\hline 9 & Sulfur & Bags & 2 & 1 & 1000 & 2000 & 45,45 \\
\hline 10 & Grafting & Per tree & 100000 & 1 & 1,3 & 130000 & 2954,14 \\
\hline 11 & Gardener & Person & 3 & 24 & 2500 & 180000 & 4090,35 \\
\hline 12 & Field supervisor & Person & 1 & 24 & 3000 & 72000 & 1636,14 \\
\hline 13 & Protection wall & Jerib & 5 & 1 & 10200 & 51000 & 1158,93 \\
\hline 14 & Tools & Set & 5 & 1 & 3000 & 15000 & 340,86 \\
\hline 15 & Transportation cost & & 1 & 5 & 1500 & 7500 & 170,43 \\
\hline \multicolumn{2}{|c|}{ SUB-TOTAL NURSERY } & & & & & 805900 & 18313,41 \\
\hline
\end{tabular}


SOCIAL WELFARE PROGRAM

MAZAR'S ASHIANA

1. OPERATIONAL

\begin{tabular}{l|l|l|l|l|}
\hline Unit & Number & Month & Unit Cost & Total Rs. \\
\hline
\end{tabular}

US\$

\begin{tabular}{|c|c|c|c|c|c|c|}
\hline 1 & Manager & 1 & 10 & 5000 & 50000 & 1136,21 \\
\hline 2 & Doctor (part time) & 1 & 10 & 2000 & 20000 & 454,48 \\
\hline 3 & Teacher/Social worker & 7 & 10 & 2500 & 175000 & 3976,73 \\
\hline 4 & Health educator & 1 & 10 & 2500 & 25000 & 568,10 \\
\hline 5 & Cook & 1 & 10 & 2000 & 20000 & 454,48 \\
\hline 6 & Cleaner & 1 & 10 & 1500 & 15000 & 340,86 \\
\hline 7 & Guard & 3 & 10 & 1500 & 45000 & 1022,59 \\
\hline & \multicolumn{4}{|l|}{ Sub-total } & 350000,0 & 7953,46 \\
\hline
\end{tabular}

\section{2- NON EXPENDABLES}

\begin{tabular}{|r|l|c|c|r|r|r|r|}
\hline 1 & Furniture & set & 1 & & 100000 & 100000 & 2272,42 \\
\hline 2 & Bicycle & each & 4 & & 3500 & 14000 & 318,14 \\
\hline 3 & Kitchen Utensils & set & 1 & & 13000 & 13000 & 295,41 \\
\hline & Sub-total & & 127000,0 & 2885,97 \\
\hline
\end{tabular}

\section{3- EXPENSES}

\begin{tabular}{|r|l|c|r|r|r|r|r|}
\hline 1 & House rent & month & 1 & 10 & 8000 & 80000 & 1817,93 \\
\hline 2 & Setup & time & 1 & 1 & 10000 & 10000 & 227,24 \\
\hline 3 & Energy & month & 1 & 10 & 3000 & 30000 & 681,73 \\
\hline 4 & Telephone & month & 1 & 10 & 250 & 2500 & 56,81 \\
\hline 5 & Electricity & month & 1 & 10 & 500 & 5000 & 113,62 \\
\hline 6 & Medicine & month & 1 & 10 & 1800 & 18000 & 409,04 \\
\hline 7 & Food & month & 1 & 10 & 24000 & 240000 & 5453,80 \\
\hline 8 & Hygiene Material & month & 1 & 10 & 4000 & 40000 & 908,97 \\
\hline 9 & Stationary & month & 1 & 10 & 1000 & 10000 & 227,24 \\
\hline 10 & Educational Material & month & 1 & 10 & 1000 & 10000 & 227,24 \\
\hline 11 & Transportation & month & 1 & 10 & 12000 & 120000 & 2726,90 \\
\hline 12 & Misc. & month & 1 & 10 & 2000 & 20000 & 454,48 \\
\hline & Sub-total & & & & $\mathbf{4 5 8 0 0 0 , 0}$ & $\mathbf{1 3 3 0 5 , 0 0}$ \\
\hline
\end{tabular}


LIST OF RETURNEES

IN BALKH PROVINCE 
List of Returnees from Neighboring Countries

Province: Balkh

District: Dawlatabad

Village: Sultan Khuja Wall

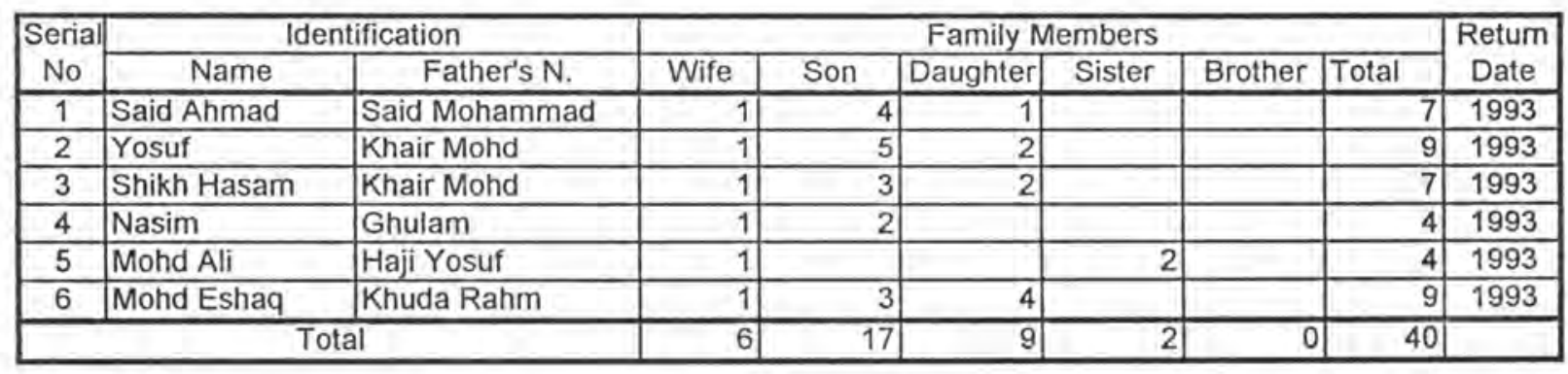

This village was situated near a military post during Russian occupation and almost completely leveled. 
List of Returnees from Neighboring Countries

Province: Balkh

District: Dawlatabad

Village: Bagh-e-Shur

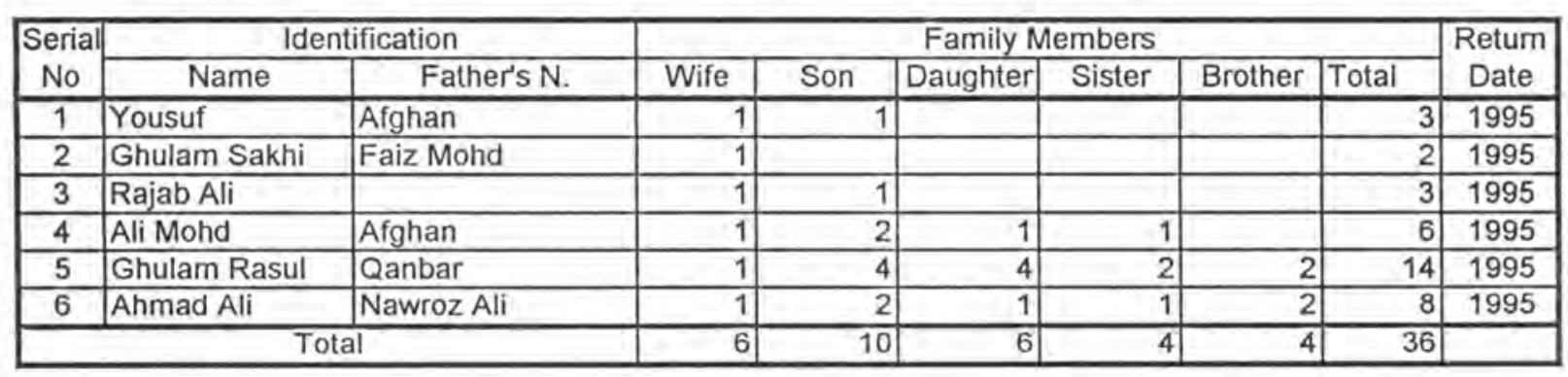

This village was situated near a military post during Russian occupation and almost completely leveled.

2 


\section{List of Returnees from Neighboring Countries}

Province: Balkh

District: Dawlatabad

Village: Saderabad

\begin{tabular}{|c|c|c|c|c|c|c|c|c|c|}
\hline \multirow{2}{*}{$\begin{array}{c}\text { Serial } \\
\text { No }\end{array}$} & \multicolumn{2}{|c|}{ Identification } & \multicolumn{6}{|c|}{ Family Members } & \multirow{2}{*}{\begin{tabular}{|c|} 
Return \\
Date
\end{tabular}} \\
\hline & Name & Father's N. & Wife & Son & Daughter & Sister & Brother & Total & \\
\hline 1 & Mohd Ishaq & Haji Haidar & 1 & 3 & 1 & & & 6 & 1993 \\
\hline 2 & Hussain & Haji Haidar & 1 & & & & & 2 & 1993 \\
\hline 3 & Ghulam Ali & Haji Haidar & 1 & 2 & 5 & & & 9 & 1993 \\
\hline 4 & Samad & Ghulam Ali & 1 & 2 & 2 & 1 & & 7 & 1993 \\
\hline 5 & Ewaz & Ghulam Ali & 1 & 5 & 2 & & & 9 & 1993 \\
\hline 6 & Ali Akbar & Awim & 1 & & & & & 2 & 1993 \\
\hline 7 & Hussain & Shefa & 1 & & & & & 2 & 1993 \\
\hline 8 & Hussain Ali & Ibrahim & 1 & 4 & & & & 6 & 1993 \\
\hline 9 & Nawroz & Barg Ali & 1 & 2 & 3 & & 1 & 8 & 1993 \\
\hline \multicolumn{3}{|c|}{ Total } & 9 & 18 & 13 & 1 & 1 & 51 & \\
\hline
\end{tabular}




\section{List of Returnees from Neighboring Countries}

Province: Balkh

District: Dawlatabad

Village: Aulang

\begin{tabular}{|c|c|c|c|c|c|c|c|c|c|}
\hline \multirow{2}{*}{$\begin{array}{c}\text { Serial } \\
\text { No }\end{array}$} & \multicolumn{2}{|c|}{ Identification } & \multicolumn{6}{|c|}{ Family Members } & \multirow{2}{*}{$\begin{array}{c}\text { Return } \\
\text { Date }\end{array}$} \\
\hline & \begin{tabular}{|c|} 
Name \\
\end{tabular} & Father's N. & Wife & Son & Daughter & Sister & Brother & Total & \\
\hline 1 & Mohd Hashem & Ali Juma & 1 & 3 & & & & 5 & 1994 \\
\hline 2 & Taj Mohd & Ali Juma & 1 & 2 & 4 & & & 8 & 1994 \\
\hline 3 & Khalifa Merza & Zli Dad & 1 & & & & & 2 & 1994 \\
\hline 4 & Musa & Mohd Esmail & 1 & 3 & 3 & & & 8 & 1994 \\
\hline 5 & Yahya & Musa & 1 & & 1 & & & 3 & 1994 \\
\hline 6 & Eshaq & Sultan & 1 & 1 & 1 & & & 4 & 1994 \\
\hline 7 & \begin{tabular}{|l|} 
Haidar \\
\end{tabular} & Asadullah & 1 & 3 & 3 & & & 8 & 1994 \\
\hline 8 & Said Asadullah & Said Mohd & 1 & 4 & 1 & & & 7 & 1994 \\
\hline 9 & Ghualam Abbas & Amir & 1 & 1 & 1 & & 1 & 5 & 1994 \\
\hline 10 & Ghulam Ali & Ali mohd & 1 & 1 & 2 & & & 5 & 1994 \\
\hline 11 & Ghulam Hussain & Ewaz & 1 & & 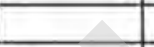 & 1 & 1 & 4 & 1994 \\
\hline 12 & Safdar & Khair Mohd & 1 & 3 & 2 & & & 7 & 1994 \\
\hline 13 & Haji Ewaz & Akhtar Mohd & 1 & & & - & & 2 & 1994 \\
\hline 14 & Muhammad & Hassan & 1 & 1 & 2 & & & 5 & 1994 \\
\hline 15 & Aurban & & 1 & 3 & 4 & & & 9 & 1994 \\
\hline 16 & Esmail & Hassan & 1 & 2 & 5 & & & 9 & 1994 \\
\hline 17 & Sakhidad & Bazo & 1 & 3 & 2 & $2=$ & & 7 & 1994 \\
\hline 18 & Ali Ram & Khudi Rahm & 1 & 3 & 2 & - & & 7 & 1994 \\
\hline 19 & Mulla Hussain & Mohd Ali & 1 & & & & & 2 & 1994 \\
\hline 20 & Najib's Mother & Hassan & & 5 & 2 & & & 8 & 1994 \\
\hline \multicolumn{3}{|c|}{ Total } & 19 & 38 & 35 & 1 & 2 & 115 & \\
\hline
\end{tabular}




\section{List of Returnees from Neighboring Countries}

Province: Balkh

District: Dawlatabad

Village: $\underline{\text { Durman }}$

\begin{tabular}{|c|c|c|c|c|c|c|c|c|c|}
\hline \multirow{2}{*}{$\begin{array}{c}\text { Serial } \\
\text { No }\end{array}$} & \multicolumn{2}{|c|}{ Identification } & \multicolumn{6}{|c|}{ Family Members } & \multirow{2}{*}{$\begin{array}{l}\text { Return } \\
\text { Date }\end{array}$} \\
\hline & Name & Father's N. & Wife & Son & Daughter & Sister & Brother & Total & \\
\hline 1 & Qurban & Haidar & 1 & 4 & \begin{tabular}{r|}
2 \\
\end{tabular} & & & 8 & 1994 \\
\hline 2 & Safdar & Haidar & 1 & 2 & & & & 4 & 1994 \\
\hline 3 & Qurban Ali & Mohd Rahim & 1 & 3 & 3 & & & 8 & 1994 \\
\hline 4 & Ghulam Hazrat & Ghulam Hussain & 1 & 2 & 1 & & & 5 & 1994 \\
\hline 5 & Enayat & Khalifa Abdul & 1 & 1 & 2 & & & 5 & 1994 \\
\hline 6 & Kabir & Khalifa Abdul & 1 & 2 & & & 1 & 5 & 1994 \\
\hline 7 & Ewaz & Mohammad & 1 & 3 & 2 & 2 & & 9 & 1994 \\
\hline 8 & Hussain Ali & Mohd Hussai & 1 & 2 & 1 & & & 5 & 1994 \\
\hline 9 & Khuda Bakhsh & Khuda Dad & 1 & 6 & 4 & & & 12 & 1994 \\
\hline 10 & Mohd Esa & Ghulam Ali & 1 & 2 & & & & 4 & 1994 \\
\hline 11 & Mohd Ali & Ebrahim & 1 & & + & & 1 & 3 & 1994 \\
\hline 12 & Ebrahim & Zawar & 1 & & 4 & & & 6 & 1994 \\
\hline 13 & Lal Mohd & Said Mohd & 1 & 3 & 2 & & & 7 & 1994 \\
\hline 14 & Mohd Esa & Said Mohd & 1 & 2 & 1 & & & 5 & 1994 \\
\hline 15 & Said Khaleqi & & 1 & 2 & 2 & & & 6 & 1994 \\
\hline 16 & Sarwar & Haidar & 1 & 1 & & & & 3 & 1994 \\
\hline 17 & Nazar & Haidar & 1 & & & I & & 2 & 1994 \\
\hline 18 & Sakhidad & Aurban & 1 & & 2 & 2 & 2 & 6 & 1994 \\
\hline 19 & Murad & Naeb & 1 & 3 & 2 & & & 7 & 1994 \\
\hline \multicolumn{3}{|c|}{ Total } & 19 & 38 & 28 & 2 & 4 & 110 & \\
\hline
\end{tabular}


List of Returnees from Neighboring Countries

Province: Balkh

District: Dawlatabad

Village: Asyabad

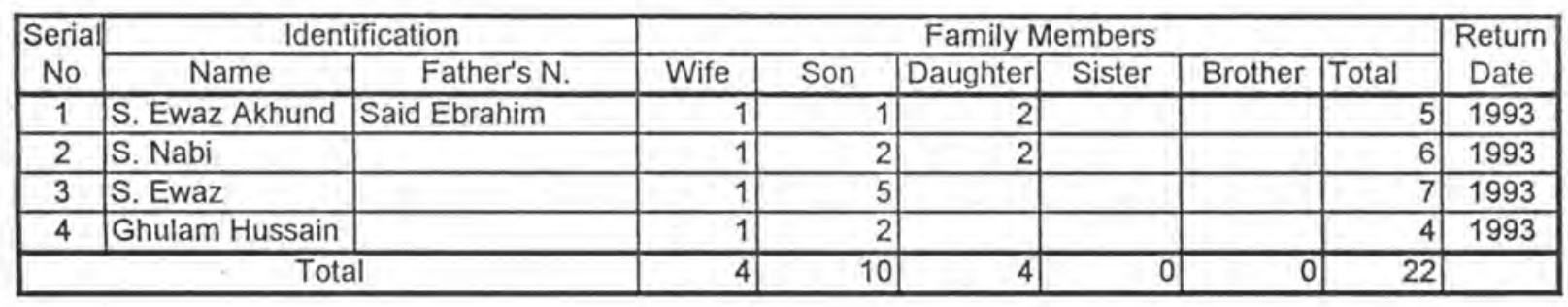




\section{List of Returnees from Neighboring Countries}

Province: Balkh

District: Dawlatabad

Village: Nawagil

\begin{tabular}{|c|c|c|c|c|c|c|c|c|c|}
\hline \multirow{2}{*}{$\begin{array}{c}\text { Serial } \\
\text { No }\end{array}$} & \multicolumn{2}{|c|}{ Identification } & \multicolumn{6}{|c|}{ Family Members } & \multirow{2}{*}{$\begin{array}{c}\text { Return } \\
\text { Date }\end{array}$} \\
\hline & Name & Father's N. & Wife & Son & Daughter & Sister & Brother & Total & \\
\hline 1 & Ahmad Shah & & 1 & 3 & 2 & & & 7 & 1993 \\
\hline 2 & Haidar Shah & & 1 & 1 & & & & 3 & 1993 \\
\hline 3 & Anwar & Haidar & 1 & 2 & 3 & & & 7 & 1993 \\
\hline 4 & Muhammad & & 1 & 3 & 4 & & & 9 & 1993 \\
\hline 5 & Shir Ali & & 1 & 2 & 3 & & & 7 & 1993 \\
\hline 6 & Ghulam Haidar & & 1 & 2 & 2 & & & 6 & 1993 \\
\hline 7 & Said Khudadad & & 1 & 4 & 4 & & & 10 & 1993 \\
\hline 8 & Said Hassan & Said Ewaz & 1 & 1 & & 1 & & 4 & 1993 \\
\hline 9 & Ghulam Ali & & 1 & 3 & 3 & & & 8 & 1993 \\
\hline 10 & Mulla Sultan & & 1 & & & & & 2 & 1993 \\
\hline \multicolumn{3}{|c|}{ Total } & 10 & 21 & 21 & 1 & 0 & 63 & \\
\hline
\end{tabular}




\section{List of Returnees from Neighboring Countries}

Province: Balkh

District: Dawlatabad

Village: Sarasya

\begin{tabular}{|c|c|c|c|c|c|c|c|c|c|}
\hline \multirow{2}{*}{$\begin{array}{c}\text { Serial } \\
\text { No }\end{array}$} & \multicolumn{2}{|c|}{ Identification } & \multicolumn{6}{|c|}{ Family Members } & \multirow{2}{*}{$\begin{array}{c}\text { Return } \\
\text { Date }\end{array}$} \\
\hline & Name & Father's N. & Wife & Son & Daughter & Sister & Brother & Total & \\
\hline \begin{tabular}{l|l}
1 \\
\end{tabular} & Laeq & Ewaz & 1 & 2 & 1 & & 1 & 6 & 1995 \\
\hline 2 & Hussain Ali & Ewaz & 1 & 1 & & & & 3 & 1995 \\
\hline 3 & Ali Hussain & & & 1 & 1 & & & 3 & 1995 \\
\hline 4 & Mubarez & & 1 & & & & & 2 & 1995 \\
\hline 5 & Mulla Sarwar & & 1 & & & & & 2 & 1995 \\
\hline 6 & Tgqi & & 1 & 2 & 2 & & & 6 & 1995 \\
\hline 7 & Mohd Ali & Qasem & 1 & 2 & 4 & & & 8 & 1995 \\
\hline 8 & Abdul & Raoof & 1 & 1 & & & 2 & 5 & 1995 \\
\hline 9 & Ghulam Haidar & Yosuf & 1 & 2 & & & 5 & 9 & 1995 \\
\hline \multicolumn{3}{|c|}{$\begin{array}{c}\text { Total } \\
\end{array}$} & 8 & 11 & 8 & 0 & 8 & 44 & \\
\hline
\end{tabular}




\section{List of Returnees from Neighboring Countries}

Province: Balkh

District: Dawlatabad

Village: Qara Uila

\begin{tabular}{|c|c|c|c|c|c|c|c|c|c|}
\hline \multirow{2}{*}{$\begin{array}{c}\text { Serial } \\
\text { No }\end{array}$} & \multicolumn{2}{|c|}{ Identification } & \multicolumn{6}{|c|}{ Family Members } & \multirow{2}{*}{$\begin{array}{l}\text { Return } \\
\text { Date } \\
\end{array}$} \\
\hline & Name & Father's N. & Wife & Son & Daughter & Sister & Brother & Total & \\
\hline 1 & Khudidad & & 1 & 2 & 2 & & 1 & 7 & 1994 \\
\hline 2 & Shaikh Ghulam & Ghulam Haidar & 1 & 1 & 2 & & & 5 & 1994 \\
\hline 3 & Ghulam Mohd & Hussain & 1 & 3 & 3 & & & 8 & 1994 \\
\hline 4 & Ghulam Abbas & & 1 & 1 & & & & 3 & 1994 \\
\hline 5 & Nezam & Ghulam Hussain & 1 & 1 & 6 & & 1 & 10 & 1994 \\
\hline 6 & Ghulam Ali & Ghulam Rasol & 1 & 2 & & & 1 & 5 & 1994 \\
\hline 7 & Haji Musa & Mulla G. Haidar & 1 & 2 & & & & 4 & 1994 \\
\hline 8 & Ghulam Reza & Haji Musa & 1 & 6 & 2 & & & 10 & 1994 \\
\hline 9 & Ghulam haidar & & 1 & 6 & 2 & & & 10 & 1994 \\
\hline 10 & Abbas & & 1 & 3 & 3 & & & 8 & 1994 \\
\hline 11 & Mirullah & Haji Safar & 1 & 1 & 2 & & & 5 & 1994 \\
\hline 12 & Anwar & Ghulam Haidar & 1 & 4 & 1 & & & 7 & 1994 \\
\hline 13 & Muhammad & Aslo & 1 & 3 & 2 & & & 7 & 1994 \\
\hline 14 & Ghulam Rasul & Juma Ali & 1 & 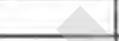 & 4 & & & 2 & 1994 \\
\hline 15 & Nader & Mukhtar & 1 & 3 & 2 & & & 7 & 1994 \\
\hline 16 & Haji Mukhtar & & 1 & & & & & 2 & 1994 \\
\hline 17 & Amin & & 1 & 3 & 2 & & & 7 & 1994 \\
\hline 18 & Gulmurad & & 1 & & 2 & & & 4 & 1994 \\
\hline 19 & Ghulam Ali & Nabi & 1 & 3 & 4 & & & 9 & 1994 \\
\hline 20 & Ghulam Hussain & Ghulam Ali & 1 & 1. & $\square$ & & & 3 & 1994 \\
\hline 21 & Haidar & Najaf & 1 & 5 & 2 & & & 9 & 1994 \\
\hline 22 & Habib & Najaf & 1 & 1 & 1 & & & 4 & 1994 \\
\hline 23 & Ibrahim & Sokhti & 1 & 2 & 1 & & & 5 & 1994 \\
\hline 24 & Eshaq & Ibrahim & 1 & 3 & 2 & & & 7 & 1994 \\
\hline 25 & Nabi & Ghulam Ali & 1 & 1 & 1 & & & 4 & 1994 \\
\hline 26 & Said Mubarez & Said Hassan & 1 & 7 & 1 & & & 10 & 1994 \\
\hline 27 & Said Balkhabi & 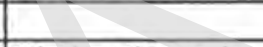 & 1 & 1 & 1 & & & 4 & 1994 \\
\hline 28 & Mohd Ali & Ghulam Hussain & 1 & 2 & 5 & & & 9 & 1994 \\
\hline 29 & Barat & Yaqub & 1 & 2 & 1 & & & 5 & 1994 \\
\hline 30 & Hussain & Aati & 1 & 3 & 4 & & & 9 & 1994 \\
\hline \multicolumn{3}{|c|}{ Total } & 30 & 72 & 54 & 이 & 3 & 189 & \\
\hline
\end{tabular}




\section{List of Returnees from Neighboring Countries}

Province: Balkh

District: Dawlatabad

Village: Charbahg-e-Saidan

\begin{tabular}{|c|c|c|c|c|c|c|c|c|c|}
\hline \multirow{2}{*}{$\begin{array}{c}\text { Serial } \\
\text { No }\end{array}$} & \multicolumn{2}{|c|}{ Identification } & \multicolumn{6}{|c|}{ Family Members } & \multirow{2}{*}{$\begin{array}{c}\text { Return } \\
\text { Date }\end{array}$} \\
\hline & \begin{tabular}{|c|} 
Name \\
\end{tabular} & Father's N. & Wife & Son & Daughter & Sister & Brother & Total & \\
\hline 1 & Ghulam & Ghulam Haidar & 1 & 3 & 1 & & & 6 & 1994 \\
\hline 2 & Khudai Dad & Ghulam & 1 & 2 & 3 & & & 7 & 1994 \\
\hline 3 & Abdul Aziz & Esmail & 1 & 4 & 2 & & & 8 & 1994 \\
\hline 4 & Enayat & Ewaz & 1 & 2 & 2 & & & 6 & 1994 \\
\hline 5 & \begin{tabular}{|l} 
Muhammad \\
\end{tabular} & Ewaz & 1 & 2 & 1 & & & 5 & 1994 \\
\hline 6 & Gul Muhammad & Ewaz & & & & 2 & 1 & 4 & 1994 \\
\hline 7 & Ahmad & Nazar Mohd & 1 & 2 & 2 & & & 6 & 1994 \\
\hline 8 & Mohd Hasan & Mohd Esa & 1 & 3 & 2 & & & 7 & 1994 \\
\hline 9 & Mohd Esa & Muhammad & 1 & & & & & 2 & 1994 \\
\hline 10 & Mohd Eshaq & Mohd Esa & 1 & 2 & 4 & & & 8 & 1994 \\
\hline 11 & Mohd Juma & Mohd Esa & 1 & & & & & 2 & 1994 \\
\hline 12 & Ghulam Hussain & Ali Juma & 1 & 1 & & & & 3 & 1994 \\
\hline 13 & Mohd Yosuf & Afghan & 1 & & $\theta$ & & & 2 & 1994 \\
\hline 14 & \begin{tabular}{|l} 
Juma Khan \\
\end{tabular} & Dad Ali & 1 & 1 & 1 & & & 4 & 1994 \\
\hline 15 & Aziz & Amir Mohd & 1 & + & - & & & 2 & 1994 \\
\hline 16 & Ghulam Hussain & Ghulam Haidar & 1 & 2 & 3 & & & 7 & 1994 \\
\hline 17 & Rasul & Barat & 1 & 1 & 3 & & & 6 & 1994 \\
\hline 18 & Abbas & Rasul & 1 & 2 & 1 & & & 5 & 1994 \\
\hline 19 & Sarwar & Rasul & 1 & 1 & 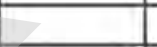 & & & 3 & 1994 \\
\hline 20 & Ibrahim & Mohd Esa & 1 & 1 & 1 & 1 & 1 & 6 & 1994 \\
\hline 21 & Sarwar & Ghlam Hussain & 1 & 2 & 2 & & & 6 & 1994 \\
\hline 22 & Mirza Hussain & Sarwar & 1 & 1 & 2 & & & 5 & 1994 \\
\hline 23 & Qurban Ali & Ghulam Ali & 1 & 1 & 1 & & 1 & 5 & 1994 \\
\hline 24 & Sarwar & Khudai Dad & 1 & & & 2 & 1 & 5 & 1994 \\
\hline 25 & Hussain & Qurban & 1 & 2 & 2 & & & 6 & 1994 \\
\hline 26 & Muhammad Esa & Khuda Dad & 1 & 2 & 2 & & & 6 & 1994 \\
\hline 27 & Mohd Ali & Ghulam Hussain & 1 & 1 & 2 & & & 5 & 1994 \\
\hline 28 & Hussai & Ghulam Hussain & 1 & 2 & 3 & & & 7 & 1994 \\
\hline 29 & Muhsen & Alidad & 1 & 4 & 3 & & & 9 & 1994 \\
\hline 30 & Ghulam Sakhi & Alidad & 1 & 2 & 3 & & & 7 & 1994 \\
\hline 31 & Ghulam Haidar & Alidad & 1 & 2 & 2 & & & 6 & 1994 \\
\hline 32 & Hussain Qul & Ahmad & 1 & 1 & 1 & & & 4 & 1994 \\
\hline 33 & Said Ahmad & S Nur Agha & 1 & 3 & 2 & & & 7 & 1994 \\
\hline 34 & S, Ghulam Sakhi & S Musa & 1 & 2 & 3 & & & 7 & 1994 \\
\hline 35 & Ali Mohd & Akbar & 1 & 1 & 1 & 1 & 1 & 6 & 1994 \\
\hline 36 & Amin & Aziz & 1 & 2 & 1 & & & 5 & 1994 \\
\hline 37 & Hussain Ali & Ghulam Ali & 1 & 1 & 1 & & & 4 & 1994 \\
\hline 38 & Khalifa G. Hassan & & 1 & 2 & 2 & & & 6 & 1994 \\
\hline 39 & Ghulam Nabi & Faqir Mohd & 1 & 2 & 1 & & & 5 & 1994 \\
\hline 40 & Khalifa Eshaq & Haji Ibrahim & 1 & 1 & 1 & & & 4 & 1994 \\
\hline 41 & Mohd Ali & Eshaq & 1 & 1 & 1 & & & 4 & 1994 \\
\hline
\end{tabular}




\begin{tabular}{|c|c|c|c|c|c|c|c|c|c|}
\hline 42 & Hassan Ali & Qurban & 1 & 2 & 1 & & & 5 & 1994 \\
\hline 43 & Abdullah & Ghulam Hussain & 1 & 3 & 3 & & & 8 & 1994 \\
\hline 44 & Hassan Agha & Ghulam Ali & 1 & 2 & 2 & & & 6 & 1994 \\
\hline 45 & Said Yahya & Said Askar & 1 & 1 & 1 & & & 4 & 1994 \\
\hline 46 & Said Mohd & & 1 & & 2 & & & 4 & 1994 \\
\hline 47 & Barat & Mohd Dad & 1 & 4 & 2 & & & 8 & 1994 \\
\hline 48 & Ghulam Abbas & Ghulam & & & & 2 & 2 & 5 & 1994 \\
\hline 49 & Ali Akbar & Hussain Ali & 1 & 1 & 1 & & & 4 & 1994 \\
\hline 50 & Mohd Ibrahim & & & 2 & 1 & & & 4 & 1994 \\
\hline 51 & Jafar & Ibrahim & & & & & 3 & 4 & 1994 \\
\hline 52 & Shir Ali & Khan Ali & 1 & & & 2 & 1 & 5 & 1994 \\
\hline 53 & Mohd Hassan & Hussain & & & & 3 & 3 & 7 & 1994 \\
\hline 54 & Tella Hussain & Abdullah & 1 & 3 & 3 & & & 8 & 1994 \\
\hline 55 & Mohd Esa & & & 1 & 2 & & & 4 & 1994 \\
\hline 56 & Qurban Karbalai & Aildy & 1 & 2 & 3 & & & 7 & 1994 \\
\hline \multicolumn{3}{|c|}{$\begin{array}{r}\text { Total } \\
\end{array}$} & 50 & 85 & 83 & 13 & 14 & 301 & \\
\hline
\end{tabular}




\section{List of Returnees from Neighboring Countries}

Province: Balkh

District: Dawlatabad

Village: Sar Deh

\begin{tabular}{|c|c|c|c|c|c|c|c|c|c|}
\hline \multirow{2}{*}{$\begin{array}{c}\text { Serial } \\
\text { No }\end{array}$} & \multicolumn{2}{|c|}{ Identification } & \multicolumn{6}{|c|}{ Family Members } & \multirow{2}{*}{$\begin{array}{c}\text { Retum } \\
\text { Date }\end{array}$} \\
\hline & Name & Father's N. & Wife & Son & Daughter & Sister & Brother & Total & \\
\hline \begin{tabular}{|l|}
1 \\
\end{tabular} & Shaikh Hssan & Haji Musa & 1 & 2 & 2 & & & 6 & 1993 \\
\hline 2 & Mohd Baqer & & 1 & 1 & 1 & & & 4 & 1993 \\
\hline 3 & Nabi & Mohd Jan & 1 & 2 & 3 & & & 7 & 1993 \\
\hline 4 & Ghulam Hussain & Haji Musa & 1 & 1 & 2 & 1 & & 6 & 1993 \\
\hline 5 & Ghulam Sakhi & Khair Mohd & 1 & 2 & 2 & & & 6 & 1993 \\
\hline 6 & M Habibullah & Ali Akbar & 1 & 3 & 4 & & & 9 & 1993 \\
\hline 7 & Mohd Taher & Mohd Musa & 1 & 3 & 2 & & & 7 & 1993 \\
\hline 8 & Rustam & Abdul Rahman & 1 & 2 & 4 & & & 8 & 1993 \\
\hline 9 & Reza Dad & Khudai Dad & 1 & 1 & 4 & & & 7 & 1993 \\
\hline 10 & Raza & Sadeq & 1 & 2 & 1 & & & 5 & 1993 \\
\hline 11 & Ghulam Abbas & & 1 & 1 & 1 & & & 4 & 1993 \\
\hline 12 & Hsan & & 1 & & 2 & 1 & & 5 & 1993 \\
\hline 13 & Ghulam Sakhi & Panah & 1 & 2 & 2 & & & 6 & 1993 \\
\hline 14 & Asghar & Ghulam Sakhi & 1 & 3 & 4 & & & 9 & 1993 \\
\hline 15 & Ghulam Nabi & Ghulam Sakhi & 1 & 2 & 7 & & & 4 & 1993 \\
\hline 16 & Abdul Hadi & Ghulam Sakhi & 1 & 3 & 1) & & & 6 & 1993 \\
\hline 17 & Ghulam Haidar & Mohd Haidar & 1 & 4 & 1. & & & 7 & 1993 \\
\hline 18 & Ghula; Hassan & Mohd Haidar & 1 & 2 & 1 & & & 5 & 1993 \\
\hline 19 & Mohd Hashem' & Hussain & 1 & 2 & 2 & & & 6 & 1993 \\
\hline 20 & Ghulam Raza & Hussain & 1 & 4 & 1 & & & 7 & 1993 \\
\hline 21 & Mohammad & Haji Musa & 1 & 4 & 2 & & & 8 & 1993 \\
\hline 22 & Qshaq & Ghulam & 1 & 2 & 2 & 1 & & 7 & 1993 \\
\hline 23 & S Ghulam Ali & Said Adina & 1 & 3 & 2 & & & 7 & 1993 \\
\hline 24 & Ali Dad & Mohd Esa & 1 & 2 & 1 & & & 5 & 1993 \\
\hline 25 & Hussain Dad & Alidad & 1 & 1 & 1 & & & 4 & 1993 \\
\hline 26 & Yaqub & Nabi & 1 & 2 & 2 & & & 6 & 1993 \\
\hline 27 & Noor Ali & Adel Zawar & 1 & 3 & 2 & & & 7 & 1993 \\
\hline 28 & Haidar & Reza & 1 & 2 & 3 & 1 & & 8 & 1993 \\
\hline 29 & Ibrahim & Mohd Esa & 1 & 1 & 1 & & & 4 & 1993 \\
\hline 30 & Ghulam Nabi & Ghulam Hasan & 1 & 1 & 4 & 1 & & 8 & 1993 \\
\hline 31 & S Mohd Ali & Said Akbar & 1 & 2 & 2 & & & 6 & 1993 \\
\hline 32 & Daud & Hkudaidad & 1 & 3 & 1 & & & 6 & 1993 \\
\hline 33 & Mohd Anwar & Mohd Sarwar & 1 & 4 & 2 & & & 8 & 1993 \\
\hline 34 & Muhammad & Nazar Chak Bashi & 1 & 3 & 3 & & & 8 & 1993 \\
\hline 35 & Hussain & Nazar Chak Bashi & 1 & 2 & 4 & & & 8 & 1993 \\
\hline 36 & Musa Chakbashi & Ghulam Ali & 1 & 4 & 5 & & & 11 & 1993 \\
\hline 37 & Khal Mohd & Usman & 1 & 3 & 3 & & & 8 & 1993 \\
\hline 38 & Said Muslem & Shah Murtaza & 1 & 2 & 2 & & & 6 & 1993 \\
\hline 39 & Said Ali & Said Muslem & 1 & 1 & 1 & & & 4 & 1993 \\
\hline 40 & Akram & Haidar & 1 & 3 & 1 & & & 6 & 1993 \\
\hline 41 & Mohd Ashraf & Mohd Anwar & 1 & 2 & 1 & & & 5 & 1993 \\
\hline
\end{tabular}




\begin{tabular}{|c|c|c|c|c|c|c|c|c|c|}
\hline 42 & Ghulam Reza & Ahmad Chak Bashi & 1 & 2 & 3 & & & 7 & 1993 \\
\hline 43 & Najibullah & Ghulam Reza & 1 & 3 & 3 & & & 8 & 1993 \\
\hline 44 & Cheragh Ali & Safar Dad & 1 & 2 & 2 & & & 6 & 1993 \\
\hline 45 & Khan Ali & Safar Dad & 1 & 2 & & & & 4 & 1993 \\
\hline 46 & Hamed & Mulla Musa & 1 & 3 & 1 & & & 6 & 1993 \\
\hline 47 & Mohd Yasin & Hamed & 1 & 2 & 2 & & & 6 & 1993 \\
\hline 48 & Qurban Ali & Haji Esmail & 1 & 3 & 2 & & & 7 & 1993 \\
\hline 49 & Ghula Haidar & Karim & 1 & 2 & 2 & & & 6 & 1993 \\
\hline 50 & Haji Basir & Ghulam Haidar & 1 & 1 & & & & 3 & 1993 \\
\hline 51 & Ghulam Abbas & Ahmad Chak Bashi & 1 & 2 & 3 & & & 7 & 1993 \\
\hline 52 & Sufi Noor Ali & & 1 & 1 & 1 & & & 4 & 1993 \\
\hline 53 & Mohd Sharif & Nawroz & 1 & 2 & 1 & & & 5 & 1993 \\
\hline 54 & Abdul Wahed & Nawroz & 1 & 1 & 3 & & & 6 & 1993 \\
\hline 55 & Haji Safar & Mukhtar & 1 & 2 & 2 & & & 6 & 1993 \\
\hline 56 & Hayatullah & Mohd Jan & 1 & 2 & & 2 & & 6 & 1993 \\
\hline \multicolumn{3}{|c|}{ Total } & 56 & 122 & 110 & 7 & 이 & 351 & \\
\hline
\end{tabular}




\section{List of Returnees from Neighboring Countries}

Province: Balkh

District: Dawlatabad

Village: Paay Mashhad

\begin{tabular}{|c|c|c|c|c|c|c|c|c|c|}
\hline \multirow{2}{*}{\begin{tabular}{|c|} 
Serial \\
No
\end{tabular}} & \multicolumn{2}{|c|}{ Identification } & \multicolumn{6}{|c|}{ Family Members } & \multirow{2}{*}{$\begin{array}{c}\text { Return } \\
\text { Date }\end{array}$} \\
\hline & Name & Father's N. & Wife & Son & Daughter & Sister & Brother & Total & \\
\hline 1 & Ghulam Mohd & Nabi & 1 & 5 & 1 & & & 8 & 1994 \\
\hline 2 & Mohd Nazir & Mohd Nawroz & 1 & 4 & 1 & & & 7 & 1994 \\
\hline 3 & Abdul Azim & Abdul Ali & 1 & 2 & 2 & & & 6 & 1994 \\
\hline 4 & Ghulam Ali & Mohd Nabi & 1 & 2 & & & & 4 & 1994 \\
\hline 5 & Khan Ali & Nabi & 1 & & & & & 2 & 1994 \\
\hline 6 & Sawar & Ghulam Haidar & & & & 1 & 3 & 5 & 1994 \\
\hline 7 & Ghulam Nabi & Ghulam Hassan & 1 & 1 & & & & 3 & 1994 \\
\hline 8 & Ibrahim & Merza Hussain & 1 & 2 & 1 & & & 5 & 1994 \\
\hline 9 & Juma Khan & Mirza & 1 & 2 & & & & 4 & 1994 \\
\hline 10 & Ghafoor & Khudi Nazar & 1 & 3 & 2 & & & 7 & 1994 \\
\hline 11 & Chaman Ali & Sakhidad & 1 & 1 & 1 & & & 4 & 1994 \\
\hline 12 & Shir Ali & Ali Rhim & 1 & 1 & 1 & & & 4 & 1994 \\
\hline 13 & Said Mohd & Said Ibrahim & 2 & 2 & 3 & & & 8 & 1994 \\
\hline 14 & Mohd Ali & Esmail & 1 & 2 & 2 & & & 6 & 1994 \\
\hline 15 & Mohd Hussain & Ghulam Hussain & 1 & 1 & 1 & & & 4 & 1994 \\
\hline 16 & Mohd Qurban & Ghulam Hussain & 1 & $\rightarrow$ & 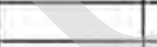 & & & 2 & 1994 \\
\hline 17 & Ghulam Rasul & Ghulam Nabi & 1 & 1 & 1 & 7 & & 4 & 1994 \\
\hline 18 & Abdul Wahab & Ghulam Sakhi & 1 & 6 & 2 & & & 10 & 1994 \\
\hline 19 & Ghulam Sakhi & Ali Gawhar & 1 & 1. & & & & 3 & 1994 \\
\hline 20 & Ghulam Yahya & Ghulam Sakhi & 1 & 2 & 2 & & & 6 & 1994 \\
\hline 21 & Ghulam Rasul & Mulla Nabi & 1 & 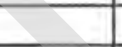 & 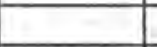 & 2 & & 4 & 1994 \\
\hline 22 & Mohd Hassan & Mohd Najaf & 1 & 2 & 2 & & & 6 & 1994 \\
\hline 23 & Mohd Rafi & Ghulam Ali & 1 & 2 & 3 & & & 7 & 1994 \\
\hline 24 & Muhsen & Dost Karbalai & 1 & 2 & 4 & & & 8 & 1994 \\
\hline 25 & Mohd Anwar & Mulla Ibrahim & 1 & 4 & 3 & & & 9 & 1994 \\
\hline 26 & Mohd Ibrahim & Esmail & 1 & 1 & & & & 3 & 1984 \\
\hline 27 & Roz Mohd & Mulla Hussain Baksh & 1 & 1 & 1 & & & 4 & 1994 \\
\hline 28 & Ghulam Abbas & Ali Mohd & & & & 1 & 2 & 4 & 1994 \\
\hline 29 & Payenda & Qurban Ali & 1 & 1 & & & & 3 & 1994 \\
\hline 30 & Musa & Manjar Ali & 1 & 2 & 1 & & & 5 & 1994 \\
\hline \multicolumn{3}{|c|}{ Total } & 29 & 53 & 34 & 4 & 5 & 155 & \\
\hline
\end{tabular}




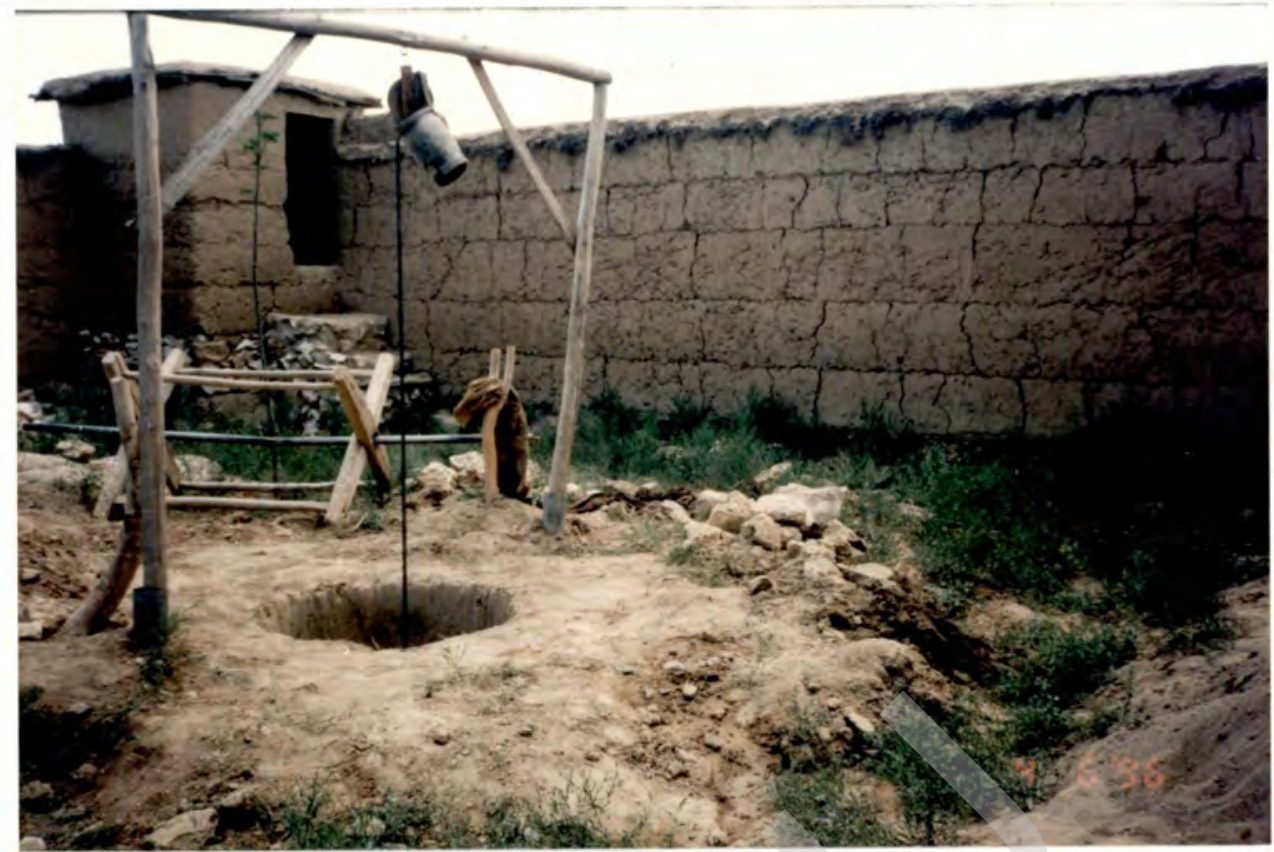

Open Wells and closed Unsafe Latrines cause Transmitting Diseases

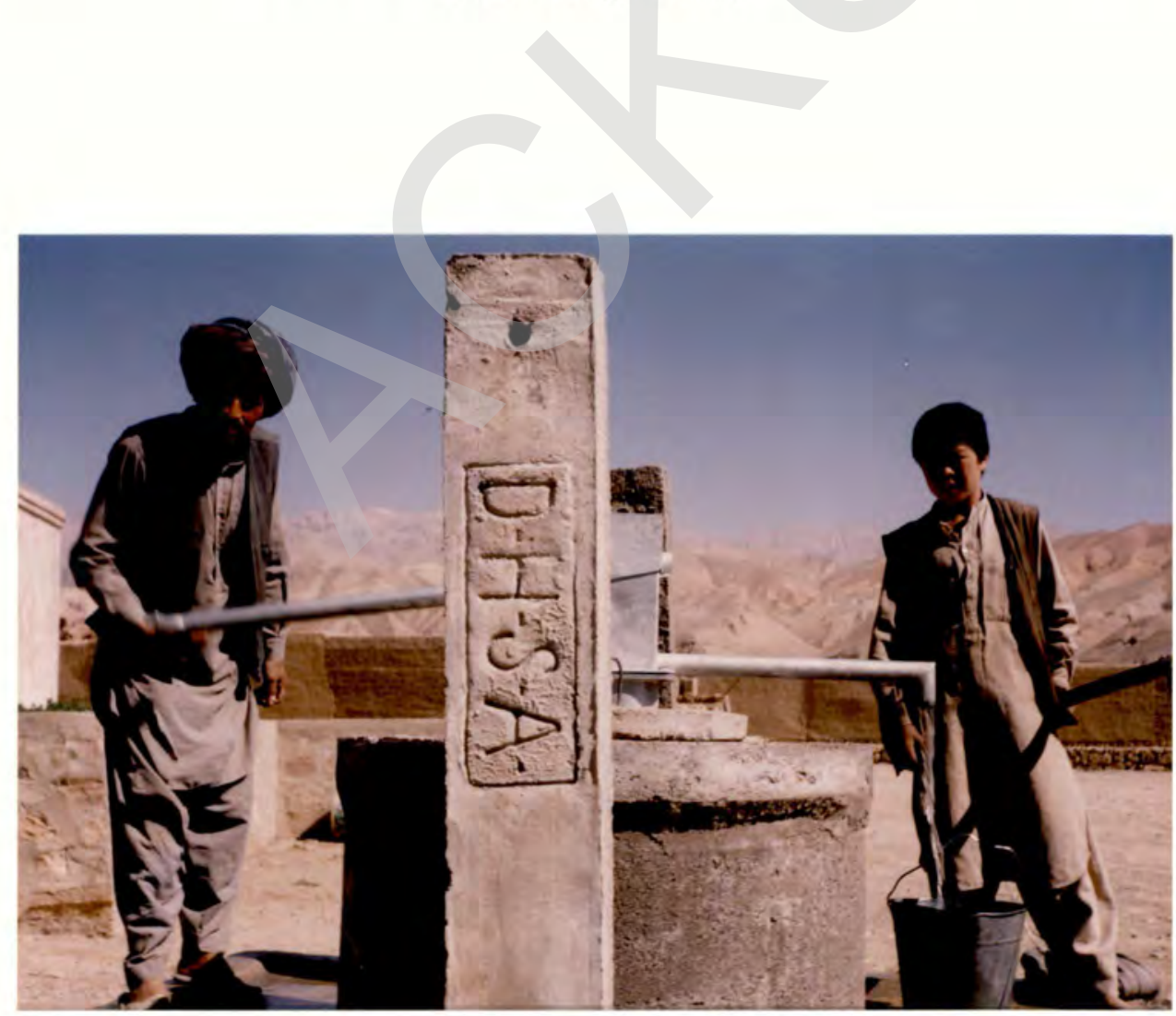

Wells equipped with Hand Pumps avoid its Contamination and makes access easier to Potable Water

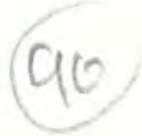




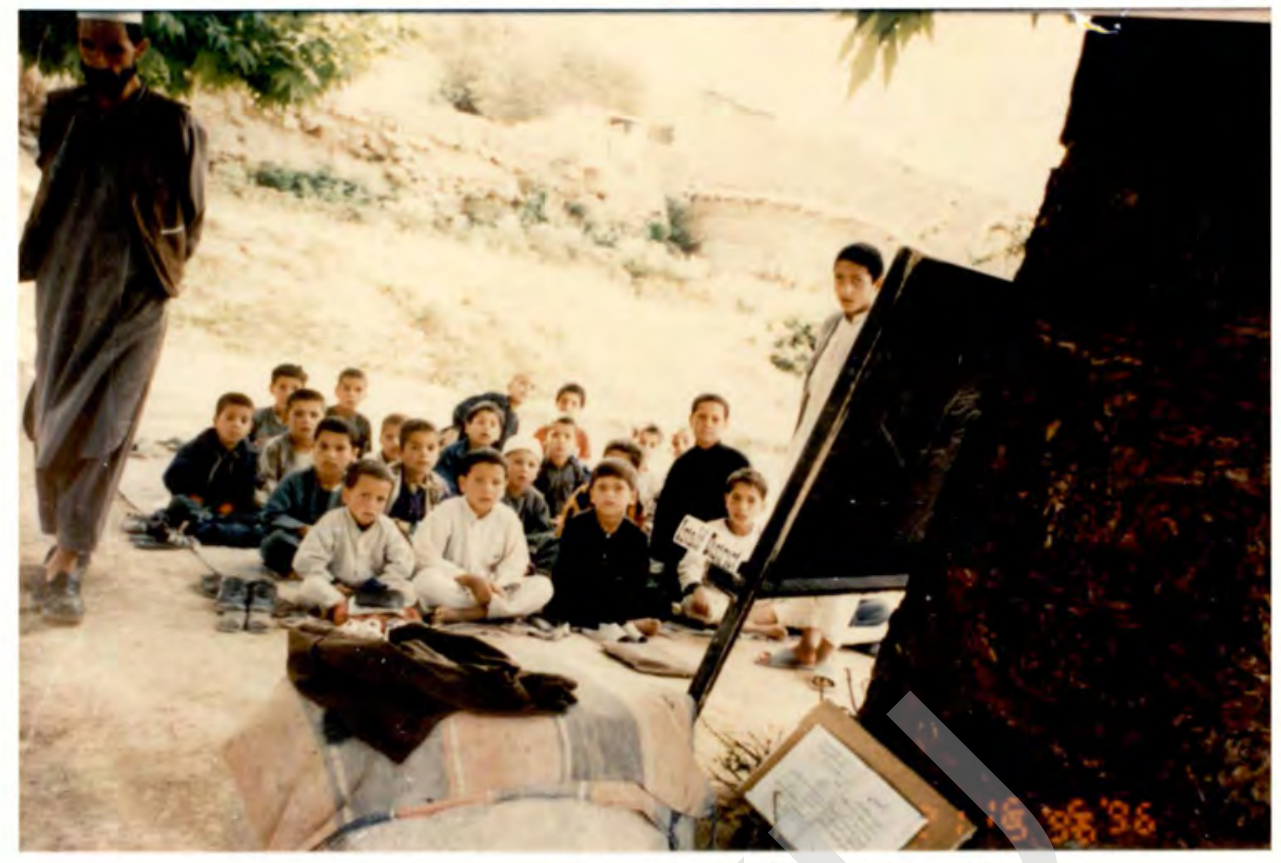

Sunshine, Dust and Cold Weather are harmful for children

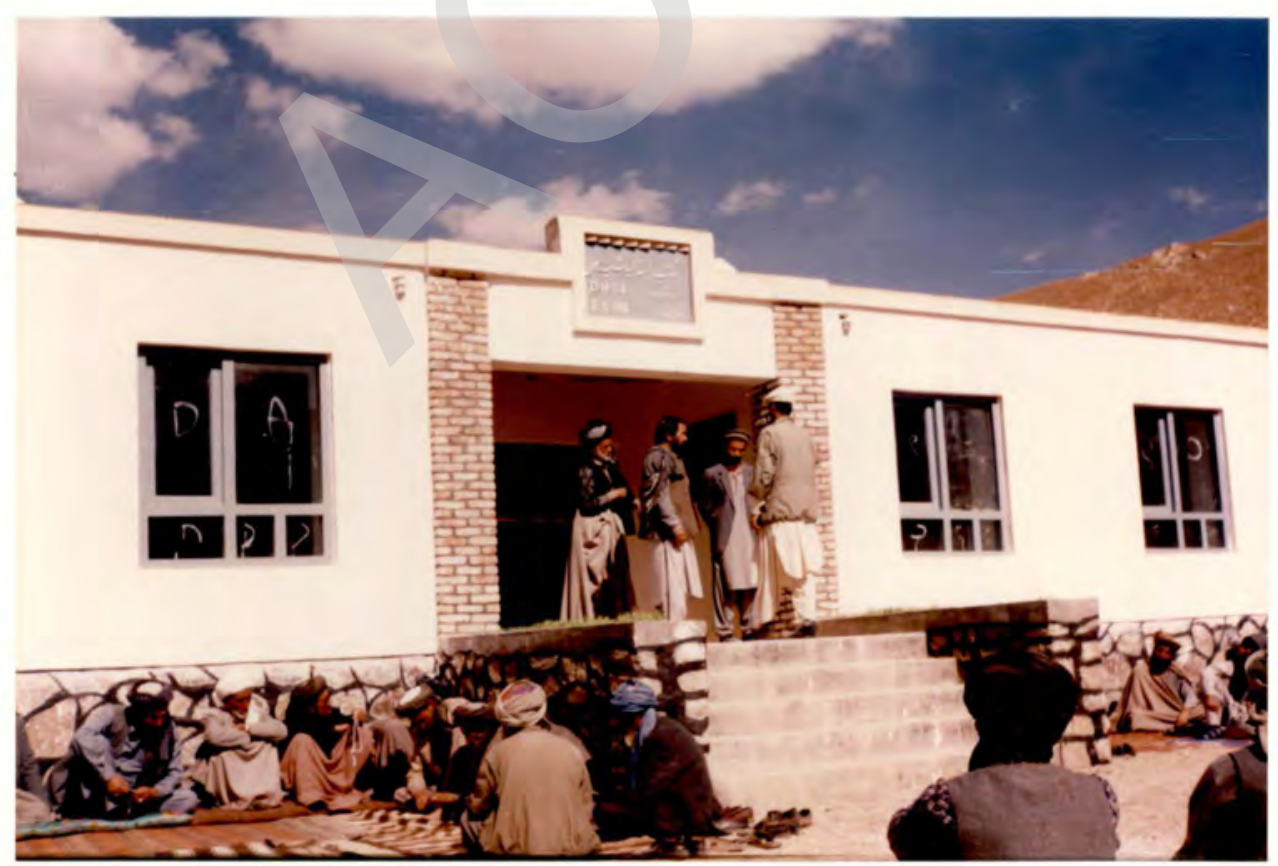

A School Building was constructed by DHSA in Jeghatu District of Ghazni Province and handed over to the community 


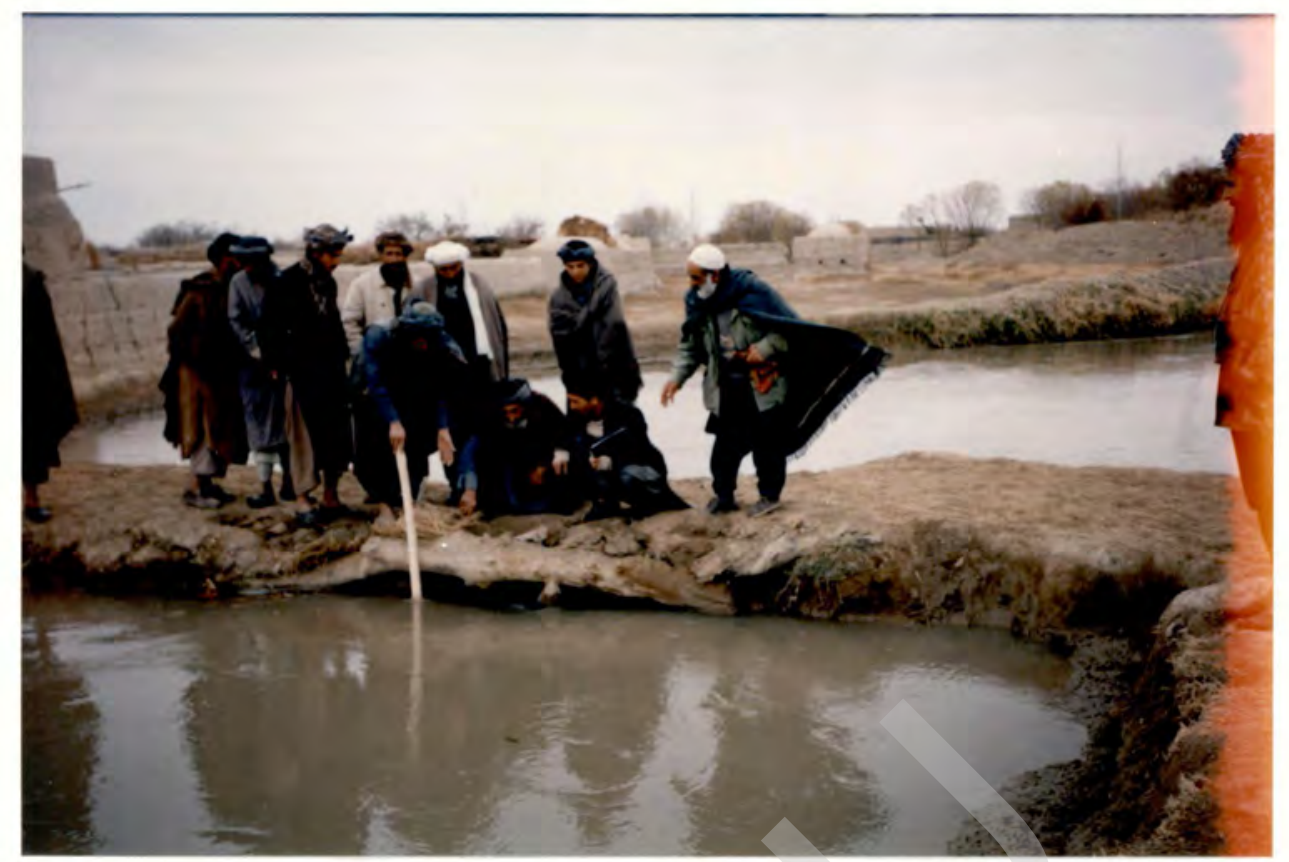

Traditional Made Culverts are destroyed by Excess Water and block Irrigation Channels

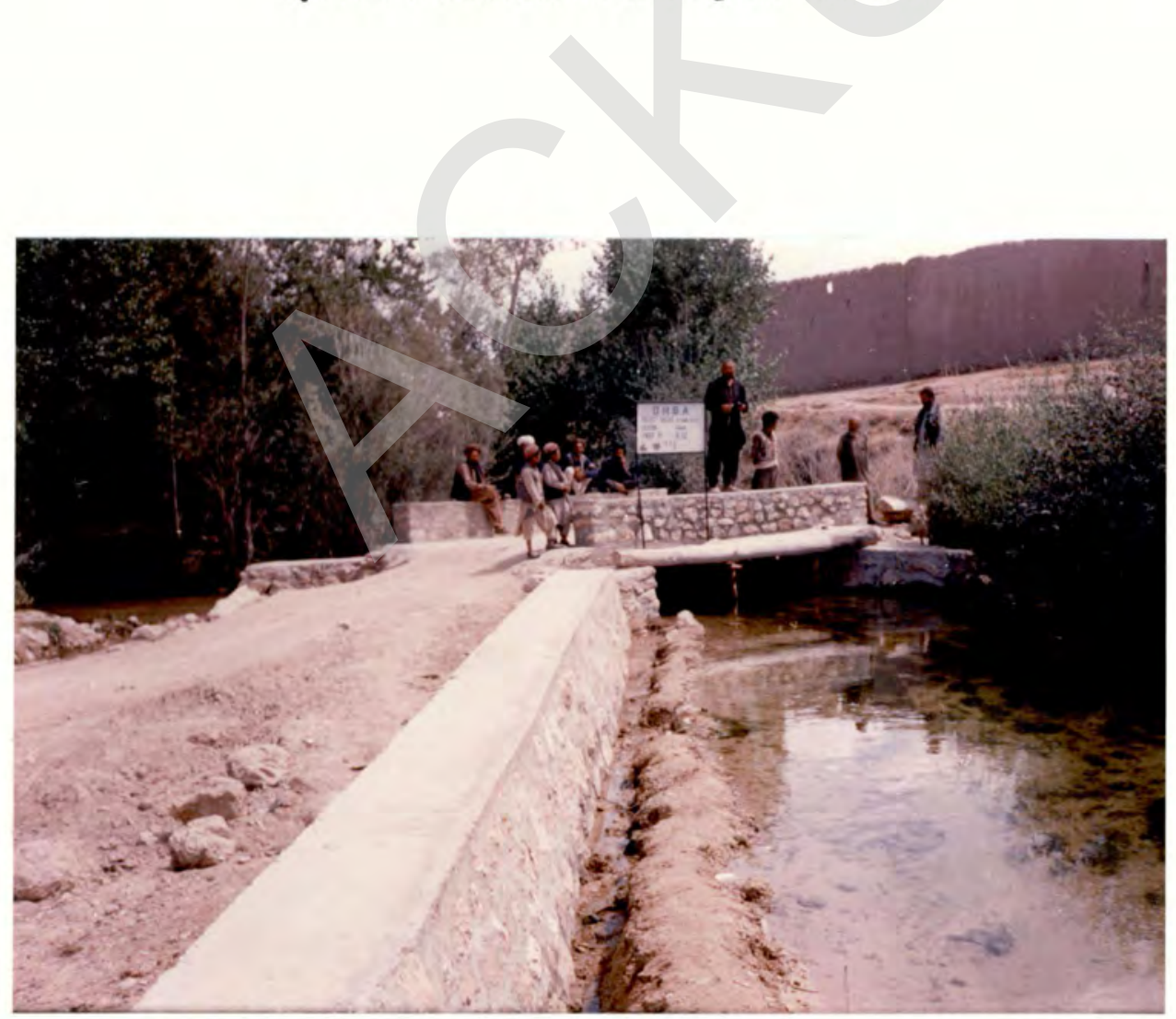

A Small Bridge constructed by DHSA in Nawor District of Ghazni Province

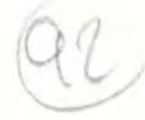




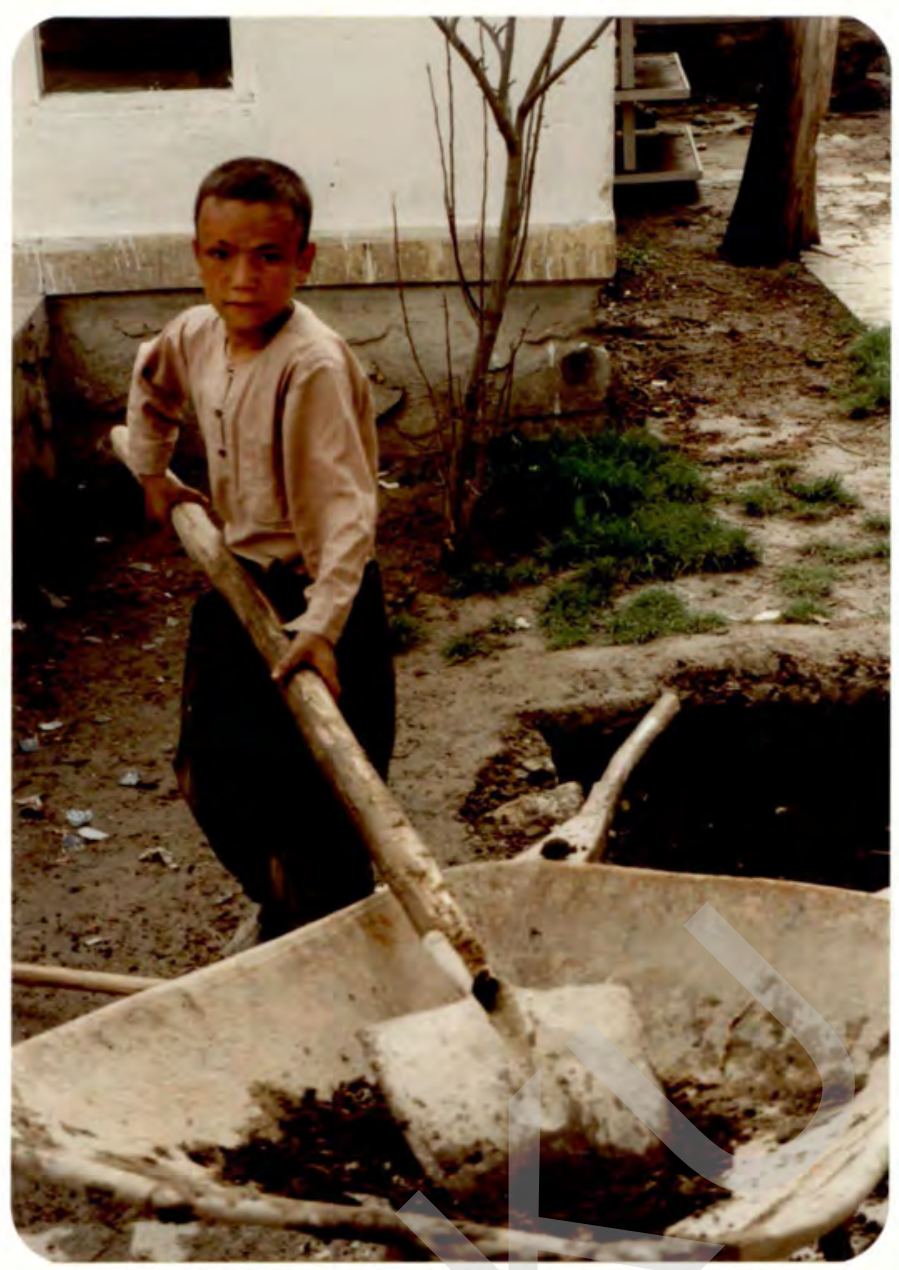

Most of the time, Street Children are being

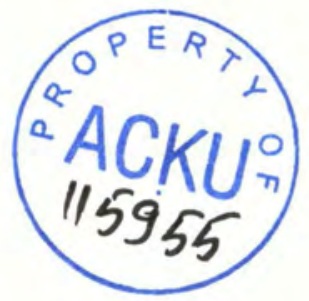
abused in the society

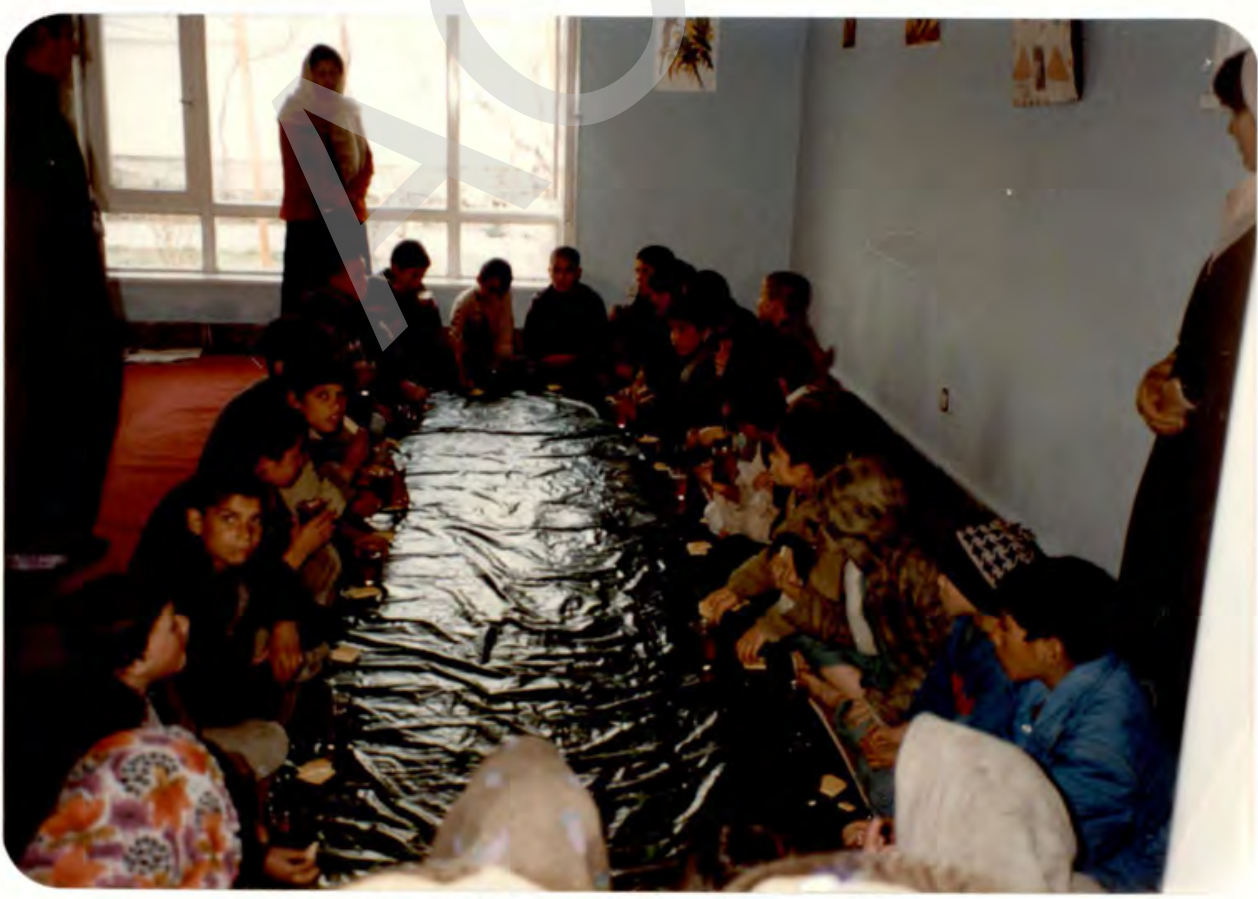

Street Children take a light breakfast

during reporting to the Ashiana

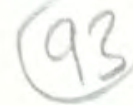

